\title{
A Life Cycle Assessment (LCA) of the potential for biofuels \\ to reduce greenhouse gas emissions and fossil fuel consumption: \\ Comparative assessment of two regions in Ontario, Canada
}

By Stewart Fast B.Sc. (Ag.), B.Sc

A thesis submitted to:

The Faculty of Graduate Studies and Research

In partial fulfillment of the requirements for the degree:

\author{
Master of Arts \\ Department of Geography and Environmental Studies \\ Carleton University
}

(C) Stewart Fast, 2008 


$\begin{array}{ll}\begin{array}{l}\text { Library and } \\ \text { Archives Canada }\end{array} & \begin{array}{l}\text { Bibliothèque et } \\ \text { Archives Canada }\end{array} \\ \begin{array}{l}\text { Published Heritage } \\ \text { Branch }\end{array} & \begin{array}{l}\text { Direction du } \\ \text { Patrimoine de l'édition }\end{array} \\ \begin{array}{l}\text { 395 Wellington Street } \\ \text { Ottawa ON K1A 0N4 } \\ \text { Canada }\end{array} & \begin{array}{l}\text { 395, rue Wellington } \\ \text { Ottawa ON K1A 0N4 } \\ \text { Canada }\end{array}\end{array}$

Your file Votre référence ISBN: 978-0-494-47498-3

Our file Notre référence

ISBN: 978-0-494-47498-3

NOTICE:

The author has granted a nonexclusive license allowing Library and Archives Canada to reproduce, publish, archive, preserve, conserve, communicate to the public by telecommunication or on the Internet, loan, distribute and sell theses worldwide, for commercial or noncommercial purposes, in microform, paper, electronic and/or any other formats.

The author retains copyright ownership and moral rights in this thesis. Neither the thesis nor substantial extracts from it may be printed or otherwise reproduced without the author's permission.
AVIS:

L'auteur a accordé une licence non exclusive permettant à la Bibliothèque et Archives Canada de reproduire, publier, archiver, sauvegarder, conserver, transmettre au public par télécommunication ou par l'Internet, prêter, distribuer et vendre des thèses partout dans le monde, à des fins commerciales ou autres, sur support microforme, papier, électronique et/ou autres formats.

L'auteur conserve la propriété du droit d'auteur et des droits moraux qui protège cette thèse. $\mathrm{Ni}$ la thèse ni des extraits substantiels de celle-ci ne doivent être imprimés ou autrement reproduits sans son autorisation.
In compliance with the Canadian Privacy Act some supporting forms may have been removed from this thesis.

While these forms may be included in the document page count, their removal does not represent any loss of content from the thesis.
Conformément à la loi canadienne sur la protection de la vie privée, quelques formulaires secondaires ont été enlevés de cette thèse.

Bien que ces formulaires aient inclus dans la pagination, il n'y aura aucun contenu manquant.

\section{Canada}




\begin{abstract}
$\underline{\text { Abstract }}$
The production of ethanol from cereal grains for use in transport fuels has received considerable attention as a measure to reduce greenhouse gas (GHG) emissions and to reduce fossil fuel consumption, but a thorough and systematic assessment of this potential remains elusive. Life Cycle Assessment (LCA) provides a framework to account for all stages of fuel production and to estimate net reductions, but biofuel LCA work to date has largely ignored regional variations in ethanol production processes. In this investigation, LCAs were completed for the ethanol-gasoline blend fuel E5 and for pure gasoline in two regions of the Province of Ontario (Canada), southern and eastern Ontario. These regional assessments were also compared to a third more generalized province-wide assessment.
\end{abstract}

Producing grain corn for ethanol in the southern Ontario regional case was estimated to require $80 \%$ less fossil fuel and emit $65 \%$ fewer GHG than the eastern Ontario case, but blending with gasoline derived from oil-sand crude oil brought into the region, causes E5 from the southern region to have approximately $10 \%$ higher estimated overall fossil fuel use and emit 5\% more GHG emissions than E5 from the less agriculturally productive eastern region. The main findings from the second type of comparison (regional vs. provincial) were that provincial LCA assessments are adequate for a preliminary estimate of fossil fuel and GHG reductions; but that the more refined regional LCA assessments better delineate processes to help optimize biofuel GHG and fossil reduction potential. Furthermore, the results from the regional assessments introduce the possibility that, 
within Ontario, some E5 fuels require more fossil fuel and emit more GHG than some gasoline fuels.

Overall this research has extended the understanding of the potential for biofuels generally and for E5 fuels specifically to address societal concerns regarding climate change mitigation and energy alternatives. This thesis suggests that E5 fuels will have at best a modest role in mitigating climate change and substituting for fossil fuel resources. Regional factors (e.g. corn yield) and factors external to the region (e.g. source of crude oil) alter the potential for biofuel to reduce fossil fuel use and GHG emissions, particularly as the proportion of ethanol in the biofuel blend increases. Finally, despite challenges to the application of LCA to biofuels, LCA provides a powerful framework to capture not only the long production chain of the biofuel commodity but also regional dimensions within that production chain. 


\section{Acknowledgments}

This work would not have been possible without the willingness of the individual corn producers and ethanol plant managers who participated and shared information. Thank you. Additionally I thank Greg Stewart from Ontario Ministry of Agriculture, Food and Rural Affairs for essential information and contacts. The GHGenius model provided critical data for the project and I appreciate the good work of Don O'Connor and others in developing the model and answering my questions.

Mike Brklacich, my supervisor, provided - and I hope will continue to provide - valuable advice on my research. Amidst his many other responsibilities at Carleton, he found the time to cheerfully steer this work towards a better place. I also thank John Polak for his advice and reviews. Additional thanks to my "thesis support group" for good times and willing ears.

Finally, my returning to university to complete a Master's degree is a dream that has become possible only by a combination of people. First, thanks to my former bosses Susan Herbert and Scott McDougall - for enabling the first steps. Second, thanks to my parents Harold and Marjorie for easing the financial burden. Lastly, thank you to my beautiful wife, Eleanor, for your support and understanding. 


\section{TABLE OF CONTENTS}

1. Introduction to the research subject .......................................................................................... 1

$1.1 \quad$ Thesis Objectives .................................................................................... 5

2. Fundamentals of ethanol biofuels for transport ........................................................... 7

2.1 Basis for energy security and climate change mitigation benefits......................... 8

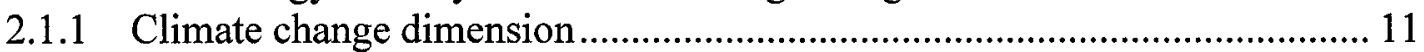

2.2 Producing ethanol blend gasoline ……………….......................................... 12

2.2.1 Step 1: Farming corn................................................................................. 13

2.2.2 Step 2: Fermenting corn to ethanol ............................................................ 14

2.2.3 Step 3: Crude oil recovery / extraction ........................................................ 15

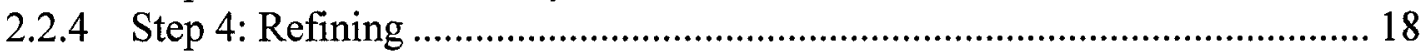

2.2.5 Step 5: Blending................................................................................. 19

2.2.6 Step 6 and 7: Distribution and use ......................................................... 19

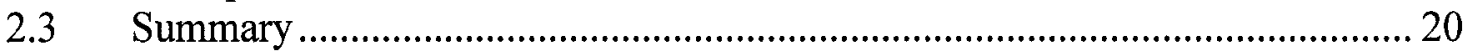

3. Using Life Cycle Assessment to assess fossil fuel requirements and GHG emissions for biofuels............................................................................................................... 21

3.1 Applying LCA to biofuels - the literature ....................................................... 23

3.1.1 Interpretation note on how energy use is reported......................................26

3.2 Applying LCA to Biofuels - the concerns......................................................2 27

3.2.1 Using shared rules................................................................................... 28

3.2.2 Spatial and Temporal Representativeness ...................................................... 31

3.2.3 Accounting for extremely complex and variable ecosystem processes........ 33

3.2.4 Accounting for extremely complex and variable human processes............... 33

4. - Selecting the locations for study ..................................................................................... 36

4.0.1 LCA literature for study location and the GHGenius model .......................... 39

4.1 Developing the S.Ont case study ................................................................... 41

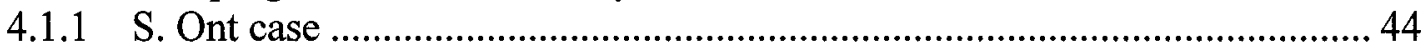

4.2 Developing the E.Ont case study ................................................................. 45

4.2.1 E. Ont Case study .................................................................................... 46

4.3 Developing the generic Ontario base case and gasoline cases .......................... 47

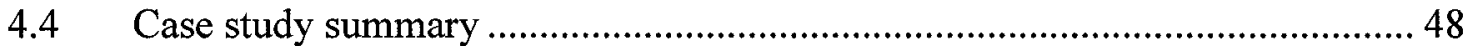

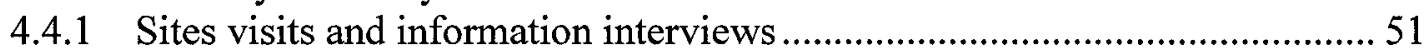

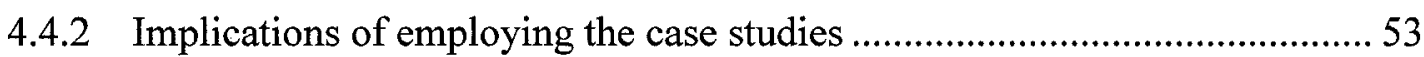

4.4.2 Implications of management styles.............................................................. 55

5. Implementing the research framework ...............................................................5 57

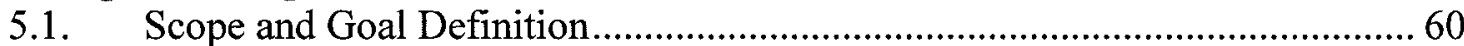

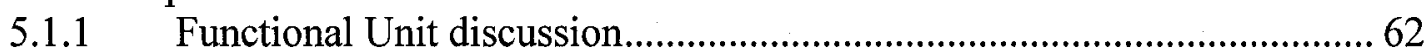

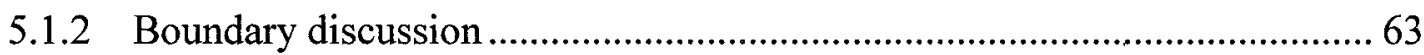

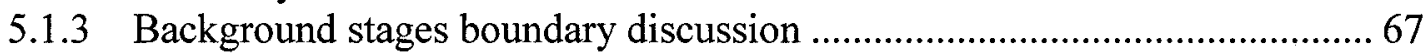

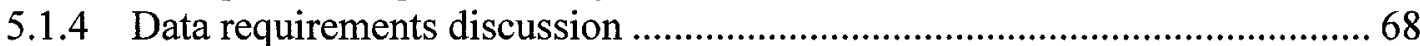

5.2 Inventory Analysis ............................................................................ 71 


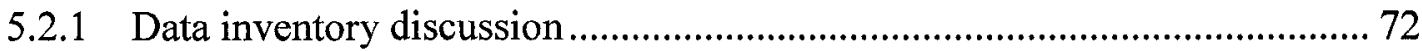

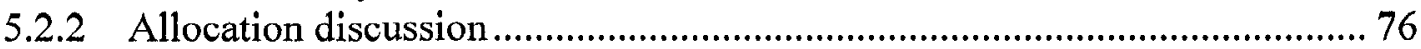

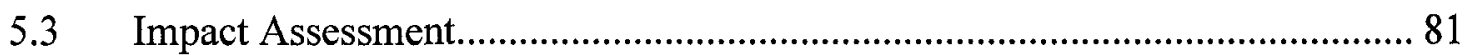

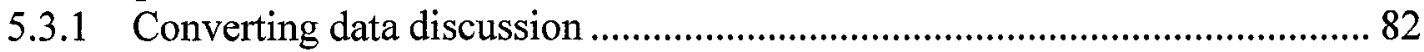

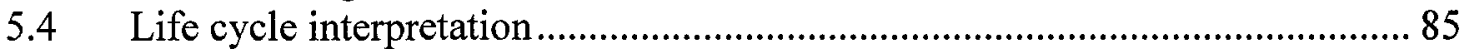

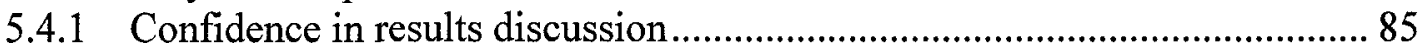

5.5 Summary: Application of ISO 14044 to this LCA ................................... 90

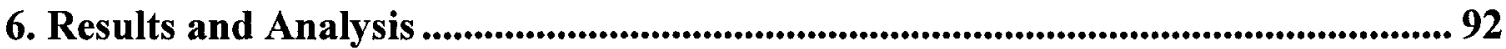

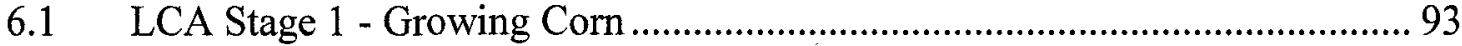

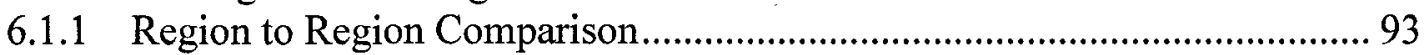

6.1.2 Provincial to Regional Comparison .......................................................... 98

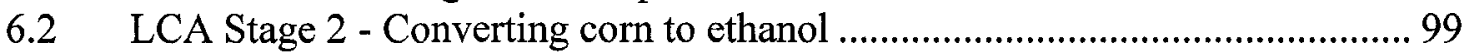

6.2.1 Region to Region Comparison........................................................... 99

6.2.2 Provincial to Regional Comparison ......................................................... 101

6.3 LCA Stages $3 \& 4$ - Gasoline production stages ......................................... 102

6.3.1 Region to Region Comparison .............................................................. 102

6.3.2 Provincial to Regional Comparison ..................................................... 103

6.4 LCA Stages 5,6 \& 7 - Blending, Sale and Use stages .................................. 104

6.4.1 Region to Region Comparison................................................................ 104

6.4.2 Provincial to Regional Comparison ........................................................ 105

6.5 Complete life cycle results..................................................................... 105

6.5.1 Region to Region Comparison.......................................................... 105

6.5.2 Provincial to Regional Comparison ....................................................... 109

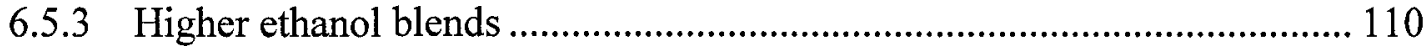

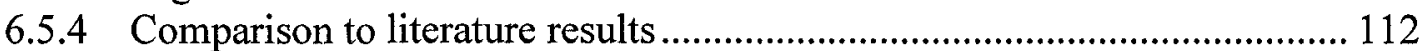

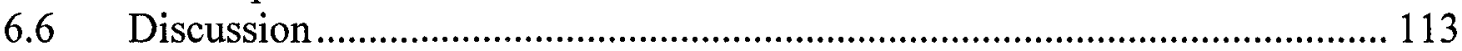

6.6.1 Extent of fossil fuel and GHG emission reductions in regions of Ontario. 113

6.6.2 On the need to consider regional differences in biofuel LCA .................... 117

6.6.3 A preliminary regional difference discussion in biofuel LCA................... 121

6.6.4 Scale matters - bringing geography into the discussion .......................... 123

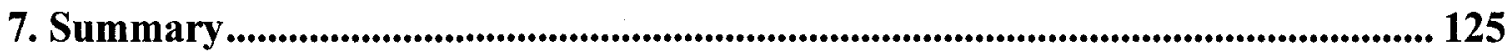

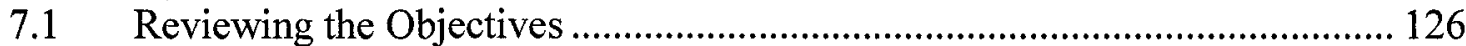

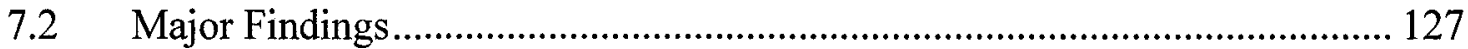

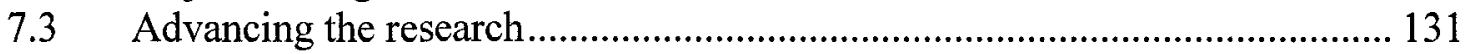

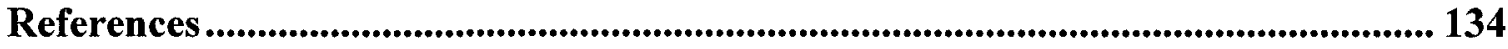

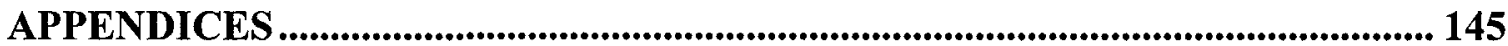




\section{List of Tables}

Table 1.1 Main objectives of bioenergy development in G8 +5 countries (p.1)

Table 1.2 Categories of bioenergy (p.2)

Table 2.1 Conventional and oil-sand oil compared (p.3)

Table 2.2 Products derived from oil (p.10)

Table 2.3 Summary of E5 life cycle stages (p.20)

Table 3.1 Applications of Life Cycle Assessment (p.22)

Table 3.2 Energy and life-cycle assessments of corn starch ethanol in North America 1979-2008 (p.25)

Table 3.3 Addressing challenges of biofuel LCA research (p.28)

Table 4.1 Location involved in production of E5 fuel in S.Ont and E.Ont (p.36)

Table 4.2 Grain corn production in Ontario $2005-2008$ (p.38)

Table 4.3 Agricultural characteristics of Lambton County (p. 42)

Table 4.4 Agricultural characteristics of E.Ont corn supplying regions (p. 46)

Table 4.5 Summary of how regional and case study features match up (p.49)

Table 4.6 Informants helping scope the study (p.53)

Table 5.1 Requirements for "goal and scope definition" phase and correspondence of this LCA (p.60)

Table 5.2 Boundary for background life cycle stages of E5 production (p.68)

Table 5.3 Requirements for "inventory analysis" phase and correspondence of LCA (p.71)

Table 5.4 Origin of inventory data for products considered in this LCA (p.74)

Table 5.5 Requirements for "inventory analysis" phase and correspondence of LCA (p.81)

Table 5.6 Selected examples of conversion factors used in this study (p.83)

Table 5.7 Requirements for "impact assessment" phase and correspondence of LCA (p.85)

Table 5.8 Completeness check - implications of incomplete or inconsistent data (p.86)

Table 5.9 Summary of sensitivity checks (p.88)

Table 6.1 Organization of results (p.93)

Table 6.2 Comparison of top ranked farming activities in S.Ont and E.Ont (p.94)

Table 6.3 Totals from E5 life cycle stage 2 - converting corn to ethanol (p.100)

Table 6.4 Fossil fuel use and greenhouse gas emissions per car trip from gasoline production stages of $\mathrm{E} 5$ production (p.103)

Table 6.5 GHG impacts for blending E5 fuel (p.104)

Table 6.6 Benefits when using E5 versus gasoline based on life cycle comparison on three Ontario cases (p.106)

Table 6.7 Comparing complete life-cycle GHG emissions and fossil fuel consumption for S.Ont and E.Ont regional case studies (p.107)

Table 6.8 Errors introduced by provincial assessment in E5 biofuel LCA (p.109)

Table 6.9 Fossil energy and greenhouse gas reductions versus gasoline with different ethanol blends per $45 \mathrm{~km}$ car trip (p. 111)

Table 6.10 Energy return on investment $\left({ }_{\mathrm{r}} \mathrm{E}\right)$ : Comparison of literature values (p.113) 


\section{List of Figures}

Figure 2.1 Steps in making ethanol blend gasoline (p. 12)

Figure 2.2 Dry mill ethanol production steps (p.15)

Figure 4.1 Map of S.Ont and E.Ont regions and main case study sites (p.43)

Figure 5.1 Research activities and presentation in thesis (p.59)

Figure 5.2 Phases of an LCA (p. 60)

Figure 6.1 GHG emissions from major activities in E-5 life cycle stage 1 (farming corn) for S.Ont and E.Ont case studies (p.95)

Figure 6.2 GHG emissions from major activities in E5 life cycle stage 1 (corn farming) for S.Ont, E.Ont and yield "normalized S.Ont" (p.97)

Figure 6.3 $\mathrm{CO}_{2}$ eq. emissions for ethanol production by input (p.99)

Figure 6.4 Fossil fuel use: Gen.Ont E5 case (p.106) 


\section{List of Appendices}

Appendix A Discussion of terms used in thesis

Appendix B Flow diagrams and discussion

Appendix C Consent Form

Appendix D Corn farming inventory data (Gen.Ont, S.Ont, E.Ont)

Appendix E Ethanol plant inventory data

Appendix F Gasoline stage inventory data

Appendix $\mathrm{G}$ Blending and storage stage inventory data

Appendix $\mathrm{H}$ Conversion factors

Appendix I Full LCA results and \% calculations 


\section{Introduction to the research subject}

Fuels can be defined as any material from which technologically useful energy is derived (Boustead and Hancock, 1979), and continued access to energy has been described by Odell (2004) as essential to the ability of any society to survive. Currently, $88 \%$ of the world's energy needs are derived from fossil fuels (IEA, 2007) but a shift to greater use of biomass fuels is encouraged by many governments for multiple reasons (table 1.1). Two reasons are foremost: mitigating climate change with less greenhouse gas (GHG) intensive biofuels; and secondly, improving energy security by substituting renewable biobased fuels for increasingly scarce and insecure fossil fuels. General environmental improvement and rural development objectives are almost as common.

Table - 1.1 Main objectives of Bioenergy Development in G8 + 5 countries from FA0, 2007, pg.22 table 2.1

\begin{tabular}{|c|c|c|c|c|c|c|c|}
\hline Country & 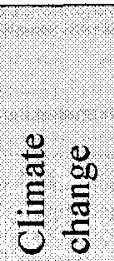 & 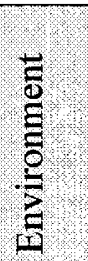 & 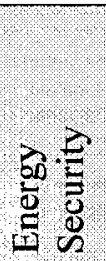 & 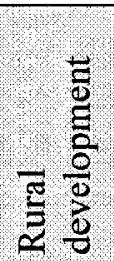 & 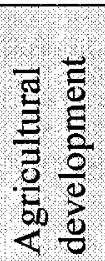 & 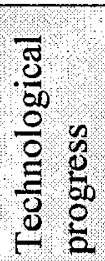 & 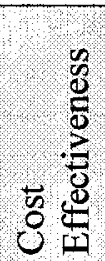 \\
\hline Brazil & $\mathrm{X}$ & $\mathrm{X}$ & $\mathrm{X}$ & $\mathrm{X}$ & $\mathrm{X}$ & $\mathrm{X}$ & \\
\hline China & $X$ & $\mathrm{X}$ & $\mathrm{X}$ & $\mathrm{X}$ & $\mathrm{X}$ & & \\
\hline India & & & $\mathrm{X}$ & $\mathrm{X}$ & & $\mathrm{X}$ & $\mathrm{X}$ \\
\hline Mexico & $\mathrm{X}$ & $\mathrm{X}$ & $X$ & $\mathrm{X}$ & & $\mathrm{X}$ & \\
\hline South Africa & $\mathrm{X}$ & & $\mathrm{X}$ & $\mathrm{X}$ & & & \\
\hline & & 2 & $x=$ & 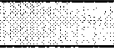 & 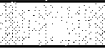 & 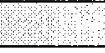 & 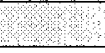 \\
\hline Canada & $\mathrm{X}$ & $\mathrm{X}$ & $\mathrm{X}$ & & & $\mathrm{X}$ & \\
\hline France & $X$ & & $\mathrm{X}$ & $\mathrm{X}$ & $\mathrm{X}$ & & \\
\hline Germany & $X$ & $\mathrm{X}$ & & $\mathrm{X}$ & $\mathrm{X}$ & $\mathrm{X}$ & $\mathrm{X}$ \\
\hline Italy & $X$ & & $\mathrm{X}$ & & $\mathrm{X}$ & & \\
\hline Japan & $X$ & $\mathrm{X}$ & & & $\mathrm{X}$ & $\mathrm{X}$ & \\
\hline Russia & $\mathrm{X}$ & $\mathrm{X}$ & $\mathrm{X}$ & $\mathrm{X}$ & $\mathrm{X}$ & $\mathrm{X}$ & \\
\hline UK & $X$ & $X$ & $X$ & $\mathrm{X}$ & & & $\mathrm{X}$ \\
\hline US & & $\mathrm{X}$ & $\mathrm{X}$ & $\mathrm{X}$ & $\mathrm{X}$ & $\mathrm{X}$ & \\
\hline
\end{tabular}


Bioenergy falls into several categories, and among these, transportation biofuels are undergoing particularly rapidly growth (table 1.2). Increases in production of these fuels around the world, timed with a rise in energy and cereal prices, have sparked many questions about biofuel's impact on other production systems, social impacts, and net environmental effects, including increased scrutiny of the GHG and fossil fuel reduction potential that has driven bioenergy development to date.

Table 1.2 - Categories of bioenergy

\begin{tabular}{|c|c|}
\hline Bioenergy category & Key attributes \\
\hline Traditional & $\begin{array}{l}\text { solid biomass e.g., wood and charcoal } \\
-\quad \text { used for thousands of years for heating, light and cooking } \\
\text { make up approximately } 7 \% \text { of the world's primary energy } \\
\text { supply (IEA, 2004) }\end{array}$ \\
\hline $\begin{array}{l}\text { Biomass for industrial } \\
\text { heat and power }\end{array}$ & $\begin{array}{l}\text { used by natural resource based industries for heating } \\
\text { processes or to turn turbines to make electricity } \\
\text { provides for up to } 3 \% \text { of electricity production in OECD } \\
\text { regions (IEA, 2004). } \\
\text { use of wood waste and various waste "liquors" from pulp } \\
\text { and paper mills is largest form of bioenergy in Canada } \\
\text { (SDTC, 2006). }\end{array}$ \\
\hline $\begin{array}{l}\text { Biogas for heat and } \\
\text { power }\end{array}$ & $\begin{array}{l}\text { methane gas derived from anaerobic breakdown of } \\
\text { biomass in landfills or sewage or manure } \\
\text { drives turbines for electricity or provide industrial heat }\end{array}$ \\
\hline $\begin{array}{l}\text { Liquid biofuels for } \\
\text { transport }\end{array}$ & $\begin{array}{l}\text { Gasoline substitutes produced from starch (the grain of } \\
\text { wheat or corn), sugar (stalks of sugarcane, root of } \\
\text { sugarbeet), or less commercially, cellulose (cell walls of } \\
\text { all plants) fermented to ethanol for use in vehicles } \\
\text { - Diesel substitutes are produced from oils of soybean, } \\
\text { palm oil or waste vegetable oils. } \\
\text { during } 2000 \text { to } 2006 \text {, global ethanol production increased } \\
75 \% \text {, with two and three fold increases in Canada and the } \\
\text { United States (FAO, 2007). } \\
1 \% \text { of the world's current liquid fuel supply, but account } \\
\text { for } 17 \% \text { of new fuel volume in } 2006 \text { (WRI, 2006). }\end{array}$ \\
\hline
\end{tabular}


The trend towards increased production of biofuels appears set to continue into the future but takes place in a context of an urgent need to understand and ultimately identify the most advantageous situation (if any) for commercial biofuel production. A flurry of attention to the biofuel option at high level international meetings has resulted in commitments: to in-depth studies (FAO Conference, April 2008); to develop benchmarks and indicators for sustainable biofuel production and use (G8 Statement, July 2008); and to develop indicators with special attention to minimum $\mathrm{CO}_{2}$ savings and land use (EU, June 2008). In Canada, the House of Commons debated the merits of biofuel (Hansard, May 2008) and ultimately passed a bill (c-33, receiving Royal Assent June 2008) permitting the government to create a guaranteed market for biofuel by legislating a $5 \%$ minimum ethanol content in gasoline by 2010 .

Net fossil fuel and greenhouse gas benefits can only be revealed by considering the entire extraction, production and use stages ("life-cycle") of biofuel production. The Life Cycle Assessment (LCA) tool provides the required framework and is widely used to inform decisions about biofuels. For example, the New Zealand government mandates biofuels that meet sustainability principles including "emit significantly less greenhouse gases over their life cycles than fossil fuels" (New Zealand Govt., 2008). The Dutch government proposes that life cycle greenhouse gas emission reductions of imported ethanol must be greater than 50\% in 2010 (Smeets et al, 2007). 
To date, national or state and provincial LCAs of the greenhouse gas and fossil energy reductions potential of biofuel are widely used. These broad scale assessments have succeeded in providing insight into the margin of potential reductions, and have identified the kinds of activities which contribute most emissions within the biofuel production chain. However, as with any broad scale assessment, regional variations are masked. This is particularly important for corn-based ethanol as substantial differences in corn yield and production techniques are common over short differences.

As the ethanol industry expands throughout the world and within Canada, it is relevant to consider if results from the life cycle assessment method used to measure the industry's contribution to mitigation of climate change and energy remains accurate when production takes place in diverse locations within a larger region. It is important that LCA considers variability in agricultural productivity and in fuel infrastructure as these two factors (and others) change through space and will alter the life cycle fossil fuel energy requirements and greenhouse gas emissions of $\mathrm{E} 5$ production.

The geographic focus of the study is Ontario, Canada. Canada is a developed, industrial nation pushing towards greater commercial bioenergy production and is ranked $5^{\text {th }}$ in world production of ethanol (WRI, 2006). Ontario was one of the first jurisdictions in Canada to mandate a minimum fuel (bio)ethanol content in gasoline (5\% ethanol known as E5 fuel) and accounts for more than half of Canada's production of ethanol (CRFA, 2008). The industry is growing and ethanol production facilities are expanding beyond 
the southern region of the province (that produces large amounts of corn and contains petroleum refineries), to other regions, particularly the eastern part of Ontario.

This study focuses on the short to medium term (i.e. next three to five years) during which time low blends of ethanol derived from corn will remain the predominant form of transport biofuel in the province and wider region. Eventually higher blends (e.g., E85) of ethanol could be more widely used but the infrastructure in terms of vehicles able to use the fuel, stations to the sell the product and lack of supply make this a less certain longer term scenario. Likewise, although ethanol can be made from grasses or straw (or any plant matter) this advance remains a pilot phase technology not yet relevant to the on the ground situation for transport biofuels.

\subsection{Thesis Objectives}

The two key research question that are of equal importance for this thesis are "How important is it to include regional variability in LCAs of biofuel" and "To what extent might the use of E5 in light duty gasoline vehicles result in fossil fuel savings and decreased greenhouse gas emissions? " In order to address these two questions there are two corresponding objectives.

Objective 1: To compare fossil fuel requirements and greenhouse gas emissions for E5 and gasoline fuel production in two regions in Ontario using life-cycle assessment. 
Objective 2: To assess the need for life cycle assessment to incorporate regional differences associated with $\mathrm{E} 5$ production.

Overall, this study provides evidence of the extent to which the examined environmental impacts vary through different locations. Results from this project serve as preliminary information on a path towards optimizing biofuel production, and will provide insight on the appropriateness of more refined- regional biofuel assessments.

Chapter two establishes the information needed to address the research question by documenting the many diverse activities required to make ethanol blend gasoline and highlighting the need for an assessment method that can account for the long production chain. LCA is effective at incorporating hidden environmental impacts, but there are a number of challenges faced when conducting biofuel LCA research. The biofuel LCA literature and these challenges are discussed in chapter three and returned to throughout the work. Chapter four identifies the focus of the research and constructs case studies for E5 fuel and for gasoline for two regional cases and a provincial base for a total of six products that will be subject to the LCA. Chapter five documents all methodological choices and assesses conformance with the standard LCA guidance. The lessons learned from applying the standardized guidance are discussed further at the end of chapter six. This chapter comprises the results from the LCA and reports estimates fossil fuel use and greenhouse gas emissions for the case studies. Differences between regions, and between provincial and regional assessments, are analyzed. Chapter seven summarizes the work and provides final conclusions and suggestions for future research. 


\section{Fundamentals of ethanol biofuels for transport}

The use of ethanol alcohol as an automobile fuel dates back to the first automobiles. Multiple sources relate the story that the early Model T automobile was designed to use ethanol and gasoline (California Energy Commission, 1999, WRI, 2007, Renewable Fuels Association, 2008). More recently, ethanol has been promoted as a safer "antiknock" additive to improve the octane rating of gasoline in North America. (California Energy Commission, 1999).

Ethanol is a liquid hydrocarbon with the chemical formula $\mathrm{C}_{2} \mathrm{H}_{5} \mathrm{OH}$ and differs from gasoline only by a smaller molecule size and the presence of an alcohol (-OH) group. (gasoline is a mix of liquid hydrocarbon ranging from shorter chain hydrocarbons $\mathrm{C}_{5} \mathrm{H}_{12}$ to longer molecules $\mathrm{C}_{12} \mathrm{H}_{26}$-). Throughout North America and Europe ethanol is provided to vehicle users as a blend with gasoline at blending levels of between 5\% to $10 \%$. In Brazil, blends range from $25 \%$ ethanol to pure $100 \%$ ethanol, and $85 \%$ ethanol blends are increasingly sold in the United States and to a smaller extent in Canada. Blending of ethanol and gasoline occurs at storage depots and the mixture is trucked to gas stations for use. Overall the existing infrastructure for use and distribution of gasoline is virtually identical to that required for ethanol, with the following comments:

- In the case of blends with greater than $10 \%$ portions of ethanol, modifications to vehicle engines are required to deal with different oxygen content, vapour pressures and corrosivity (Royal Society, 2008). The major change is a fuel sensor to adjust fuel-air ratio depending on the type of blend. Flex-fuel vehicles that are able to run 
on pure gasoline and pure ethanol or any mixture in between make up two-thirds of new vehicle sales in Brazil but are currently a small part of the global vehicle fleet (Szklo et al 2008).

- Wholesale distribution is via tanker truck as gasoline pipelines require retrofits to deal with the tendency of ethanol to mix with water (Smith, 2008).

Ethanol can be commercially derived from grains or plant parts that are high in sugar or starch. In North America, corn and wheat are used. In Europe, sugarbeet, wheat and barley are more common. Sugarcane is used in tropical regions. Rapidly growing nonfood crops such as switchgrass, willow and poplar are technically possible sources but are currently absent from the commercial ethanol supply. Ethanol derived from corn supplies 99.5\% of ethanol facilitis in Ontario (CFRA, 2008) and is the focus of this study.

\subsection{Basis for energy security and climate change mitigation benefits}

The two key reasons introduced earlier for support of biofuel are to improve energy security and to mitigate climate change. This reasoning behind these benefits are worth exploring.

First the desire for energy security. Biofuels offer a renewable supply of fuel that can be used in perpetuity as long as the basis to renew the biomass resource is maintained. This has the potential advantage of providing a stable and secure substitute for oil. Indeed, the use of plant derived ethanol to power cars has been likened to "driving on sunlight" (Marris, 2006) since sunlight is the energy source for plant growth through 
photosynthesis creating the biomass that is ultimately converted to liquid fuel to power automobile engines.

The need to secure oil or an alternative to oil is overwhelming. Oil is embedded in practically all daily activities and infrastructure, and low-cost sources of oil are becoming scarce. Oil production has peaked in the United States and 60 other countries (Randall, 2008). Prices for oil have fluctuated dramatically over the past 5 years from $25 \$ /$ barrel to over a $145 \$$. In areas with large conventional reservoirs (e.g., Iraq, Nigeria) accessibility to the oil resource is contested, and in some instances accessibility to the resource is linked to some of humankind's most egregious violence.

Table 2.1 - Conventional and Oil-sand oil compared

\begin{tabular}{|l|l|l|l|}
\hline & $\begin{array}{l}\text { \$ Cost (lifting/ } \\
\text { operating cost) }\end{array}$ & $\begin{array}{l}\text { Energy efficiency (ratio } \\
\text { of energy out vs energy } \\
\text { in to produce gasoline) } \\
\text { (GHGenius 2007) }\end{array}$ & $\begin{array}{l}\text { GHG emissions } \\
\left(\mathrm{g} \mathrm{CO}_{2} \text { eq } / \mathrm{km}\right. \\
\text { travelled in } \\
\text { vehicle) }\end{array}$ \\
\hline Conventional oil & $\begin{array}{l}8.30 \$ \text { per barrel } \\
\text { (EIA,2008) }\end{array}$ & 3.95 & 55.3 \\
\hline Bitumen & $\begin{array}{l}\text { 6-14 \$ per barrel } \\
\text { (NEB, 2006) }\end{array}$ & 1.71 & 102.5 \\
\hline
\end{tabular}

1. Derived from b13 and b14 of "life-cycle results" sheet in GHGenius model

Even in oil-rich Canada, reserves of conventional and easily extractable oil fields available with minimal extraction efforts (e.g., drill and release of reservoirs of oil) are in decline. Heavier and harder to extract grades of oil mixed with sand (these reserves are known as oil sands or tar sands) now make up more than $70 \%$ of Canada's known oil reserves (CAPP, 2006). Extraction and refining of this dense and viscous form of 
petroleum called bitumen is more costly, more energy intensive and more polluting than conventional oil (table 2.1).

Thus, biofuel holds promise to contribute to energy security through different conceptions of security. Taken from the national security standpoint, biofuel offers a more controllable local energy source, allowing countries with considerable amounts of arable land and water to minimize reliance on foreign sources of oil. Taken from an ecological security standpoint, biofuel, although not without environmental consequences, holds some promise as a replacement for increasingly more polluting sources of crude oil.

Oil produces a remarkably diverse number of products used by society (table 2.2). For this reason and variety of others (competing demands for grain, finite crop space, other potentially more socially beneficial conservation measures) the promise of grain-based ethanol to substitute for gasoline use can not be claimed as a promise to replace all oil use. Yet, gasoline is where most oil ends up and efforts to replace it with biofuel has the potential to free up oil for other uses where alternatives are harder to find. Indeed it could be considered foolish to burn oil when it could used to make other more useful products

Table 2.2 - Products derived from oil (EIA, 2008)

$\begin{array}{lc}\text { Product } & \text { Percent of oil use } \\ \text { Gasoline } & 47 \\ \text { Heating oil and diesel } & 23 \\ \text { Chemicals, plastics \& rubber } & 18 \\ \text { Jet fuel } & 10 \\ \text { Propane } & 4 \\ \text { Asphalt } & 3\end{array}$




\subsubsection{Climate change dimension}

Promotion of biofuels to reduce greenhouse gases and mitigate climate change has been ongoing for more than a decade (e.g., IPCC 1995), and greenhouse gas savings are a major rationale for Canadian government support of the ethanol industry: "use of renewable fuels can significantly reduce emissions of greenhouse gases"(Canada Gazette, 2006 , vol 40 , no 52). Ontario policy makers claim that 800,000 tonnes of greenhouse gas emissions are avoided through use of 5\% ethanol in Ontario gasoline fuels (Government Ontario, 2008b)

The basis for support relies on the fact that the dominant greenhouse gas - carbon dioxide $\left(\mathrm{CO}_{2}\right)$ - is a food source for plants during photosynthesis. In this process $\mathrm{CO}_{2}$ is metabolised into carbon containing biomass and into oxygen, and when biofuel material is burned $\mathrm{CO}_{2}$ and other gases are released. Those emissions are in turn available for subsequent biomass growth. Combustion of biofuel is considered greenhouse gas neutral as it produces $\mathrm{CO}_{2}$ already in atmospheric cycle, thus saving $\mathrm{CO}_{2}$ from release from the underground immobile pool when fossil fuels are combusted.

Since fossil fuel emissions are currently the primary source of anthropogenic greenhouse gases (IPCC, 2007a), the replacement of some fossil fuel use with biofuel is a potentially significant achievement. The latest global assessment of climate change leaves little room for doubt of the current and future importance of mitigating and adapting to climate change. The Intergovernmental Panel on Climate Change tells policy makers that "warming of the climate system is unequivocal" (IPCC, 2007a, p 2) but that "a portfolio 
of adaptation and mitigation measures can diminish the risks associated with climate change" (IPCC, 2007b., p. 20).

\subsection{Producing ethanol blend gasoline}

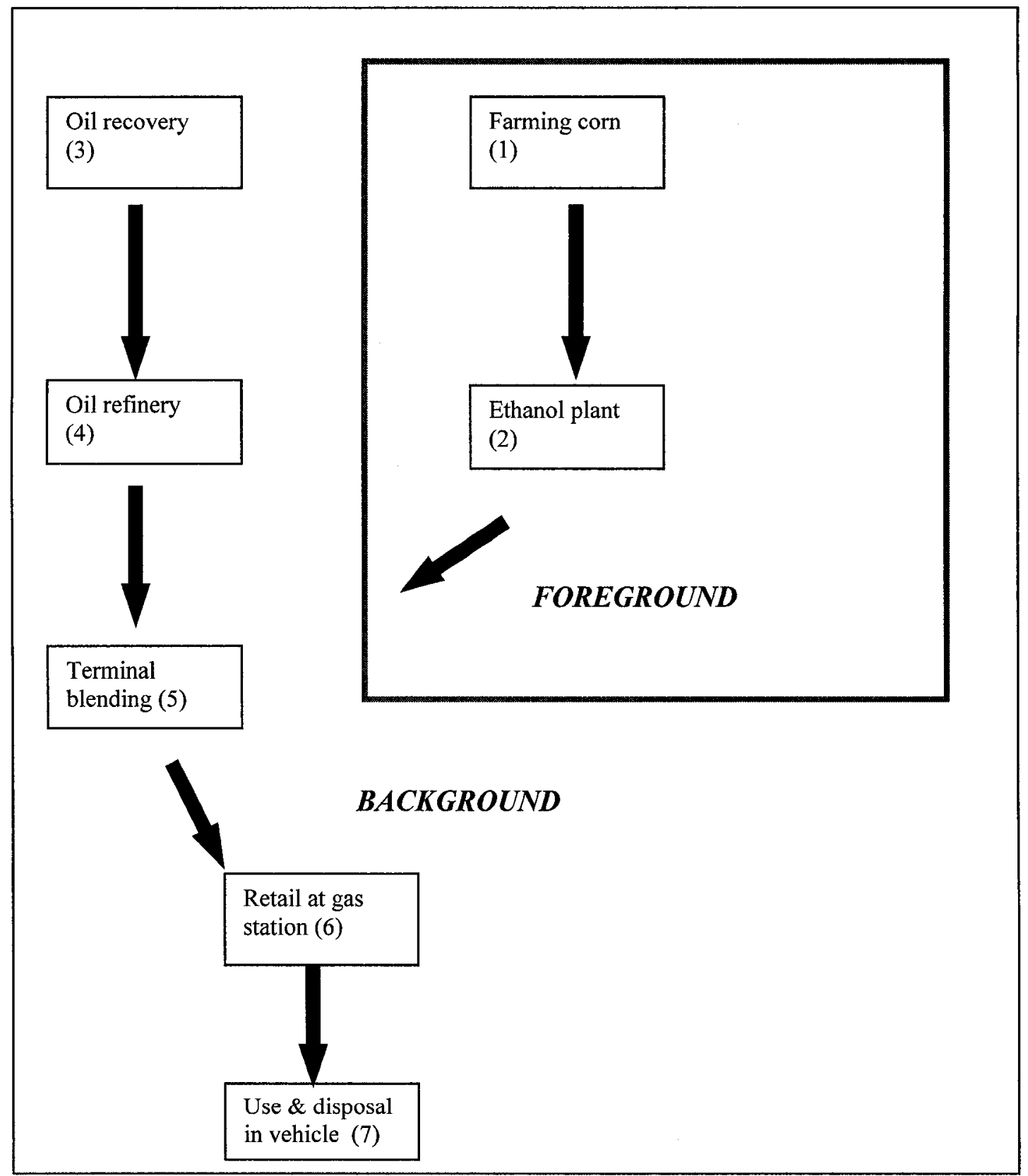

Figure 2.1 - Steps in making ethanol blend gasoline

Note: "Foreground" and "background" refer to differences in data collection strategy for the stages and is described in chapter five. 
Assessing ethanol blend gasoline requires an understanding of how the product is made. The production chain can be broken into seven steps (fig 2.1). 1) farming corn, 2) converting corn to ethanol, 3) extracting oil from underground, 4) refining oil to gasoline, 5) blending gasoline with ethanol, 6) distribution and sale and 7) use in vehicle. Each stage is composed of multiple activities that use fossil fuels and emit greenhouse gases. Ultimately, these contributions must all be factored into assessments of the ethanol blend product. The core activities of each stage are described in the following sections.

\subsubsection{Step 1: Farming corn}

The "extraction" of the corn feedstock for ethanol is achieved through conventional farming methods and does not differ from grain corn for livestock feed. Steps in a typical corn crop production process are:

1) Primary tillage - ploughing of the field in the fall after harvest, typically with tractor and moldboard plough

2) Secondary tillage - ploughing of the field to prepare for planting in the spring, typically with tractor and chisel plough

3) Seeding and fertilizing - seeding of corn with tractor and planter. Seeding and fertilizing is typically simultaneous with application of a starter fertilizer mixture of nitrogen, phosphorous and potassium and a pure nitrogen application

4) Herbicide - spraying of herbicide to control weeds while corn is young and low to ground with a tractor-sprayer

5) Harvest - harvest of the corn crop in the fall with a combine and grain buggies to move corn to storage or drying 
6) Drying - corn grain is dried with natural gas or propane fired hot air dryers and stored

7) Transport - transport to point of sale

These activities will differ depending on the farm location, land quality, and agronomic choices made at the farm-level. For example, growing corn with no tillage will eliminate the tillage steps but usually involves a separate herbicide "spring burn down" application to remove weeds. Manure may be applied in the spring or fall and reduce other fertiliser needs. Despite these many variations, a key point is that each of these activities directly requires energy and directly emits greenhouse gases. Furthermore the input of embodied energy and greenhouse gas emissions from seeds, fertilisers and pesticides must also be considered as part of any studies of biofuel production and use.

\subsubsection{Step 2: Fermenting corn to ethanol}

Corn grain is turned into alcohol at an ethanol plant. The most common type of plant is a "dry mill" plant so called because the first activity is crushing the corn kernel in a mill without addition of liquid (figure 2.2).

The second step after milling and crushing the corn grain is to mix the flour with hot water and an enzyme (alpha-amylase) to facilitate breakdown to sugars and other smaller carbohydrate molecules. ${ }^{1}$ The resulting slurry is cooled and then fermented with the addition of yeast and nutrients. The resulting liquid "beer" is distilled in a series of towers to recover the ethanol which is subsequently sieved, mixed with $1 \%$ gasoline and

\footnotetext{
${ }^{1}$ The similarity to the refining steps of crude oil to gasoline are remarkable. In both instances a feedstock molecule is broken down to smaller pieces. In an ethanol plant by the action of enzymes and in a refinery by high temperatures to "crack" the oil molecule. Subsequent distillation steps are also similar.
} 
becomes ready for transport. Fermentation of carbohydrate produces alcohol and carbon dioxide. The $\mathrm{CO}_{2}$ may be captured and compressed for use or scrubbed and vented.

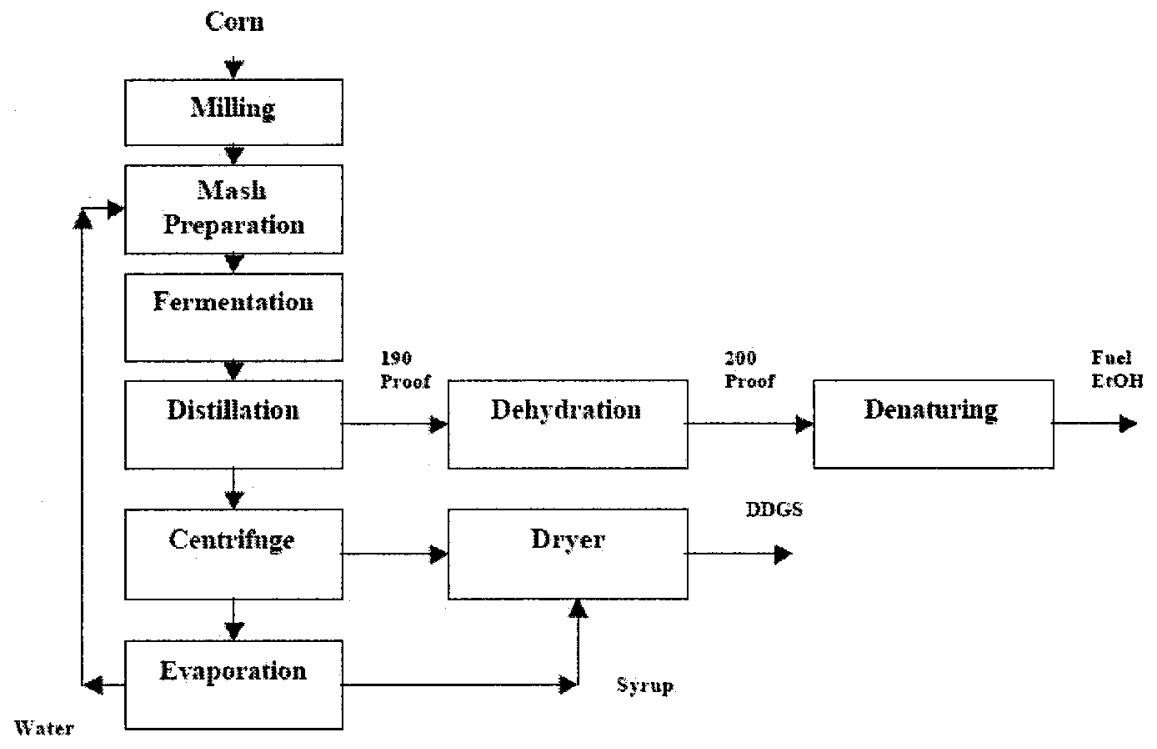

Figure2.2: Dry mill ethanol production steps from Graboski, 2002 p.18

The non-alcohol portion of the distilled beer contains fibre, fat, protein and yeast and is collected from the distillation tower and centrifuged to remove solids. These solids ("whole stillage") are dried in kiln dryers fired by natural gas. The liquid portion of the distilled beer ("thin stillage") is evaporated and the resulting syrup added to the solids in the dryers. The resulting product is called distillers dried grain with soluables (DDGS) and is separate outcome of the process that is sold as animal feed.

\subsubsection{Step 3: Crude oil recovery / extraction}

The extraction of crude oil can be done in three different ways: conventional drilling of oil wells to release and pump oil from underground reservoirs; drilling to underground reservoirs from off-shore locations; and open pit mining or specialized drilling techniques to extract bitumen (highly viscous oil) and subsequent upgrading. 
Conventional drilling involves drilling a series of wells to reservoirs and the unaided flow of oil upwards to the surface. This is referred to as primary recovery and later can be assisted with pumping. Secondary recovery involves injection of water or gases (typically natural gas) to maintain reservoir pressure and increase the flow of oil to the surface. Tertiary or enhanced techniques may also be used by injecting heat to reduce oil viscosity, injecting displacing fluids that interact directly with the oil or by adding chemicals to the displacing fluid to change its viscosity. Heat is provided by heating water to produce steam, that is in turn injected into the reservoir. Heat may also be produced by in situ combustion of a portion of the oil.

Once recovered, initial processing to remove water and gas is done at the well-site. The water may require treatment and the gas may be used to generate power or re-injected into the site.

Primary and secondary recovery does not extract all of the oil in the reservoir. For heavy and medium grades, recovery of less than $50 \%$ of oil is typical (Shell, 1983).

Offshore drilling involves the same basic activities of onshore sites - namely drilling and maintaining wells for primary and secondary recovery. Offshore platforms must be put in place before drilling can begin. These structures are varied and can be floating or fixed to the sea surface. They store oil for transport by tanker or directly supply pipelines (Shell, 1983). 
Bitumen mining and in-situ bitumen extraction involve the extraction of nearly solid highly viscous oil (bitumen). For North America, the activities of bitumen mined in the sand substrate of northern Alberta (oil sands) is most relevant. The bitumen is extracted in one of two ways:

- $\quad$ surface mined as a sand-bitumen mixture with large trucks and buckets, and subsequently oil and sand is separated, or

- in situ extraction by injecting steam repeatedly into the deposit to reduce oil viscosity and the released oil flows to drilling wells. A second method of in-situ extractions is "steam assisted gravity drainage" in which two horizontal wells are drilled into the reservoir. The first well carries steam to release the bitumen which drops into the lower by gravity to be pumped to the surface. (Gov. Alberta, undated a)

In the case of surface mining, a series of processing steps must be completed before the product is sent to a refinery. Hot water is applied to separate the bitumen from the sand in settling tanks known as separation vessels. A series of secondary separation techniques involving injection of air and then steam is used to extract the remainder of bitumen (Gov. Alberta, undated b).

Once the bitumen has been recovered it can be sent to refineries equipped to refine it to gasoline, diesel and other products. However, not all refineries can refine bitumen and some is first converted to a conventional crude oil quality product known as synthetic crude oil or "syncrude" that all refineries can accept. The Syncrude process takes place 
at an upgrading facility and involves heating the bitumen to $500^{\circ} \mathrm{C}$ to break the oil into smaller molecules (also called "thermal cracking"). Thermal cracking can also be aided by catalysts via "catalytic conversion". The next stage is distillation in a distillation tower which again uses heat to separate the product. The last stage is to mix hydrogen with the product to stabilize the molecules and give it the same structure as conventional crude oil. (Government Alberta, undated c)

\subsubsection{Step 4: Refining}

The transformation of crude oil into gasoline takes place in a refinery. Each refining step involves the application of energy in the form of heat and chemicals. Energy is used throughout the process and greenhouse gases are emitted. As a general rule, the heavier the crude oil that is going into the refinery, the smaller the gasoline yield and the more equipment and energy required to obtain gasoline. The following description is based on Chevron (2007) and Wikipedia (2008).

The first step is boiling of crude and distillation of the product into different fractions. Gasoline has a relatively low boiling point and is separated from other products including diesel and kerosene. These are called "straight-run" products and can move quickly to the final mixing steps. Secondly, heavier fractions are broken down ("cracked") using $500^{\circ} \mathrm{C}$ heat with or without additional chemical catalysts (c.f. similar stage in upgrading process). Fluid catalytic cracking (FCC) is a technique employed in all refineries that involves preheating the substrate and mixing with catalyst, and subjecting the mixture to changes in pressure. Hydrocracking is another stage using hydrogen as catalyst. Additional steps to combine smaller compounds into gasoline are used and 
"Hydrotreating" is a common step and generic term for treating feedstock with hydrogen to remove impurities. Sulphur is one such impurity and "desulphurization" can be achieved by hydrotreating or other treatments.

\subsubsection{Step..5: Blending}

The blending step is a relatively simple process. Blending occurs by adding gasoline and ethanol together in tanker trucks at the gasoline terminal and the mixture is trucked to various gas stations. The activities of a bulk storage facility or terminal are to receive, store and transfer to trucks the ethanol blend gasoline. Energy is used and greenhouse gases emitted to transport both ethanol and gasoline to the terminal and for storage activities. Pumps are needed to move product around the terminal. Highly viscous materials may require application of heat (and energy) to increase flowability. Large vertical tanks store the product and if storing heavy oils may include heating coils.

\subsubsection{Step 6. and 7:Distribution and use}

The final stages considered in this study are the distribution and retail of the product at the gasoline pump for use in vehicles (the "pump" portion of "plough to pump") where both E-blend fuel and gasoline are delivered to the gas retail location by tanker truck and stored in underground tanks supplying gas pumps. Energy and greenhouse gases are consumed and produced in the transport of product to the gas station, and in the pumping of product into vehicles. Energy is also consumed to maintain the gas station. NRCan (2004) states that sale of ethanol blend gasoline requires modification of the storage tanks and pumps 


\section{$\underline{2.3}$ Summary}

Ethanol blend gasoline is produced through a series of processes with multiple points

where energy derived from fossil fuels is required and GHGs are released (table 2.3).

Both direct sources (e.g., burning natural gas to dry corn mash) and indirect sources (e.g., use of inputs such as electricity or fertilizer whose production requires fossil fuels and GHG emissions) must be considered. It is also important to recognise each stage takes place within unique local and regional settings and likely varies by region.

Table 2.3 - Summary of E5 life cycle stages

\begin{tabular}{|c|c|c|}
\hline Life cycle stage & Key fossil fuel needs & Key climate change emissions \\
\hline Growing corn & $\begin{array}{l}\text { Direct use of fuel for field } \\
\text { activities, many inputs with high } \\
\text { embodied energy (e.g., fertilizer) }\end{array}$ & $\begin{array}{l}\text { Major greenhouse gas } \mathrm{N}_{2} \mathrm{O} \\
\text { released with fertilization, } \mathrm{CO}_{2} \\
\text { released during combustion, } \\
\text { growing corn absorbs } \mathrm{CO}_{2}\end{array}$ \\
\hline Converting to ethanol & $\begin{array}{l}\text { Application of heat, enzymes, } \\
\text { yeast and chemical, heat derived } \\
\text { from a fossil fuel }\end{array}$ & $\begin{array}{l}\mathrm{CO}_{2} \text { released during } \\
\text { combustion, } \mathrm{CO}_{2} \text { from } \\
\text { fermentation captured and sold }\end{array}$ \\
\hline Extracting crude oil & $\begin{array}{l}\text { Energy needs for drilling and oil } \\
\text { recovery depend on location and } \\
\text { type of oil }\end{array}$ & $\begin{array}{l}\text { Flaring of major greenhouse } \\
\text { gas } \mathrm{CH}_{4}, \mathrm{CO}_{2} \text { releases during } \\
\text { combustion }\end{array}$ \\
\hline Refining oil to gasoline & $\begin{array}{l}\text { Application of heat and } \\
\text { chemicals, the heavier the oil the } \\
\text { more energy required }\end{array}$ & $\begin{array}{l}\mathrm{CO}_{2} \text { released during } \\
\text { combustion }\end{array}$ \\
\hline Storage (and blending) & $\begin{array}{l}\text { Minor energy requirements to } \\
\text { power pumps, possibly heat for } \\
\text { viscous fuels }\end{array}$ & $\begin{array}{l}\mathrm{CO}_{2} \text { released during direct } \\
\text { combustion or indirectly } \\
\text { through electricity use }\end{array}$ \\
\hline Retail at pump & $\begin{array}{l}\text { Minor energy requirements to } \\
\text { power pumps and station }\end{array}$ & $\begin{array}{l}\mathrm{CO}_{2} \text { released indirectly } \\
\text { through electricity use }\end{array}$ \\
\hline Use in vehicle & $\begin{array}{l}\text { Energy in fuel transformed into } \\
\text { heat and mechanical energy to } \\
\text { propel vehicle }\end{array}$ & $\begin{array}{l}\mathrm{CO}_{2} \text { released during } \\
\text { combustion }\end{array}$ \\
\hline
\end{tabular}




\section{Using Life Cycle Assessment to assess fossil fuel requirements and GHG emissions for biofuels}

The previous chapter identified a long production chain for blended biofuels with multiple occasions for fossil fuel inputs and multiple points of greenhouse gas emissions. From an environmental analysis perspective, this illustrates the need for analytical tools that can capture all steps in the production chain or product "life cycle" (defined as the "consecutive and interlinked stages of a product system, from raw material acquisition or generation from natural resources to final disposal" (ISO, 2006a, p.2.). Life Cycle Assessment (LCA) is designed to provide a full accounting across all stages of the production chain and thus can provide insight into each stage as well as the full extent of fossil fuel consumed and greenhouse gases emitted throughout biofuel production and use.

The origin of LCA is tied to determining what forms of different products are more environmentally preferable (Hendrickson et al. 2006) but the method is applied to a number of purposes (table 3.1). In 1997, the International Organization for Standardization (ISO) published a formal version of LCA methodology in a series of documents - ISO 14040 "Environmental Management - Life Cycle Assessment principles and framework" is the main document and a second edition was published in late 2006 .

The LCA tool is considered an effective way to evaluate environmental attributes of biofuels (Royal Society 2008, WRI, 2007) and results from LCA evaluations are 
regularly used by policy makers and by the wider community. For example, the Canadian federal government claims life-cycle greenhouse gas reductions (Canada Gazette, 2006) in justifying public funds in support for ethanol. Popular media such as the National Geographic October 2007 cover story on biofuels focussed on life cycle based energy ratios to highlight the most efficient sources for biofuel feedstock (Bourne, 2007). Most biofuel LCA work is restricted to climate change impacts and energy use but LCA for other products typically considers additional environmental impact categories of photochemical oxidant formation (smog), acidification (acid rain), nutrification (algal blooms in lakes), some measure of human toxicity and toxicity to other organisms (e.g., Canals et al 2006).

Table 3.1 - Applications of Life Cycle Assessments

\begin{tabular}{|l|l|}
\hline Application & Key features \\
\hline Production comparison & $\begin{array}{l}\text { Assess environmental impacts of alternate forms of } \\
\text { product (e.g. paper vs. plastic bags, glass vs metal } \\
\text { beverage containers) }\end{array}$ \\
& $\begin{array}{l}\text { Relevant comparisons require care to ensure product } \\
\text { delivers same function as alternative }\end{array}$ \\
\hline Identifying "soft spots" & $\begin{array}{l}\text { Product management tool "you can't manage what you } \\
\text { can't measure" Rebitzer } \text { et al (2003) }\end{array}$ \\
\hline - $\begin{array}{l}\text { Can reduce environmental impacts by changing product } \\
\text { design, substituting different materials or changing } \\
\text { manufacturing process }\end{array}$ \\
\hline Scenario modelling & $\begin{array}{l}\text { Help identify improvement activities with greatest return } \\
\text { - } \begin{array}{l}\text { Predict environmental impact of changes throughout } \\
\text { product system }\end{array}\end{array}$ \\
\hline & $\begin{array}{l}\text { Examples are national energy department models for } \\
\text { transport fuels (GREET 2007, GHGenius, 2007) }\end{array}$ \\
\hline
\end{tabular}




\subsection{Applying LCA to biofuels - the literature}

Larson (2006) documents dozens of life cycle type evaluations performed on transport biofuels such as biodiesel, cellulosic ethanol and corn-ethanol. Within this literature cornethanol studies are particularly common, particularly in the North American context (table 3.2). In reviewing this literature there are several points to consider.

First, corn ethanol continues to be an object of research after more than 30 years. This long-term interest corresponds to policy pushes for ethanol in the late 1970s and again now in 2000-2008. Furthermore there is a lack of consensus in results of these evaluations. A central question on the energy balance of the fuel or "will ethanol yield more energy than it takes to make?" (Chambers et al. 1979, Johnson 1983) continues to be debated (see final column of table). Pimentel (2003), Patzek (2004, 2006), Pimentel and Patzek (2005 p.6) have published a series of energy balance reports that suggest a negative overall energy balance for corn ethanol and conclude that ethanol production "is contributing to oil and natural gas imports". A larger set of research has found the opposite result (e.g,, Farell et al, 2006, Sharpouri 2004, Levelton 2000).

Second, the environmental impacts assessed in biofuel LCA is changing $\left(3^{\text {rd }}\right.$ column in table 3.2). Greenhouse gas savings emissions have been included sporadically since the 1990s and consistently since 2005. Only one study (Kim and Dale, 2005) has analysed environmental impacts beyond energy use and GHG. 
Third, the scope of items included in evaluations is evolving. Early works simply tallied up all of the fossil fuel inputs and multiplied by a conversion factor for amount of carbon dioxide emitted during burning of each fuel to represent overall greenhouse gas emissions in making ethanol. (e.g., Marland and Thurnhollow, 1991). As more analyses have been conducted a fuller consideration of all greenhouses gases, most notably nitrous oxide emissions from agricultural soils, have been included. Now a new emphasis is emerging in the literature to model and account for changes in stored carbon stocks due to predicted land use shifts from non-agricultural land to cropland to meet demands for biofuel (Fargione et al, 2008, Searchinger et al 2008). The challenge of incorporating these changing boundaries into the scope of LCA is returned to later in this chapter.

The last point to consider is that the emergence of LCA occurs midway through this research history. Energy analyses of the 1970s and successor studies rely on a full production chain scope but do not cite or rely on standard LCA guidance, while a separate set of literature relies on LCA as conceived through ISO (2006a,b). This has led to a situation where many terms are used imprecisely which in turn can threaten the quality of assessments of biofuels. Extended definitions of key terms can be found in Appendix A. 
Table 3.2 - Energy and Life-Cycle Assessments of corn starch ethanol in North America 1979 - 2008

\begin{tabular}{|c|c|c|c|}
\hline Name & Product & Aspects evaluated & Energy balance conclusion \\
\hline $\begin{array}{l}\text { Chambers, } \\
\text { Herendeen, Joyce } \\
\text { and Penner, } 1979\end{array}$ & e-10 & Energy, petroleum & $\begin{array}{l}\text { More energy required to } \\
\text { produce ethanol in most cases. } \\
\text { Crude oil savings in all cases. }\end{array}$ \\
\hline $\begin{array}{l}\text { Marland and } \\
\text { Turnhollow, } 1991\end{array}$ & Ethanol & Energy, GHG & $\begin{array}{l}\text { Positive energy balance (energy } \\
\text { in ethanol / fossil energy } \\
\text { inputs). Energy ratio of } 1.29\end{array}$ \\
\hline $\begin{array}{l}\text { Lorenz and Morris, } \\
1995\end{array}$ & Ethanol & Energy & Positive energy balance of 1.38 \\
\hline Wang, 1997 & E10, E85 & Energy, GHG & $\begin{array}{l}\text { Ratio not reported - total energy } \\
\text { per vehicle }\end{array}$ \\
\hline Levelton, 2000 & $\begin{array}{l}\text { E10,E85, } \\
\text { ethanol }\end{array}$ & Energy, GHG & $\begin{array}{l}\text { Positive energy balance. Ratio } \\
\text { of } 1.5\end{array}$ \\
\hline Graboski, 2002 & Ethanol & Energy & $\begin{array}{l}\text { Positive energy balance. Energy } \\
\text { ratio of } 1.21\end{array}$ \\
\hline Pimentel, 2003 & Ethanol & Energy & $\begin{array}{l}\text { Negative energy balance. Ratio } \\
=0.8\end{array}$ \\
\hline $\begin{array}{l}\text { Shapouri and } \\
\text { McAloon, } 2004\end{array}$ & Ethanol & Energy & $\begin{array}{l}\text { Positive energy balance. } \text { Ratio }= \\
1.67\end{array}$ \\
\hline Patzek, 2004 & Ethanol & Energy & $\begin{array}{l}\text { Negative energy balance. Ratio } \\
=0.81^{2}\end{array}$ \\
\hline $\begin{array}{l}\text { Pimental and } \\
\text { Patzek, } 2005\end{array}$ & Ethanol & Energy & $\begin{array}{l}\text { Negative energy balance. Ratio } \\
=0.8\end{array}$ \\
\hline $\begin{array}{l}\text { Dias de Oliveira et } \\
\mathrm{al}, 2005\end{array}$ & Ethanol & Energy, GHG & $\begin{array}{l}\text { Positive energy balance. } \text { Ratio }= \\
1.1\end{array}$ \\
\hline Kim and Dale 2005 & $\begin{array}{l}\text { Biofuel } \\
\text { cropping } \\
\text { system }\end{array}$ & $\begin{array}{l}\text { Energy, GHG, } \\
\text { acidification, } \\
\text { eutrophication }\end{array}$ & $\begin{array}{l}\text { Positive energy balance. } \\
\text { Balance is } 0.77 \mathrm{TJ} / \text { ha avoided } \\
\text { in corn - soyabean rotation both } \\
\text { crops producing fuels }\end{array}$ \\
\hline Farell et al 2006 & Ethanol & Fossil fuels & $\begin{array}{l}\text { Positive energy balance. } \text { Ratio }= \\
1.2\end{array}$ \\
\hline GREET (2007) & $\begin{array}{l}\text { Multiple } \\
\text { fuels }\end{array}$ & $\begin{array}{l}\text { Energy, GHG, CO, } \\
\text { NOx, SO2, PM }\end{array}$ & Various \\
\hline $\begin{array}{l}\text { GHGenius, version } \\
3.112007\end{array}$ & $\begin{array}{l}\text { Multiple } \\
\text { fuels }\end{array}$ & $\begin{array}{l}\text { Energy, GHG, CO, } \\
\text { NOx, SO2, PM }\end{array}$ & $\begin{array}{l}\text { Using default values in model } \\
\text { ratio }=1.57\end{array}$ \\
\hline Fargione et al, 2008 & Ethanol & GHG & $\begin{array}{l}\text { Energy balance not reported but } \\
\text { finds a "carbon debt" that will } \\
\text { take } 93 \text { years to recapture }\end{array}$ \\
\hline
\end{tabular}

1. This table does not include studies of work that reviews use of corn stover to make cellulose based ethanol. It also does not include reviews (e.g. Hammerschlag, 2006, Larson 2005).

2. This value is not directly calculated by author. It is taken from Farell review (2006) 
For von Blottnitz and Curran (2007) the long history of grain ethanol study indicates further LCA work is not necessary and that "depending on crop and geographical location, in many cases it will be possible to obtain a sufficiently reliable estimate from previous work." (p.216 my emphasis) The question of whether or not previous LCA work and large scale LCA assessments can provide a reliable enough estimate of biofuel production across geographic locations is the major research question of this thesis.

\subsubsection{Interpretation note on how energy use is reported}

There are alternate ways of expressing the final energy result of LCA evaluations, but in all, an important theoretical distinction is made between solar energy and the fossil energy of oil and other fossil fuels. Solar energy is considered renewable and free (Chambers, 1979). Fossil energy, despite its original photosynthetic origins, is considered an environmental cost and the less fossil energy used, the better. When completing LCA evaluations this means that the energy content of gasoline counts against the overall energy balance of gasoline but the energy content of the corn grain does not count against the energy balance of ethanol.

Because of this structure, this means that no matter how efficient conventional gasoline is made it will always have a net negative energy balance and a ratio of energy out / energy in that is less than 1. A totally renewable energy based biofuel, on the other hand, if made with wind generated electricity, biomass fueled refinery energy and zero machinery inputs, could have an energy ratio of energy out / energy that approaches infinity. 
Some authors (e.g, Malca and Friere, 2006, Hammerschlag 2006) focus on reporting results in a number that explicitly represents the amount of renewable / free energy that is in the biofuel. Hammerschlag (2006) defines the "energy return on investment" $\left(\mathrm{r}_{\mathrm{E}}\right)$ value represented as the ratio of energy in a litre of ethanol to the non-renewable energy required to make it:

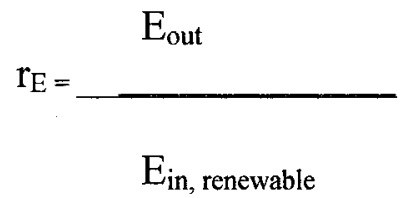

Any values that are below 1 indicate that the total energy in the ethanol is less than that required to make it (a negative energy balance) and values above 1 indicate a positive energy balance and that some renewable energy has been "captured" in the fuel.

It is worth noting that there are differing perspectives on free solar energy. From a thermodynamic perspective no energy is free and all energy is conserved. Energy cannot be created or destroyed, and solar energy should therefore be accounted for in biofuel evaluations (Patzek. 2006). From a social perspective, solar energy may be a common and renewable public good, available to all, but it is only free to users that have the capacity to access and harness its availability.

\subsection{Applying LCA to Biofuels - the concerns}

LCA is a powerful tool providing a useful sense of the impacts of corn ethanol, but the application of LCA to biofuel faces four key challenges (table 3.3). Strategies to address each challenge are proposed here and have been employed to some extent in the LCA conducted in this thesis (hatched boxes). 
Table 3.3 - Addressing challenges of biofuel LCA research (shaded box indicates the approach has been applied in this thesis)

\begin{tabular}{|c|c|c|}
\hline Theme & Aspects & Addressing the challenge \\
\hline Using different rules & $\begin{array}{l}\text { Inconsistent and unclear } \\
\text { LCA design choices } \\
\text { Undermined ability to } \\
\text { compare LCA studies and } \\
\text { build a literature }\end{array}$ & 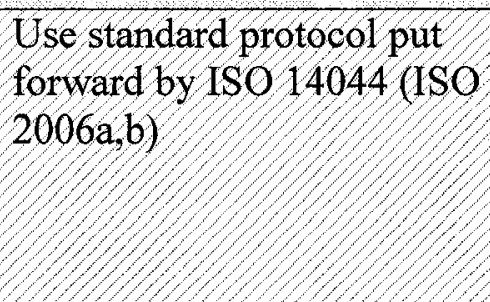 \\
\hline $\begin{array}{l}\text { Spatial and temporal } \\
\text { representation }\end{array}$ & $\begin{array}{l}\text { Local conditions of biofuel } \\
\text { production create plausible } \\
\text { diversity in LCA findings }\end{array}$ & $\begin{array}{l}\text { Determine extent of enror } \\
\text { atroduced by comparing } \\
\text { desutts from different spatia } \\
\text { and temporal scales for } \\
\text { same product system }\end{array}$ \\
\hline $\begin{array}{l}\text { Extremely variable } \\
\text { ecosystem processes }\end{array}$ & $\begin{array}{l}\text { Modelling some natural } \\
\text { processes introduces } \\
\text { uncertainty into results }\end{array}$ & $\begin{array}{l}\text { Jucorporate modelling } \\
\text { adyances } \\
\text { Inchude uncertainty of data } \\
\text { when presenting results }\end{array}$ \\
\hline $\begin{array}{l}\text { Extremely variable human } \\
\text { processes }\end{array}$ & $\begin{array}{l}\text { Ability to integrate } \\
\text { institutional change and } \\
\text { feedback into LCA system } \\
\text { boundary is rudimentary }\end{array}$ & $\begin{array}{l}\text { Combine LCA with other } \\
\text { assessment methods, } \\
\text { employ monitoring and } \\
\text { follow-up }\end{array}$ \\
\hline
\end{tabular}

\subsubsection{Using shared rules}

Conducting an LCA based evaluation involves a series of choices, each with a potentially large influence on the results. Comparing results between studies often requires modifying the original author's analytical choices potentially resulting in stalemate disagreements (e.g., Patzkek's (2007) response to Farell et al 2006) without recourse to a common set of rules for conducting evaluations. This thesis suggests that standard rules are found in the ISO 14040 and 14044 documents (ISO 2006a, 2006b) but these have not 
been widely enough applied. Under-reported design choices that significantly influence the results of assessments makes it difficult for outsiders to interpret results.

Aspects of challenge - to illustrate the utility of using the ISO foundation for analyses examples of key requirements set out by ISO (2006b) that are consistently under-reported in the corn ethanol LCA-type literature are discussed below:

- Establishing a system boundary (e.g. what activities should and should not be included) with explanation of criteria and implications for decisions. This requirement is central to understanding a LCA. A good example of this is the choice to include energy required to make farm machinery by Pimental and Patzek (2005) in the their boundary for ethanol fuel. This increases the overall energy attributed to farming corn by $23 \%{ }^{2}$ compared to other analyses (e.g., Dias de Olivera, 2005), and is a large reason why Pimental and Patzek (2005) report a negative energy balance for corn ethanol. Neither choice is right or wrong but the implications of the decision, particularly if comparing to gasoline energy balances which are examined with a different system boundary, are seldom discussed in the studies reviewed during this work.

- Collecting data at the "unit processes" level. To completely understand and accurately account for energy and greenhouse gas inputs and outputs, data from each individual step (also referred to as "unit processes") in the production process should be listed and data collected (ISO, 2006b). For example, the activity of grinding corn 
to make ethanol requires electricity. The amount of electricity per unit of ethanol produced from this activity could be collected or estimated. However in practice highly aggregated data is used. For example, a common source of ethanol mill electricity data in several studies (e.g., Sharpouri and McAloon, 2004, Dias de Oliveira et al 2005) is a 2001 survey of US facilities in which total electricity use for all activities is reported. This may lead to situations where electricity inputs completely unrelated to ethanol production are included in the LCA.

- Allocating inputs and outputs over co-products. The issue of how to allocate impacts is a recognized issue in the utility of biofuel LCAs (Larson, 2006, Cheminfo 2008). Since production chains rarely produce only one product, a choice must be made by the LCA analyst on how to allocate the inputs to various co-products. A livestock animal feed "dried distillers grain soluables", is produced at ethanol plants and a portion of all of the energy and greenhouse gases can be attributed to this product and some to the final fuel. The choice of allocation approach can determine final results (Malca and Friere, 2006). Standard LCA guidance requires allocation to co-products (ISO 2006b) but it is worth noting that portioning out some impacts to the DDGS co-product is not included by all analysts (e.g., Hoode and Greywood, 2007, Pimentel and Patzek, 2005).

Addressing the challenge- using ISO 14040 (ISO 2006a) and ISO 14044 (ISO 2006b) as the basis for conducting biofuel LCA would help build a more easy to understand biofuel

${ }^{2} 4295 / 18041 \mathrm{MJ} /$ ha from sheet "Pimentel" and sheet "Sharpouri" in EBAMM from Farell et al (2006) 
literature. Many studies do rely on ISO guidance (e.g., Cheminfo, 2008, Malca and Friere 2006, Kim and Dale, 2002).

Given the potential impacts of employing alternative boundaries and units on LCA results there is a need to at least carefully document choices and preferably establish a common set of rules for articulating design choices. The under-reporting of system boundaries, scale of data, and allocation choices complicates the building of a LCA-biofuels literature. These obstacles also hinder efforts, such as the ongoing work by Rowe. et al. (2008) to comprehensively compare all biofuel LCA studies.

The LCA conducted for this thesis follows the ISO 14044 guidance systematically. Section 5 details the process, and lessons learned are found in section 6.6.

\subsection{2 . Spatial and Temporal Representativeness}

Simply performing a state of the art LCA that meets ISO requirements will not provide a definitive picture of the energy and GHG costs of all corn ethanol production. LCA results are based on specific input data from a specific time period and a place; both of which can introduce uncertainty to results. Larson's (2006, p 115) review of biofuel LCAs highlights this point noting that "The wide variation in results from $L C A$ studies... is due in part to the wide range of plausible values for key input parameters, with values often dependent on local conditions." Reap et al (2008) in a review of LCA view local unique conditions as a data problem that reduces accuracy of results. 
Aspects of challenge - this second challenge of spatial and temporal representation is one that affects all modelling exercises but is rarely studied. For example, Kim and Dale (2005) used data from 14 counties in their calculations of biofuel impacts but only to create an average and did not report on variability between counties. The same authors followed the same procedure with data from seven States in Kim and Dale (2004). Another example is the variation in regional crop yields noted by Farrell et al (2006 supplementary data) and Shapouri and McAloon (2004). The authors recognize variation in data but report findings as a national value. Such an approach may be suitable for a national scale assessment but does lead to questions of which particular locations are represented by the LCA result.

Addressing the challenge - there have been some attempts to address the temporal aspect of changes in input data for biofuel LCA. For example the GHGenius model (GHGenius 2007) decreases electricity, diesel, natural gas and other inputs by a percentage from the base-year input values to incorporate expected efficiency changes. Users specify the year of the assessment and the model calculates input data for that particular year. This approach partially addresses the challenge but leaves questions concerning the accuracy of the original value and for how long the efficiency factor remains valid.

The extent to which biofuel LCA results differ by location is central to this study. The research design has been set up to collect and compare input data and results in two locations together with a third base line case using the more common approach of 
regional data. The degree of difference seen in the three LCAs will help indicate the significance of the spatial challenge to biofuel LCAs.

\subsubsection{Accounting for extremely complex and variable ecosystem processes}

Even with well known spatial and temporal conditions there are some types of information that must be plugged into the LCA which are not well understood. Biofuel production takes place in an agricultural ecosystem comprised of many processes that are complex and difficult to predict. Accounting for this ecosystem complexity is the third challenge facing biofuel LCA.

Aspects of the challenge - For example, nitrous oxide emissions from soil are a significant source of GHG emissions in biofuel production but emission rates vary widely within microenvironments based on soil type, climate, and fertilizer regimes (Larson, 2006). The inherent complexity of the $\mathrm{N}_{2} 0$ emission relationship is a challenge to model. Soil carbon build up and loss is also difficult to model (Cheminfo, 2008).

Addressing the challenge - Improved soil and soil-gas modelling may reduce this challenge. In the meantime, LCA results should report the uncertainty in results that is introduced by variable ecosystem processes. The LCA conducted for this thesis includes an uncertainty analysis.

\subsubsection{Accounting for extremely complex and variable human processes}

The last major challenge to obtaining an accurate picture of the life cycle fossil and greenhouse gas costs of biofuel is integrating human processes into the account. The rise 
in use of biofuels has connections to environment policy, energy policy and food policy. The FAO (2007, p v) has described biofuel as being at the centre "of three of the world's greatest challenges - energy security, climate change, and poverty reduction". In this context the biofuel production process is particularly dynamic and subject to institutional pressures.

Aspects of the challenge - the problem of how to integrate linkages between the larger economy is considerable. Some argue that LCA results are meaningless without consideration of economic impacts (Delluchi, 2004). But the practical ability to integrate social and economic impacts of products into LCA is "fraught with difficulty" (Reap et al 2008 p. 295). The recent emergency debates and international attention surrounding food prices and the relationship to the biofuel demand for grain has shown the importance of not neglecting a wider evaluation of the impacts of biofuels. It is practical to isolate the environmental impacts of biofuel to the boundary of "plough to pump" but the question must be asked if the results from such assessments are failing in even the basic task to assess relative energy and GHG merits of alternative fuel choices.

For example, the potential for greenhouse gas emissions from land use change driven by bioenergy cropping is not well understood. Although, this impact has received more attention in the literature, the assumptions in most studies used are worst-case and difficult to prove. Fargione et al (2008) predict that potential clearing of U.S. grassland for ethanol production will release stored carbon and loss of carbon uptake resulting in a "carbon debt" that will take 93 years to recapture in agricultural cropping. Searchinger $e t$ 
al (2008) assume that any increase in ethanol production will lead to conversion of new agricultural land. They calculate that meeting US ethanol targets will lead to release of stored carbon and loss of carbon uptake leading to an overall $93 \%$ increase in greenhouse gas emissions compared to gasoline instead of the more commonly accepted figure of $20 \%$ savings.

On the other hand, others suggest that land use changes will be minimal and that demand for biofuel will be met mostly by increased productivity on existing land (e.g. Cheminfo 2008).

Addressing the challenge - integrating the relationship between use of biofuel and environmental impacts outside of the immediate system boundary in the LCA is a major challenge. In the case of land-use changes, the approach followed in this LCA is to rely on empirical evidence of past land use change to inform the decision on including this impact. One approach may be to monitor this variable other socio-economic changes. The continued challenge is identifying relevant changes and assessing interactions.

The best opportunities may lie in bringing in separate social and economic assessments to biofuel choices. Project based impact assessments methods typically require perspectives from multiple stakeholders and identification of potential impacts over time (Mitchell, 2002). These could be used in conjunction with LCA. 


\section{4. - Selecting the locations for study}

Ethanol use in Ontario is typical of North America and in Europe where ethanol is provided in a low-level blend with gasoline. A minimum 5\% ethanol content is mandated and blends of $10 \%$ ethanol are common at some gas stations. Higher $\mathrm{E}$ blends are emerging, but effectively unimportant in the province today with only 3 stations carrying E85, (National Ethanol Vehicle Coalition, 2008). ${ }^{3}$

The provincial government intends to more than double the volume of ethanol produced from 2005 levels (Govt Ontario, 2005, 2008) and the location of E5 production in Ontario is changing. The construction of an ethanol manufacturing plant in the eastern part of the province is pushing the industry to new regions. E5 fuel is made from the same raw materials (corn and crude oil) in Southern Ontario (S.Ont) and Eastern Ontario (E.Ont) but the locations of the sources for raw materials and of the intermediate steps in the E5 product life cycle are distinctly different (table 4.1).

Table 4.1 - Locations involved in production of E5 fuel in S.Ont and E.Ont

\begin{tabular}{|l|l|l|l|l|l|l|}
\hline $\begin{array}{l}\text { Ontario } \\
\text { region }\end{array}$ & $\begin{array}{l}\text { Crude Oil } \\
\text { Source }\end{array}$ & $\begin{array}{l}\text { Oil } \\
\text { refinery } \\
\text { location }\end{array}$ & $\begin{array}{l}\text { Corn } \\
\text { source }\end{array}$ & $\begin{array}{l}\text { Ethanol } \\
\text { plant } \\
\text { location }\end{array}$ & $\begin{array}{l}\text { Blending } \\
\text { location }\end{array}$ & $\begin{array}{l}\text { E5 retail } \\
\text { location }\end{array}$ \\
\hline $\begin{array}{l}\text { South } \\
\text { (S.Ont) }\end{array}$ & $\begin{array}{l}\sim 65 \% \text { from } \\
\text { W.Canada }\end{array}$ & $\begin{array}{l}\text { Five in } \\
\text { region most } \\
\text { along St. } \\
\text { Clair River }\end{array}$ & $\begin{array}{l}\text { Avg } 60 \\
\mathrm{~km} \\
\text { supply } \\
\text { radius }\end{array}$ & $\begin{array}{l}\text { St.Clair or } \\
\text { Chatham }\end{array}$ & $\begin{array}{l}\text { London or } \\
\text { Toronto } \\
\text { terminals }\end{array}$ & $\begin{array}{l}\text { S. and } \\
\text { central } \\
\text { Ontario }\end{array}$ \\
\hline $\begin{array}{l}\text { East } \\
\text { (E.Ont) }\end{array}$ & $\begin{array}{l}\text { Imported, } \\
\text { imost from } \\
\text { North Sea }\end{array}$ & $\begin{array}{l}\text { Two in } \\
\text { Montreal, } \\
\text { QC }\end{array}$ & $\begin{array}{l}60 \mathrm{~km} \\
\text { supply } \\
\text { radius } \\
\text { (likely) }\end{array}$ & $\begin{array}{l}\text { Johnstown } \\
\text { (Dec } \\
2008)\end{array}$ & $\begin{array}{l}\text { Ottawa or } \\
\text { Kingston } \\
\text { terminals }\end{array}$ & $\begin{array}{l}\text { E. and } \\
\text { Central } \\
\text { Ontario }\end{array}$ \\
\hline
\end{tabular}

${ }^{3}$ These three retailers were contacted to confirm availability. Only two had e- 85 for sale 
Ontario produces only about $0.05 \%$ of Canada's crude oil (CAPP, 2004), and for the purposes of this study, only crude oil imported from other parts of Canada and foreign sources will be considered. The source of crude oil depends on refining capacities that presently exist in the province. In E.Ont there are no crude oil refineries and the region relies on two refineries near Montreal (NRCan, 2005). In S.Ont, five crude oil refineries are the major sources of gasoline for the region and provide gasoline for eastern North America.

Recent estimates (Rau, 2008) state that $65 \%$ of the crude oil used to make gasoline in the Ontario refineries originates extracted in Western Canada and is a mixture of conventional crude oil and oil-sand derived synthetic crude and bitumen. In contrast, there is no use of Western Canadian crude to make gasoline in Quebec refineries, and the largest single source $(40 \%)$ is conventional light crude oil extracted in the European North Sea (Stats Can, 2008a).

In Ontario, $99.5 \%$ of the ethanol portion of ethanol blend gasoline is derived from corn. This feedstock is found in relative abundance in the province (table 4.2). The most productive region is in the south with $50 \%$ of total corn production (OMAFRA, 2007a).

Discussions with ethanol plant spokespeople and corn brokers revealed that the current and future average corn supply radius is between 60 and $100 \mathrm{~km}$ in both regions. In the Southern region farms in Lambton county provides most (25-30\%) corn to the ethanol 
plant (McKillop, 2008). The eastern ethanol plant is not yet completed but representatives indicated that corn will be received from farms in counties around the plant. Because of the volumes of corn needed, production of ethanol takes corn from many hundred farms each with different yields, inputs and management practices (Armstrong, 2008).

Table 4.2 - Grain corn production in Ontario 2005 - 2008 (Statistics Canada, 2006a,07,08a)

$\begin{array}{lcccc} & 2005 & 2006 & 2007 & 2008 \text { (intended) } \\ \begin{array}{l}\text { Total crop area } \\ \text { Seeded (1,000 ha) }\end{array} & 2,448 & 2,475 & 2,456 & 2,476 \\ \begin{array}{l}\text { Total corn seeded } \\ \begin{array}{l}(1000 \text { ha) } \\ \text { Corn as a \% of total }\end{array}\end{array} & 647.5 & 663.7 & 849.8 & 739.6 \\ \text { seeded area } & 27 \% & 35 \% & 30 \% \\ \text { * includes wheat, oats, barley, rye, mixed grains, canola, grain corn, fodder corn, } \\ \text { soybeans, white and coloured beans }\end{array}$

The blending of ethanol with gasoline currently takes place in terminals located close to major markets. There are approximately 20 gasoline terminals in Ontario (NPRI, 2007). There are four in Eastern Ontario in Ottawa and Kingston and approximately a dozen in southern Ontario and Toronto area. Representatives of the ethanol plant visited in S.Ont said ethanol was usually mixed with gasoline in a London terminal but also was trucked to Toronto area terminals (Clark, 2008).

It is clear that the geographic scale of E5 production extends well-past the borders of the sub-regions and those of Ontario. The crude oil/gasoline part of the product crosses continents, while the corn/ethanol/E5 blending part of the life-cycle is usually constrained 
to several hundred $\mathrm{km}$ at most. ${ }^{4}$ The relatively local nature of the corn-ethanol-blending part of the life-cycle suggests a sub-provincial focus for the E5 LCA is appropriate. However, it is important to realize that the gasoline portion of E5 derives from crude oil extracted in locations outside the province and to incorporate this fact into the LCA.

\subsubsection{LCA literature for study location and the GHGenius model}

Natural Resources Canada (2003) and Agriculture Canada (Levelton et al., 2000) have both commissioned consultant studies on Ontario corn-ethanol. The 2000 report used southern Ontario data and concluded that ethanol produced in Ontario in the year 2000 had a net positive energy balance, and that blending $10 \%$ ethanol into gasoline would achieve $3.9 \%$ greenhouse gas savings compared to conventional gasoline produced in the same year. The authors predicted that by the year 2010, GHG savings would rise to $4.6 \%$ because of increased efficiencies in ethanol plants.

Zang et al (2007) completed a LCA assessment of cellulose bioenergy options in Ontario and concluded that using solid biomass to replace coal was the most cost effective. Sampson (2008) in a trade/NGO publication examined greenhouse gas saving potential and costs for Ontario for different feedstocks including corn ethanol. Both authors relied on the federal government GHGenius model for Ontario data.

The GHGenius model was developed by the same author (S\&T consultants) of the 2000 and 2003 study for the federal government. S\&T added Canadian data to the pathways of a life cycle emissions model created by Delucchi (2002) and continue to update the

\footnotetext{
${ }^{4}$ A certain portion of ethanol used in Ontario is imported from outside the province. Data is hard to come by but the source of ethanol imports is likely northern and central U.S. and possibly Brazil (Labelle, 2008)
} 
project. The majority of values for corn-ethanol production inputs are from 1994 and 1999 data sets. The model incorporates "efficiency factors" to adjust the base year data to the year to which the user selects.

The GHGenius model provides energy balances, greenhouse gas emissions and emissions of other air pollutants for approximately 100 fuel, feedstock and vehicle pathways. The model can be deployed to provide results by varying parameters such as crude oil type, corn yield, fertilizer inputs, and refinery energy use (GHGenius, 2005)

In the GHGenius model an "input" sheet allows user to choose region of North America (for Canada choices are West, Central, East) and to input specific values for items such as transport distances, crude oil split, corn farming data, and ethanol plant data. In the case of ethanol plant data only one of the inputs (diesel use) can be changed on the input sheet. The remaining major inputs of natural gas, electricity use, yield of ethanol per corn, co-product yield are derived from other parts of the spreadsheet. The user can change these but requires familiarity with layout of model and of spreadsheets in general. In other words, the GHGenius model is not well suited to incorporating local data. For the corn farming stage the situation is different, each of the major data points (nitrogen fertilizer rate, phosphate and potassium fertilizer, total diesel fuel use, total electricity use, harvest yield) can be changed on the input sheet. The model requires the user to have values expressed per tonne of corn and requires summing up of all activities (e.g., total diesel, total natural gas) but in theory can accommodate local values. For crude oil, the user can select any combination of five types (light onshore, offshore, heavy, bitumen 
and synthetic). The GHGenius model is a valuable tool in determining life-cycle fossil fuel use and GHG emissions and the gasoline portion of the E5 products assessed in this research are taken directly from GHGenius outputs. ${ }^{5}$

\subsection{Developing the S.Ont case study}

Southern Ontario (alternatively South-Western Ontario) extends west to the US border and east to the Niagara River, and from Lake Erie in the south to southern Lake Michigan in the North (figure 4.1) . OMAFRA (2007a) includes ten sub provincial administrative districts in its' grouping of the region.

Oil infrastructure: S.Ont is an oil refining centre and all of Ontario's oil refineries are located in this region, most along the St. Clair River close to the city of Sarnia in Lambton County. The oil industry is historically very important in this region which encompasses the community of Petrolia, the location that claims credit with starting the world's oil industry in 1858 . The prevalance of oil and other petrochemical use has earned the area the name "chemical valley".

Ethanol infrastructure: The region has an established ethanol industry. The Greenfield Chatham plant in Chatham county is a decade old and the two year old St. Clair plant is the largest in the province with plans to double in size. It is located in the township of St.Clair about five kilometres east of the community of Corunna and the St. Clair River. Corn is currently delivered by truck, but the plant has tracks to accommodate rail cars.

\footnotetext{
${ }^{5}$ As discussed in chapter 5 the use of the GHGenius model for the gasoline portion of the E5 product introduces some questions around data quality and system boundaries.
} 
Agricultural characteristics: Lambton county is the location of the major ethanol plant in the region and supplies the greatest portion of corn for that plant. Lambton is one of the best in the province for growing corn as indicated by heat units and average yields (table 4.2). Note that heat units are an index of average temperature use for growing warm season crops. A general rule is the more heat units the easier to grow corn - for reference the value for E.Ont is 2700 - section 4.3). The county is relatively rural and has more people employed in agriculture than the provincial average and in the E.Ont counterpart (table 4.3). Approximately two-thirds of farms grow grain but livestock farming is also prevalent and mixed grain and livestock farms are common. There are a significant number of large farms and more than a third of the county's farms have revenues of $\$ 1$ million.

Table 4.3 - Agricultural characteristics of Lambton county

\begin{tabular}{|l|l|}
\hline Characteristic & Lambton county \\
\hline Population & 128,204 (Stats Can, 2006b) \\
\hline \% labour in agriculture and other resource industries & $7 \%$ (Stats Can, 2006b) \\
\hline Corn heat units & 3300 (OMAFRA, 2007) \\
\hline Rainfall mm & 732.6 (Env, Canada 2008) \\
\hline Number of farms & 2,281 (OMAFRA, 2007) \\
\hline$\%$ of farms growing grain & $65 \%$ (Stats Can 2001) \\
\hline \% of farms with revenues greater than \$1 million & $38 \%$ (OMAFRA 2007) \\
\hline Biggest revenue source & Hogs (OMAFRA 2007) \\
\hline Total cropland (ha) & 203,737 (OMAFRA 2007) \\
\hline Most common crop (with rank of corn) & Soybeans (grain corn 3rd) \\
\hline \% no-till & $44 \%$ (Stats Can 2001) \\
\hline Corn yield (avg) (bushels/acre) & 161 (OMAFRA, 2006) \\
\hline Total corn harvested (tonnes) & 302,200 \\
\hline
\end{tabular}



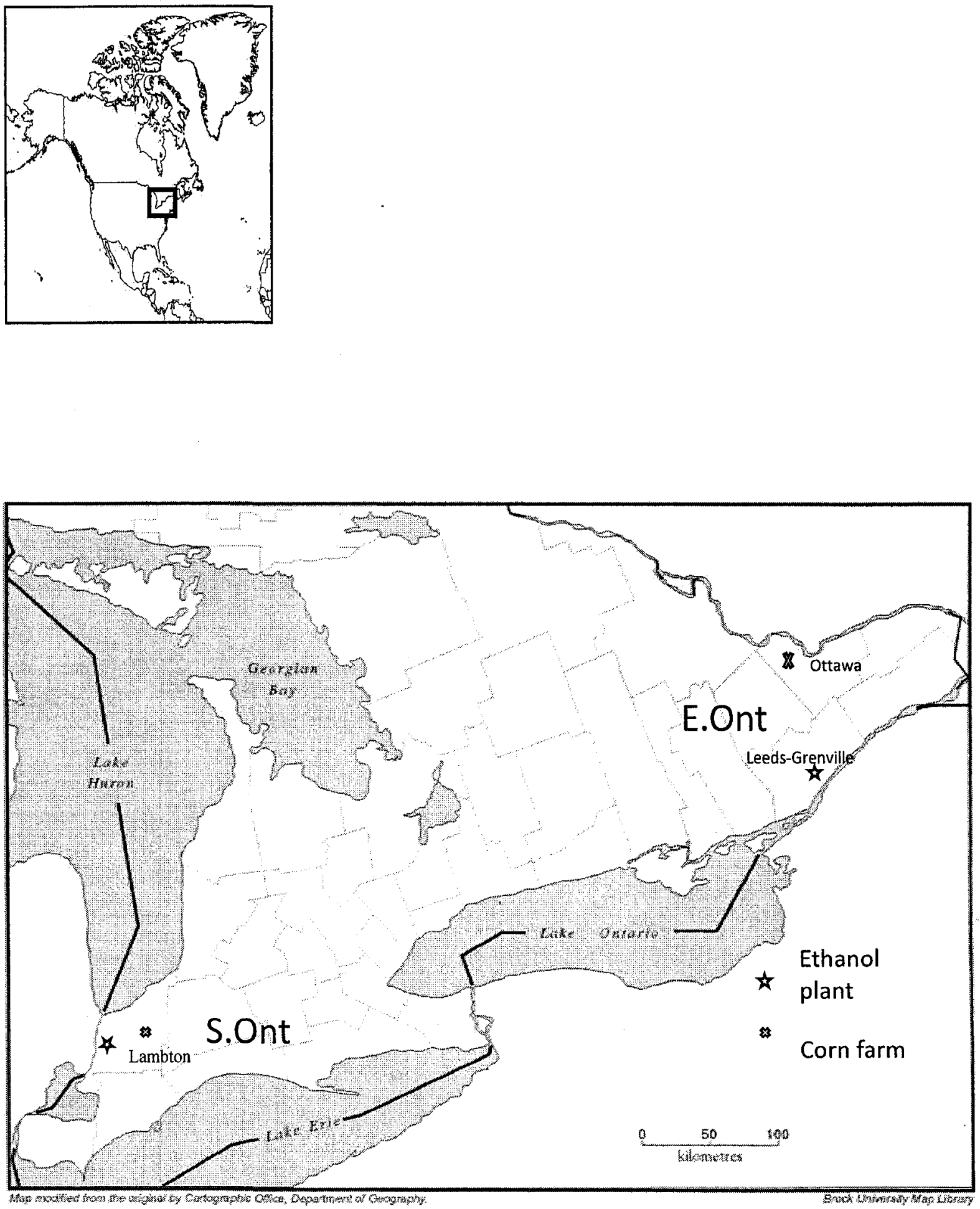

Figure 4.1 - Map of S.Ont and E.Ont regions and main case study sites 


\subsubsection{S. Ont case}

A case study was developed that considers the unique features of the regions. The agricultural features most important to reflect in the case study farm are corn yield and tillage type. Yield is an indicator of how productive the region is and tillage type is hypothesized to be a good indication of willingness to adopt new farm practices. The case farm reflects regional norms for these two characteristics and provides some confidence of regional representation (although not as much confidence as the highly impractical sampling of 200 of the 2,200 farms in the county might have been). In the case of the ethanol plant, the choice of data source was more straightforward. St. Clair ethanol plant is the largest and newest of the two ethanol plants and was chosen. This plant was visited but unfortunately site specific data was not available and proxy data from an ethanol plant in Varennes, QC was used instead.

For the crude oil recovery stage, synthetic crude was chosen. This form of crude oil makes up approximately $15 \%$ of total oil used in Ontario refineries and about $25 \%$ of Western Canadian oil imports (Stats Can 2008a). Conventional light crude is more commonly used ( $\sim 60 \%$ of total) but the share of synthetic crude is rising as conventional oil reserves in Canada decline (CAPP, 2006, GHGenius 20076). The choice of synthetic crude has the benefit of being in between conventional crude and the more highly polluting bitumen also used in Ontario refineries, and provides a valuable contrast with the conventional crude oil of the E.Ont case.

\footnotetext{
${ }^{6} \mathrm{GHGenius}$ assumes $42 \%$ syncrude for Ontario refineries for model year 2007
} 
The remainder of the case study features rely on generic descriptions of the activities in the E5 life cycle. Data for the LCA inventory is taken from databases derived from census or survey data. The implications of the generic nature of this data on the goal and scope of the LCA is discussed in section 5.2.

\subsection{Developing the E.Ont case study}

Eastern Ontario is the region bounded by the Quebec border to the east and to the north, the St. Lawrence River to the south and extends as far as Kingston to the East (see figure 4.1). OMAFRA (2007b) counts seven counties in this region. The eastern ethanol plant is found a few km away from the St. Lawrence River in Johnstown, Leeds and Grenville County. Ottawa is the major urban centre of the region and also a significant corn producing region

Oil infrastructure: Eastern Ontario does not have any refineries and refined gasoline is supplied to the region from Montreal through the Trans Northern Pipeline which runs to Kingston with a spur to Ottawa (Rau, 2008 pers comm). Ottawa has a product terminal where gasoline and (likely) ethanol will be stored before distributed to gas stations

Ethanol infrastructure: A 200 million litre ethanol plant is under construction in Johnstown. The plant is located in the township of Edwardsburgh/Cardinal and county of Leeds-Grenville. It is served by a four lane highway to the North to Ottawa and is few $\mathrm{km}$ from the St. Lawrence River and the Port of Prescott which includes a 150,000 tonne grain elevator. The closest existing ethanol plant is $200 \mathrm{~km}$ away in Varennes, QC. 
Agricultural characteristics: The Leeds-Grenville county does not produce enough corn to meet the needs of the 200 million litre plant (approximately 80,000 tonnes of corn a year), so a neighboring area was also reviewed to help select an appropriate E.Ont case farm. The Municipality of Ottawa produces about three times as much corn (table 4.4). Note that grain farming is only practiced by less than a fifth of farms and dairy farming and growing hay is common in both of these sub-regions. Corn yields are lower and there are significantly less million dollar farms than was seen in the S.Ont region.

Table 4.4: Agricultural characteristics of key E.Ont corn supplying regions (same sources as table 4.3 )

\begin{tabular}{|l|l|l|}
\hline & $\begin{array}{l}\text { Leeds and Grenville } \\
\text { county }\end{array}$ & Ottawa Division \\
\hline Population & 99,206 & 812,129 \\
\hline$\%$ of experienced labour in agriculture & $3.7 \%$ & $1.0 \%$ \\
\hline Heat units & 2700 & 2700 \\
\hline Rainfall mm & 763.3 & 732 \\
\hline Number of farms & 1,303 & 1,267 \\
\hline$\%$ of farms growing grain & $9 \%$ & $16 \%$ \\
\hline$\%$ of farms with revenues $>\$ 1$ million & $15 \%$ & $24 \%$ \\
\hline Biggest revenue source & Dairy & Dairy \\
\hline Total cropland (ha) & 61,801 & 78,655 \\
\hline Most common crop (rank of corn) & Hay (grain corn $\left.2^{\text {nd }}\right)$ & Hay (grain corn $\left.3^{\text {rd }}\right)$ \\
\hline$\%$ no-till & $19 \%$ & $19 \%$ \\
\hline Corn yield (avg) (bushels/acre) & 143 & 151 \\
\hline Total corn harvested (tonnes) & 54,100 & 140,800 \\
\hline
\end{tabular}

\subsubsection{E. Ont Case study}

The same process used to develop the S.Ont case was followed for the E.Ont case (table 4.4 for summary). The eastern ethanol plant has yet to be built, and therefore some "educated assumptions" were made for the features characterizing the eastern fuel ethanol supply chain. For example, an Ottawa area farm which had yield and tillage practices typical of the anticipated supply sub-regions was selected. The producer 
indicated that he would be selling to the refinery. A working ethanol plant in Varennes, QC owned by the same company as is constructing the E.Ont plant and built using the same technology was visited and the production values from this facility are used in the LCA evaluation.

The presumed blending location of Ottawa was used as it is closer to the ethanol plant than the Kingston terminal. The most common source of crude oil was selected and a data set that includes Montreal area refineries was used. For the retail and use life cycle stages the features of the case study are identical to that of the S.Ont case as there is no apparent regional distinction for these stages.

\subsection{Developing the generic Ontario base case and gasoline cases}

A third case study, Generic Ontario (Gen.Ont) was constructed relying on published data for provincial averages or common practice information found in the literature. This surveillance level information represents the common form of data used in biofuel LCAs found in the literature. As such this case provides a base from which to compare the divergence in LCA results when focusing on a local (i.e. the S.Ont case and the E.Ont case) scale.

In order to assess the fossil fuel and greenhouse gas savings versus gasoline, a gasoline case for the same location as the E5 case is also required. Since the life cycle for E5 fuel comprises the production of gasoline, these features can be used for the $100 \%$ gasoline case. The three additional gasoline fuel production cases use the same characteristics of stage 3 (crude oil extraction) to stage 7 (use in vehicle) of the E5 cases for S.Ont, E.Ont 
and Gen.Ont (table 4.4). The only changes required are deleting ethanol transport to storage terminals in stage 5 (storage and blending) and adjusting for a different calorific content of the final fuel in the use stage 7 (use in vehicle).

\subsection{Case study summary}

From table 4.4 there are many similarities across the two regional case studies and the generic provincial study. These include identical fuel retail conditions and vehicle characteristics. Equally important are the differences across the case studies, key among these are different corn yields and farming practices and different crude oil sources. Note the column "required to complete LCA" refers to the type of data needed for each stage (site specific primary data or more general secondary data). Recall that the foreground process are those for which primary data is collected (Curran, 2007, Guinee, 2004). 
Table 4.5. Summary of how regional and case study features match up

\begin{tabular}{|c|c|c|c|c|c|c|c|c|}
\hline \multirow{2}{*}{$\begin{array}{l}\text { Life } \\
\text { cycle } \\
\text { stage }\end{array}$} & \multirow{2}{*}{$\begin{array}{l}\text { Box } \\
\text { in } \\
\text { Fig. } \\
2.1\end{array}$} & \multirow{2}{*}{$\begin{array}{l}\text { Required } \\
\text { data }\end{array}$} & \multicolumn{2}{|c|}{ S.Ont } & \multicolumn{2}{|c|}{ E.Ont } & \multicolumn{2}{|c|}{ Gen.Ont } \\
\hline & & & $\begin{array}{l}\text { Regional } \\
\text { features }\end{array}$ & Case study & $\begin{array}{l}\text { Regional } \\
\text { features }\end{array}$ & Case study & $\begin{array}{l}\text { Provincial } \\
\text { features }\end{array}$ & Case study \\
\hline $\begin{array}{l}\text { Farm } \\
\text { corn }\end{array}$ & $\# 1$ & $\begin{array}{l}\text { Primary, } \\
\text { site } \\
\text { specific }\end{array}$ & $\begin{array}{l}\text { Corn yield } 160 \\
\text { bushels/ac } \\
\text { No-till } \\
\text { cultivation } \\
2,280 \text { farms in } \\
\text { county, grain } \\
\text { farming } \\
\text { common }\end{array}$ & $\begin{array}{l}\text { Yield is } 10.5 \\
\text { tonnes/ha } \\
(167 \mathrm{~b} / \mathrm{ac}) \\
\text { No-till } \\
\text { Grain farm } \\
\text { that supplies } \\
\text { St.Clair } \\
\text { ethanol plant }\end{array}$ & $\begin{array}{l}\text { Corn yield } \\
\text { between } 140 \\
\text { and } 150 \mathrm{~b} / \mathrm{ac} \\
\text { Conventional } \\
\text { or reduced } \\
\text { cultivation } \\
\text { Grain farms } \\
\text { rare }\end{array}$ & $\begin{array}{l}\text { Yield is } 8.85 \\
\text { tonnes/ha (141 } \\
\text { b/ac) } \\
\text { Reduced till } \\
\text { Grain farm } \\
\text { planning to } \\
\text { supply plant }\end{array}$ & $\begin{array}{l}\text { Corn yield } 8.97 \\
\text { tonnes / ha } \\
\text { Conventional } \\
\text { tillage in over } \\
\text { half of area } \\
\text { (Stats Can 2001) }\end{array}$ & $\begin{array}{l}\text { Yield of } 8.97 \\
\text { and } \\
\text { conventional } \\
\text { tillage }\end{array}$ \\
\hline $\begin{array}{l}\text { Manuf. } \\
\text { ethanol }\end{array}$ & $\# 2$ & $\begin{array}{l}\text { Primary, } \\
\text { site } \\
\text { specific }\end{array}$ & $\begin{array}{l}\text { Two dry mill } \\
\text { ethanol plants } \\
\text { in region }\end{array}$ & $\begin{array}{l}\text { Largest plant } \\
\text { selected but } \\
\text { not used (see } \\
\text { text) }\end{array}$ & $\begin{array}{l}\text { One ethanol } \\
\text { plant under } \\
\text { construction }\end{array}$ & $\begin{array}{l}\text { Closest ethanol } \\
\text { plant used, } \\
\text { with same } \\
\text { owner, same } \\
\text { technology }\end{array}$ & $\begin{array}{l}\text { Three dry mills } \\
\text { in province }\end{array}$ & $\begin{array}{l}\text { Typical } \\
\text { performance } \\
\text { from plant } \\
\text { designer }\end{array}$ \\
\hline $\begin{array}{l}\text { Reco- } \\
\text { ver oil }\end{array}$ & $\# 3$ & $\begin{array}{l}\text { Primary or } \\
\text { secondary }\end{array}$ & $\begin{array}{l}65 \% \text { western } \\
\text { Canada oil }\end{array}$ & $\begin{array}{l}\text { Synthetic } \\
\text { crude from } \\
\text { W. Canada } \\
\text { chosen, }\end{array}$ & $\begin{array}{l}\text { Offshore North } \\
\text { sea oil is single } \\
\text { largest source }\end{array}$ & $\begin{array}{l}\text { Light crude } \\
\text { from North } \\
\text { Sea }\end{array}$ & $\begin{array}{l}\text { Crude split } \\
\text { defaults ( } 41 \% \\
\text { light, } 42 \% \\
\text { syncrude, } 16 \% \\
\text { bitumen) }\end{array}$ & $\begin{array}{l}\text { Provincial } \\
\text { mix used }\end{array}$ \\
\hline $\begin{array}{l}\text { Refine } \\
\text { to gas }\end{array}$ & $\# 4$ & $\begin{array}{l}\text { Primary or } \\
\text { secondary }\end{array}$ & $\begin{array}{l}\text { Four refineries } \\
\text { in region, mix } \\
\text { of ages and } \\
\text { capabilities }\end{array}$ & $\begin{array}{l}\text { Average data } \\
\text { for all Ont } \\
\text { refineries }\end{array}$ & & $\begin{array}{l}\text { Average data } \\
\text { for all Eastern } \\
\text { Canada } \\
\text { refineries }\end{array}$ & $\begin{array}{l}\text { Five refineries } \\
\text { in province }\end{array}$ & $\begin{array}{l}\text { Average data } \\
\text { for all Ont. } \\
\text { refineries }\end{array}$ \\
\hline
\end{tabular}


Table 4.5 Summary of regional features match up with case study chosen for the LCA (continued)

\begin{tabular}{|c|c|c|c|c|c|c|c|c|}
\hline \multirow{2}{*}{$\begin{array}{l}\text { Life } \\
\text { cycle } \\
\text { stage }\end{array}$} & \multirow{2}{*}{$\begin{array}{l}\text { Box } \\
\text { in } \\
\text { Fig. } \\
2.1\end{array}$} & \multirow{2}{*}{$\begin{array}{l}\text { Required } \\
\text { data }\end{array}$} & \multicolumn{2}{|c|}{ S.Ont } & \multicolumn{2}{|c|}{ E.Ont } & \multicolumn{2}{|c|}{ Gen.Ont } \\
\hline & & & $\begin{array}{l}\text { Regional } \\
\text { features }\end{array}$ & Case study & $\begin{array}{l}\text { Regional } \\
\text { features }\end{array}$ & Case study & $\begin{array}{l}\text { Provincial } \\
\text { features }\end{array}$ & Case study \\
\hline $\begin{array}{l}\text { Blend } \\
\text { E5 \& } \\
\text { gas }\end{array}$ & $\# 5$ & $\begin{array}{l}\text { Primary or } \\
\text { secondary }\end{array}$ & $\begin{array}{l}\text { Takes place } \\
\text { close to major } \\
\text { urban markets } \\
\text { in London or } \\
\text { Toronto } \\
\text { terminals }\end{array}$ & $\begin{array}{l}\text { London, ON } \\
\text { terminal } \\
\text { chosen for } \\
\text { calculating } \\
\text { distance, and } \\
\text { N. Am } \\
\text { terminal data }\end{array}$ & $\begin{array}{l}\text { Four terminals } \\
\text { in region, three } \\
\text { in Ottawa }\end{array}$ & $\begin{array}{l}\text { Ottawa, ON } \\
\text { terminal } \\
\text { chosen for } \\
\text { calculating } \\
\text { distance, } \\
\text { N.Am terminal } \\
\text { data used }\end{array}$ & $\begin{array}{l}20 \text { terminals in } \\
\text { province }\end{array}$ & $\begin{array}{l}225 \mathrm{~km} \\
\text { ethanol, } 297 \\
\mathrm{~km} \text { gasoline } \\
\text { chosen, } \\
\text { N.Am. } \\
\text { terminal data } \\
\text { used }\end{array}$ \\
\hline Retail & $\# 6$ & $\begin{array}{l}\text { Primary or } \\
\text { secondary }\end{array}$ & $\begin{array}{l}\text { Hundreds of } \\
\text { gas stations in } \\
\text { region } \\
\text { virtually } \\
\text { identical } \\
\text { processes }\end{array}$ & $\begin{array}{l}\text { Generic gas } \\
\text { station data } \\
\text { chosen using } \\
\text { US Census } \\
\text { data }\end{array}$ & $\begin{array}{l}\text { Hundreds of } \\
\text { gas stations in } \\
\text { region } \\
\text { virtually } \\
\text { identical } \\
\text { processes }\end{array}$ & $\begin{array}{l}\text { Generic gas } \\
\text { station data } \\
\text { chosen using } \\
\text { US Census } \\
\text { data }\end{array}$ & $\begin{array}{l}\text { Hundreds of gas } \\
\text { stations in } \\
\text { region } \\
\text { Virtually } \\
\text { identical } \\
\text { processes }\end{array}$ & $\begin{array}{l}\text { Generic gas } \\
\text { station data } \\
\text { chosen using } \\
\text { US Census } \\
\text { data from } \\
\text { GHGenius } \\
\text { database }\end{array}$ \\
\hline $\begin{array}{l}\text { Use of } \\
\text { E5 }\end{array}$ & $\# 7$ & $\begin{array}{l}\text { Primary or } \\
\text { secondary }\end{array}$ & $\begin{array}{l}\text { Thousands of } \\
\text { vehicles in } \\
\text { region vary in } \\
\text { size and age }\end{array}$ & $\begin{array}{l}\text { Generic light } \\
\text { duty vehicle } \\
\text { with fuel } \\
\text { economy } \\
\text { values from } \\
\text { Stats Can }\end{array}$ & $\begin{array}{l}\text { Thousands of } \\
\text { vehicles in } \\
\text { region vary in } \\
\text { size and age }\end{array}$ & $\begin{array}{l}\text { Generic } \\
\text { Canadian light } \\
\text { duty vehicle } \\
\text { with fuel } \\
\text { economy } \\
\text { values from } \\
\text { Stats Can }\end{array}$ & $\begin{array}{l}\text { Thousands of } \\
\text { vehicles in } \\
\text { region vary in } \\
\text { size and age }\end{array}$ & $\begin{array}{l}\text { Generic } \\
\text { Canadian } \\
\text { light duty } \\
\text { vehicle with } \\
\text { fuel economy } \\
\text { values from } \\
\text { Stats Can }\end{array}$ \\
\hline
\end{tabular}


In total, the case studies provide six distinct products to subject to the life cycle assessment.

\begin{tabular}{|l|l|l|}
\hline E.Ont E5 fuel & S.Ont E5 fuel & Gen.Ont. E5 fuel \\
\hline E.Ont gasoline & S.Ont gasoline & Gen.Ont gasoline \\
\hline
\end{tabular}

\subsection{1...Sites visits and information interviews}

Throughout the winter and spring of 2008 , four site visits were conducted to gather data for this project. The aims of these visits were 1) to observe and accurately represent the production process and 2) to collect numerical values for use in the LCA:

- Varennes, Quebec, Greenfield ethanol plant, February 21, 2008. A tour of the ethanol plant was conducted with the plant manager who also provided estimates of daily inputs and product flows.

- S.Ont (St. Clair, Suncor) ethanol plant, April 16, 2008. A tour of the ethanol plant was conducted with the quality control manager.

- S.Ont case farm, April 16, 2008. An interview was held with a Lambton County corn producer who stores and supplies grain to a broker, who in turn supplies the St.Clair ethanol plant. The producer supplied estimates of inputs and field activities for growing corn over the past 3 years.

- E.Ont case farm, April 29, 2008. An interview was held with an Ottawa area corn producer who currently supplies a corn starch facility close to the ethanol plant and intends to supply grain to the Johnstown ethanol plant. The producer supplied estimates of inputs and field activities for growing corn over the past 3 years. 
The names of these key participants are not revealed as part of the data sharing agreement to protect the identities of individuals. Corn producers were recruited through an introduction from a corn specialist with OMAFRA who was asked to find farms that practicing the same form of tillage as the in the majority of the county and with yields close to the county average. Ethanol plant interviews were arranged by direct contact with the ethanol plant or corporate communication representatives. Donuts were purchased and provided to participants, no other compensation was offered. Interviews took place at the place of work and ranged from 1.5 to 2.5 hours in length. Consent forms were provided to participants who signed consent to use the data in this project (Appendix C).

The corn producer interviews were guided by a data table, shared before the interview took place (Appendix D, table D.1). The structure of the table was checked with an OMAFRA corn specialist and with the corn producer to ensure a complete set of inputs would be collected. Follow-up calls were required to confirm some details. The ethanol plant manager interviews were also guided by a data table (Appendix D, table D.2), shared beforehand and developed after initial discussion with the plant manager. Note that the S Ont ethanol plant did not share input and output details.

Over the period November 2007 to August 2008 several other informants provided background information on the ethanol and oil industry and in some cases specific details of the supply chain portrayed in the case studies. The main purpose of these discussions 
was to help in scoping the LCA. These individuals represented both industry and government and allowed for a variety of perspectives to underly the choices made in designing the LCA for each case study.

Table 4.6 - Informants helping to scope the study

\begin{tabular}{|l|l|}
\hline Position and organization & Information provided \\
\hline $\begin{array}{l}\text { Communications Coordinator, } \\
\text { Greenfield Ethanol }\end{array}$ & $\begin{array}{l}\text { Corn supply requirements for Greenfield and for } \\
\text { Johnstown plant }\end{array}$ \\
\hline Analyst, NRCan & Government work on regional variation in LCAs \\
\hline Scientist, Ag Canada & $\begin{array}{l}\text { Ag census data (1996 and 2001) by soil landscape } \\
\text { classification }\end{array}$ \\
\hline $\begin{array}{l}\text { Representative, London } \\
\text { Agricultural Commodities }\end{array}$ & Corn supply information for southern plant \\
\hline Scientist, Ag Canada & Energy analysis of farming, machinery lifespans \\
\hline $\begin{array}{l}\text { Economist, Agriculture } \\
\text { Canada }\end{array}$ & Government work on regional variation in LCAs \\
\hline Developer, GHGenius & Sources of data, structure of GHGenius model \\
\hline Analyst, NRCan & Oil refining infrastructure in Ontario and Quebec \\
\hline $\begin{array}{l}\text { Corn Specialist, Ontario } \\
\text { Ministry of Food and Rural } \\
\text { Affairs }\end{array}$ & $\begin{array}{l}\text { Recruited corn producers, agronomic details, reviewed } \\
\text { flow diagrams and data collections sheets }\end{array}$ \\
\hline $\begin{array}{l}\text { Communications, Suncor } \\
\text { Energy Ltd }\end{array}$ & Corn supply requirements for southern ethanol plant \\
\hline
\end{tabular}

\subsubsection{Implications of employing the case studies}

The central thrust of this research is a contrast of fossil fuel and GHG emissions from E5 fuel production in different parts of Ontario. Two regions that are, or will be, active in the industry were chosen for study.

From this basis a choice had to be made between using (or developing) regional production data or focusing instead on specific case studies. The main reason for employing individual case studies instead of county based data was to be able to model the detailed processes that are involved in the E5 production process. For example, there 
are hundreds of suppliers of corn to the ethanol process and each has variable production inputs. Detailed regional inventory data does not exist for each step, and developing such a data set is not only impractical but would involve inevitable aggregating of data that could mask differences that are only apparent with a site specific comparison. Furthermore as discussed in section 3.4, detailed unit-process level data is a requirement of LCA that is often absent in biofuel LCA. For these three reasons a case study approach is a better choice for the research objectives.

The difficulty with following the case study approach is that it is impossible to claim that the case is statistically representative of the region. It was shown in earlier sections how every effort was made to select a case study that shares some key features of the region. In some instances, the case study will be very good at representing the region (e.g., when one of two ethanol plants in the region is used), in other instances representation is less certain (e.g., there is no guarantee that the S.Ont case farm is similar to the 2,200 other farms in the immediate area).

Using case studies for the ethanol manufacturing stage should provide regional representation for this life cycle stage. Yet the plants were not anticipated to show much divergence in production values in any case. In both the southern and eastern supply regions the ethanol plant are newly constructed. The St. Clair (S.Ont) plant was built in 2006 and the Johnstown plant (E.Ont) is expected to be completed by end of 2008. Both plants have been designed and built (or are being built) by ICM Inc., an engineering company involved in two-thirds of ethanol plants in North America (ICM, 2008) that offers what the St. Clair plant representatives called a "turn-key" product. In other words, 
the ethanol plant owner contracts ICM to design, build and configure a standard dry-mill ethanol plant that is ready for immediate use by the owner.

Both of the ethanol plants visited for this project (St. Clair and Varennes) had been built be ICM and had strikingly similar layout . The receiving area, fermentation tanks, distillation towers, dryers and associated components were all in the same configuration. Both were based on a "batch" process where ethanol fermented in batches in one of three or four tanks and when a batch is completed the tank is cleaned and returned to use. Both were "closed loop" zero effluent process using a "bio-methanotor" to treat and clean process water, both captured $\mathrm{CO}_{2}$ and sold to a $\mathrm{CO}_{2}$ bottling company.

The case farms provide the greatest difficulty for regional representation. It is almost certain that features of the farm used in the S.Ont case will be found in the E.Ont region and vice versa. However, a valid comparison can be made between the cases for the reason that it will help reveal the extent that changes in location (if not region) can impact E5 energy use and emissions.

\subsubsection{Implications of management styles}

In each of the cases where site specific data is collected direct from individuals, some observations on the influence of management styles are worth noting. The corn producers interviewed for this study showed different farming behavior. The southern producer was younger, quicker to adopt new technology and a more complete record keeper than the eastern producer. This has implications not only for data quality, but also for understanding the reasons for variability in E5 production. Some individuals will 
experiment more readily with practices that to change productivity, and thus those production sites will have a different fossil fuel and GHG profiles.

Differences between the ethanol plants in management choices and operational decisions were harder to judge. The production process is standard but it is clear that human influenced differences in monitoring, cleaning of tanks, quality controls for corn, and maintenance regimes could change the fossil energy and GHG profile of the plant. 


\section{Implementing the research framework}

Several related activities are brought together in this thesis which centres on the design and implementation of a life cycle assessment of Ontario fuel made in two places. To help guide the reader, figure 5.1 maps out the overall research framework and connections between specific sections of the document.

The bidirectional arrows in figure 5.1 indicate that the implementation of the LCA was iterative and that findings presented in other sections were re-examined and the design of the LCA tweaked. For example, setting the boundary for what activities were included in the model required a return to the biofuel LCA literature in section three. Assessing confidence in the LCA's ability to provide accurate results meant checking key variables identified in results section six. Lastly, key parts of the data collection or "inventory" part of the LCA are presented in section four and re-examined throughout the process.

Conventionally, there are four distinct phases to an LCA (figure 5.2). The International Organizations for Standardization (ISO) document 14044 "Environmental management Life cycle assessment - Requirements and guidelines" provides rules for each phase. For this thesis these rules have been developed into four checklist tables that introduce each of the four major phases: 5.1 goal and scope definition, 5.2 inventory analysis, 5.2 impact assessment, and 5.4 interpretation. 
Section 2 - Building the foundation

- establish importance of fossil fuel and GHG savings from biofuel

- describe E5 product, and identify scope of data required for research

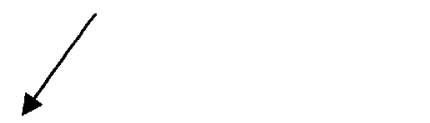

Section 3-Assessing the state of knowledge

- identify tools capable of representing biofuel production process

- consider past findings

- identify challenges to use of LCA for biofuels and ways to address

Section 4 - Selecting the focus

- establish S.Ont and E.Ont region characteristics and relevance

- construct the case studies and gathering the data
Section 5.6 and 6.6 - How well did the LCA technique tool function? (obj \#2)

- lessons learned applying LCA

- provincial $\mathrm{v}$ regional assessments
Section 5 - Implementing the research framework

- apply LCA to case study biofuels

- gauge process

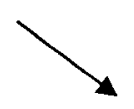

Section 7 - Summing up

Section 6.1 to 6.6 - S.Ont / E.Ont compared (objective \#1)

- identify extent of inter-regional variation in E5 fossil fuel and GHG savings versus gasoline

- identify areas to improve E5 footprint

- review objectives, major findings and recommended new research

Figure 5.1 - Research activities and presentation in thesis 


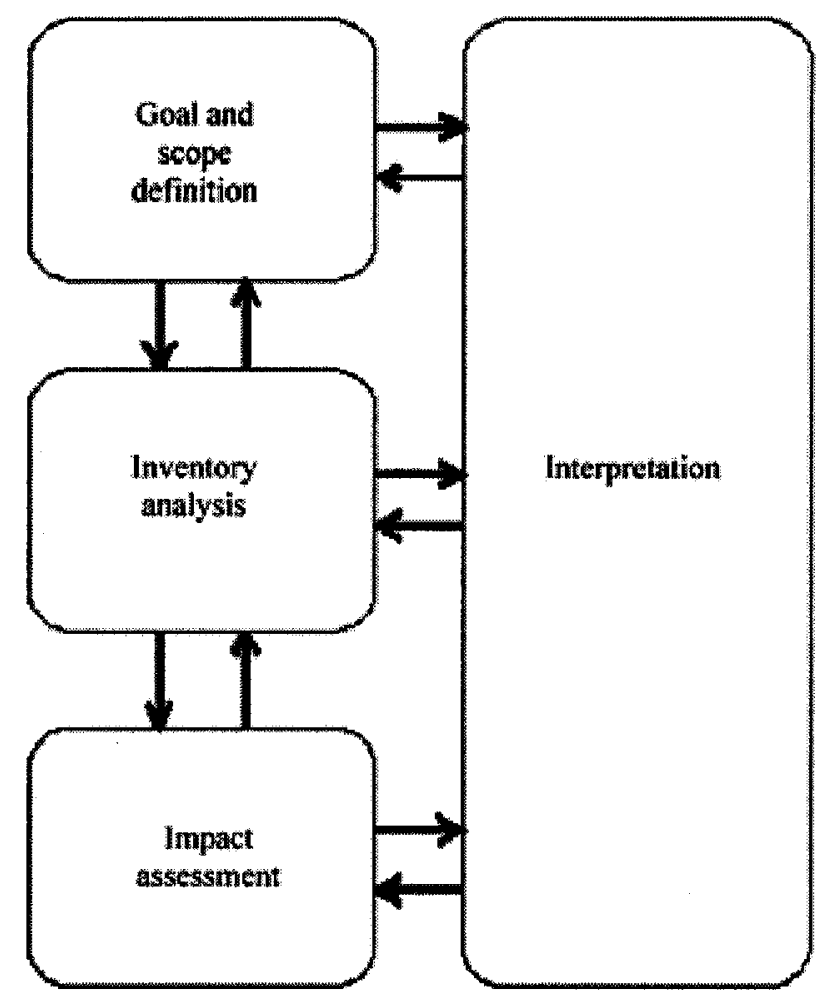

Figure 5.2 - Phases of an LCA from ISO 2006a, pg. 8

The checklist table arrangement provides a basis to assess the LCA conducted here against the "state of the art". Recall one of the challenges facing the application of LCA to biofuel identified in section 3.2 was the lack of shared rules for LCA design. In closely following ISO 14044, this research provides a reasonable basis for assessing the feasibility of implementing biofuel LCA according to the ISO standardized approach (related to research objective \#2).

This section provides the reader a clear and transparent summary of the choices made when designing this LCA. Duplication of material from other sections is minimized through the summary tables which reference information throughout the thesis. The text following the tables is reserved for concepts that require more discussion. 


\subsection{Scope and Goal Definition}

Table 5.1 : Requirements for "scope and goal definition" phase (adapted from ISO $14044,2006 \mathrm{~b}$ ) and correspondence of this LCA

\begin{tabular}{|c|c|}
\hline ISO 14044 Requirement & This LCA \\
\hline Goal and scope definition & 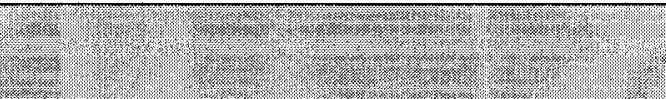 \\
\hline $\begin{array}{l}\text { Goal defined with intended application of study, } \\
\text { intended audience, and whether or not intended } \\
\text { to be used in comparative assertions disclosed to } \\
\text { the public }\end{array}$ & $\begin{array}{l}\text { Goal statement: } \\
\text { The goal of this LCA is to describe the } \\
\text { life cycle fossil fuel requirements and } \\
\text { greenhouse gas emissions for } \\
\text { production of E5 and gasoline in } \\
\text { Ontario and to explore the extent to } \\
\text { which these requirements vary } \\
\text { regionally } \\
\text { LCA is comparative and intended } \\
\text { mainly for meeting academic } \\
\text { requirements. }\end{array}$ \\
\hline Scope defined with particular consideration of: & -- \\
\hline $\begin{array}{l}\text { Function (performance characteristics of system } \\
\text { being studied) and functional unit defined }\end{array}$ & $\begin{array}{l}\text { A } 45 \mathrm{~km} \text { car trip travelled in a light } \\
\text { duty vehicle } \\
\text { See } 5.1 .1 \text { - functional unit discussion }\end{array}$ \\
\hline $\begin{array}{l}\text { System boundary established and criteria for } \\
\text { establishment identified and explained. } \\
\text { Decisions to omit life cycle stages must be } \\
\text { clearly stated and reasons and implications } \\
\text { explained }\end{array}$ & $\begin{array}{l}\text { Boundary of E5 introduced in figure } \\
\text { 2.1. Life-cycle stage added see } 5.1 .2- \\
\text { boundary discussion }\end{array}$ \\
\hline $\begin{array}{l}\text { Process flow diagram helpful to showing unit } \\
\text { processes and such that only inputs at boundary } \\
\text { are elementary flows and product flows }\end{array}$ & $\begin{array}{l}\text { Flow diagrams for stage \#1 farming } \\
\text { corn and stage \#2 manufacturing } \\
\text { ethanol in appendix figure b. } 1 \text { and b. } 2 \\
\text { No flow diagrams for background } \\
\text { processes }\end{array}$ \\
\hline
\end{tabular}


Table 5.1 (continued)

Requirements for "scope and goal definition" phase and correspondence of this LCA

\begin{tabular}{|c|c|}
\hline ISO 14044 Requirement & This LCA \\
\hline $\begin{array}{l}\text { Cut-off criteria for inclusion of inputs and } \\
\text { outputs described and effects of cut-off } \\
\text { assessed }\end{array}$ & $\begin{array}{l}\text { Criteria used were : boundaries of } \\
\text { previous studies, comparability of E5 } \\
\text { vs. gasoline boundaries, and anticipated } \\
\text { significance of inputs } \\
\text { See } 5.1 .2 \text { - boundary discussion and } \\
5.1 .3 \text { background process boundary } \\
\text { discussion }\end{array}$ \\
\hline $\begin{array}{l}\text { Determine which impact categories are } \\
\text { included in study }\end{array}$ & Fossil fuel and GHG \\
\hline $\begin{array}{l}\text { Data quality requirements specified and should } \\
\text { address age of data, length of time over which } \\
\text { data should be collected, geographical } \\
\text { coverage, technology coverage, precision, } \\
\text { completeness, representativeness, consistency, } \\
\text { reproducibility sources, uncertainty }\end{array}$ & $\begin{array}{l}\text { Recent data using multi-point averages } \\
\text { required. Data should be from study } \\
\text { regions. Representativeness need not be } \\
\text { statistical. } \\
\text { See discussion of data quality in } 5.1 .4\end{array}$ \\
\hline $\begin{array}{l}\text { Treatment of missing data is documented and } \\
\text { data from specific sites or representative } \\
\text { averages should be used for unit processes that } \\
\text { contribute majority of mass and energy flows }\end{array}$ & See above and 5.1.4 \\
\hline $\begin{array}{l}\text { If a comparative study the equivalence of } \\
\text { systems is evaluated for same functional unit, } \\
\text { system boundary, data quality, allocation } \\
\text { procedures, decision rules on inputs and } \\
\text { outputs - and if disclosed to public should be } \\
\text { subject to critical review }\end{array}$ & $\begin{array}{l}\text { Similarity between E5 and gasoline } \\
\text { product systems in functional unit } \\
\text { evaluated in } 5.1 .1 \text { and system boundary } \\
\text { in 5.1.3. Potential differences in data } \\
\text { quality and boundary conditions } \\
\text { discussed in 5.1.3 and 5.1.4. } \\
\text { Same allocation (5.2) rules used. } \\
\text { Critical review occurs during thesis } \\
\text { evaluation. }\end{array}$ \\
\hline
\end{tabular}




\subsection{1...Functional Unit discussion}

The function of both E5 and conventional gasoline is to provide fuel for automobiles. The fuel is burned within an internal combustion engine to transform chemical energy into mechanical energy to propel the vehicle. Since the end use of both fuels is a car trip, a functional unit based on a suitable average car trip was chosen. Using Statistics Canada (2007b) survey data for Canadian light duty vehicle use in 2007 a trip distance of $45 \mathrm{~km}$ was selected. All $\mathrm{CO}_{2}$ equivalent emissions and fossil energy inputs will be expressed relative to those emitted by a light vehicle with average fuel efficiency of $10.91 / 100 \mathrm{~km}$ reported in the same survey.

The functional unit is thus:

\section{A $45 \mathrm{~km}$ car trip travelled in a light duty vehicle}

E5 fuel and gasoline both provide the function of moving a light duty vehicle through combustion of fuel in an internal combustion energy. However, the available energy content of each fuel is different. The energy density of E5 fuel is less than that of gasoline. This means that (in current gasoline engine designs) more E5 fuel than conventional gasoline is required to provide the functional unit. This is accounted for in the LCA by different fuel economy values: E5 fuel is considered to have an available energy content of $34.13 \mathrm{MJ} / \mathrm{l}$ and thus a proportionally reduced fuel efficiency of 11.1 litres $/ 100 \mathrm{~km}$, while gasoline has the fuel efficiency of $10.91 / 100 \mathrm{~km}$ reported in Stat Can (2007b). 
Kim and Dale (2006) suggest that the choice of functional unit for ethanol blends can sway the results. They found that in a comparison of the environmental impacts of E10 and E85 fuels, decisions regarding the designation of functional unit was critical as a functional unit of $\mathrm{km}$ travelled per $\mathrm{kg}$ of ethanol, favoured $\mathrm{E} 10$, whereas a functional unit of grams of ethanol required per km travelled favoured E85 fuels. The entire reason for this difference appears to rest on their assumption that E-10 has the same fuel economy as conventional gasoline, while the fuel economy of E-85 is reduced compared to conventional gas. Kim and Dale (2006) appear to overlook that the functional units they compare are two sides of the same coin, except that one uses a longer distance. As the chosen distance increases, the assumption of no reduction in fuel economy for E-10 is magnified and the appearance of ethanol providing more function with the same product logically reduces the environmental benefits compared to the fuel economy reduced E-85 product. Fuel economy assumptions are therefore particularly important to functional units with long travel distances (such as the $45 \mathrm{~km}$ trip used in this thesis) and underlines the need to adjust fuel economy to account for slightly lower energy density of the E5 blend.

\subsubsection{Boundary discussion}

The generic boundary is found in figure 2.1. Note that the "use of fuel in vehicle" stage was initially placed outside the boundary but as the LCA progressed it became clear that the combustion of gasoline is the major source of GHG and fossil energy use for gasoline use and was needed to accurately compare the products. For ethanol combustion, fuel combustion is considered GHG neutral and this was the initial reason for placing outside the boundary. It is common for LCA-type evaluations of biofuel to stop the boundary at 
sale of the product, von Blottnitz and Curran's (2007) review recommends extending the boundary to use of the fuel product in engines.

Once the general boundary is established flow diagrams are constructed (Appendix B) and a list of the individual activities / unit processes created. To help gauge which activities are significant enough to include in the inventory, five of the most relevant studies were reviewed (Farrell et al , 2006, GHGenius , 2007, Groode and Heywood, 2007, Levelton et al, 2000, Searchinger et al, 2008).

One striking feature of all of the studies reviewed is the lack of detail on the production activities covered in the assessments. For example, all studies included fuel used to run farm machinery, but in none was the fuel use linked to particular activities such as seeding versus harvesting. In other words, the "unit process" level of information was not developed. Surveillance type survey information or industry wide estimates appear to have been used in all assessments. The lack of attention shown to the procedure for setting LCA boundaries reinforces the first challenge for advancing biofuel LCA introduced in chapter three - that of a lack of a shared rules. Nonetheless the list of generic survey level activities modelled in each of these five studies still provide an indication of any elements that may be missing from the flow diagrams developed earlier.

New elements not originally considered but part of the literature to consider for stage \#1 are

- Farm labour, 
- Production of packaging for inputs and,

- Land use change.

One new element for stage \#2 is

- Transporting water to the ethanol plant.

The new elements of farm labour and pumping water in ethanol plant were included in the inventory. Note that Farrell et al (2006) attribute the farm labour value to outsourcing of grain drying - a unit process which is accounted for separately in this LCA.

The production of packaging for inputs activity was excluded as the entire value (found in Graboski (2002) and reproduced by Farell et al. (2006)) is due to the format of the data source that Graboski used and represents the energy required to formulate ammonia into different types of nitrogen fertilizers. In most other studies (including this LCA), the reformulating of $\mathrm{N}$ fertilizer is aggregated into the total fertilizer production value and thus the "packaging inputs" activity is already accounted for.

The production of "capital" machinery used in corn farming and ethanol production was excluded for a different reason. To ensure legitimacy of comparisons between products, only corresponding elements included in the gasoline system should be part of the E5 system. The boundary for the gasoline production (table 5.2) extends only to direct inputs to the process and not to the production of infrastructure equipment. Therefore the 
activities of producing farm machinery and producing ethanol plant equipment are also excluded.

The question of whether or not to include land use changes depends on assumptions of new land being brought under cultivation to grow corn for ethanol. Using Stats Can data from 2005-2008 (table 3.2), an increase in corn area in Ontario was seen followed by a decrease in 2008. For the purposes of this study this evidence is interpreted to mean that the biofuel demand which has risen constantly since 2005 is not forcing new area under corn production and land use changes are excluded from this study. This is most likely to remain true for the near to medium term (i.e., next five years) especially if ethanol blends remain typically E5 fuels. Penetration of E85 fuels into the marketplace would require a re-evaluation of this assumption.

To gauge the impact of these exclusions, the expected relative $\%$ contribution of each new element to the total for stage $\# 1$ and stage $\# 2$ was derived using data from Farell et al (2006). The production of input packaging makes up a small portion of the total fossil energy (less than $0.5 \%$ ) and the production of capital equipment accounts for less than $2.5 \%$. Thus even if the logic of excluding these elements can be argued, the final impact on overall results is expected to be relatively minor.

Finally, during data collection it became clear that some additional activities were not included in boundary set by other analysts or conceived in the flow diagrams. Two activities from the ethanol manufacturing stage were added, first use of antibiotics to 
fermentation tanks and secondly, cleaning the tanks. The full list of activities can be found in the inventory sheets in Appendix E.

\subsubsection{Background stages boundary discussion}

Because of the complexity and amount of data required to describe the E5 production chain, an important practical decision was made to focus the research on the ethanol production stages. These will be termed the "foreground" processes, for which primary data will be collected. The background part of the production chain will rely on secondary sources. This distinction is a common practical choice during life-cycle assessments (Curran, 2007, Guinnee 2004). Note that Figure 2.1, which sets the foundation for the LCA, distinguishes foreground stages (within heavier lined box) and background stages (within larger box) processes. The boundary and scope of activities included in the E5 background life cycle stages must be considered separately from the foreground stages in this LCA. The data in this part of the LCA are all from secondary sources (largely the GHGenius database - more details on sources section 5.3.6), and the boundary used in the secondary source is duplicated in this LCA.

Table 5.2 provides an indication of the scope of activities included in each of the background processes. Where the original source was unclear, details were supplemented by consultation with the report authors (O'Connor, 2008). The boundary for these parts of the E5 life cycle is less precise than for the foreground processes but is consistent. For example, the exploration activities required to identify oil reservoirs: exploratory drilling, retrieving core samples to evaluate and logging the electical, acoustic and radioactive properties of rocks (Shell, 1983), are outside the boundary of 
this life cycle assessment. This is consistent with the analogous activities in corn production (e.g., activities to identifying and clear the land are not included).

Table 5.2:Boundary for background life cycle stages of E5 production

\begin{tabular}{|l|l|l|}
\hline Stage & Included & Excluded \\
\hline Crude oil extraction & $\begin{array}{l}\text { Drilling and recovery } \\
\text { Gas leaks and flares } \\
\text { Transportation }\end{array}$ & $\begin{array}{l}\text { Building rigs and other } \\
\text { infrastructure } \\
\text { Exploration activities }\end{array}$ \\
\hline Oil refining & $\begin{array}{l}\text { Eight process areas } \\
\text { (distillation, blowdown, } 3 \\
\text { forms of cracking, } \\
\text { separation, cooling, } \\
\text { valves/drains) } \\
\text { Transportation }\end{array}$ & Producing infrastructure \\
\hline Blending & $\begin{array}{l}\text { Fuels used, electricity, } \\
\text { natural gas and fuel oil for } \\
\text { blending, heating, lights } \\
\text { Transportation }\end{array}$ & Producing infrastructure \\
\hline Sale at gas station & $\begin{array}{l}\text { Pumping gas } \\
\text { Transportation }\end{array}$ & $\begin{array}{l}\text { Heating and maintaining } \\
\text { buildings } \\
\text { Producing infrastructure }\end{array}$ \\
\hline Use and disposal in vehicle & $\begin{array}{l}\text { Combustion of fuel in } \\
\text { engine, incl. } \mathrm{CH}_{4} \text { and } \mathrm{N}_{2} \mathrm{O}\end{array}$ & $\begin{array}{l}\text { End of life of vehicle } \\
\text { Vehicle maintenance } \\
\text { emissions (e.g., engine oil } \\
\text { emissions excluded) }\end{array}$ \\
\hline
\end{tabular}

\subsubsection{Data requirements discussion}

E5 fuel in Ontario is a relatively new product and technology for producing the components is rapidly changing. Therefore, this LCA should rely on the most up to date data. For the ethanol manufacturing plant, daily estimates are used which were averages of production over the life of the plant from 2007 to 2008. Corn farming data is a three year average of years 2005-2007. In the case of the background life cycle stages, the age 
of the data available is more variable and ranges from 2003 for syncrude crude oil recover (stage 3 - crude oil recovery - for S.Ont case) to up to 20 years in the case of gas station energy use and emissions (stage 6 - retail - for all cases).

The geographical coverage of the data is a core focus of this study and the data collected should be from the S.Ont and E.Ont case studies developed here. For the foreground life cycle stages this is accomplished through direct sampling from the region. However, the background life cycle stages rely on a mix of national and sub-national information. In some cases this information is relatively closely linked to the case study characteristics (e.g., automobile fuel economy use figures for the Ontario regions are derived from Canadian estimates). In other cases the geographic coverage is less specific (e.g., North Sea offshore oil extraction data for E.Ont case relies on US oil and gas sector-wide survey information).

The difference in temporal and geographical quality of data between the foreground life cycle stages and the background stages of this LCA is recognized and is part of the second challenge of conducting biofuel LCA identified in section 3.2, that of spatial and temporal representation. The entire chain of production for E5 involves disparate activities from varied industries and locations. Direct data collection for all stage would cross continents and is highly impractical.

Again, the implication of these differences is that during interpretation of results more emphasis should be placed on drawing conclusions from the foreground stages where 
data quality and reach are more certain. However, legitimate comparisons can still be made in the other life cycle stages since internally consistent data is used (i.e, same quality, same boundaries).

It is also important to note that statistically represention is not claimed in any of the production systems examined. The case examples were chosen because they are divergent. Attempts were made to select an example with the typical characteristics of the region. A consistent data collection method was applied during the inventory stage to improve reproducibility of the data and results. The next section describes in more detail the collection of data in the life cycle inventory analysis. 


\subsection{Inventory Analysis}

Table 5.3: Requirements for "inventory analysis" phase (adapted from ISO 14044, 2006b) and correspondence of this LCA

\begin{tabular}{|l|l|}
\hline ISO 14044 Requirement & \\
\hline Life cycle inventory analysis & This LCA \\
\hline All operational steps below performed? & Yes \\
\hline $\begin{array}{l}\text { Data is collected for each unit process (unit } \\
\text { process = smallest element considered in the } \\
\text { life cycle inventory analysis for which input } \\
\text { and output data are quantified) and sources } \\
\text { are referenced with comment on data quality }\end{array}$ & $\begin{array}{l}\text { Yes for stage 1. Partially for stages 2 and } \\
\text { collected for each unit process. }\end{array}$ \\
$\begin{array}{l}\text { See data inventory discussion 5.2.1 and } \\
\text { summary table 5.6 }\end{array}$ \\
\hline $\begin{array}{l}\text { Consistent modelling of product system } \\
\text { through measures such as flow diagrams, } \\
\text { description of each unit process, list that } \\
\text { specifies units used and other measures }\end{array}$ & $\begin{array}{l}\text { Flow diagrams in Appendix B. List of } \\
\text { unit process / activities in Appendix E }\end{array}$ \\
\hline $\begin{array}{l}\text { Data may be classified as 1) energy inputs, } \\
\text { raw material inputs, ancillary inputs 2) } \\
\text { products, co-products and waste 3) releases to } \\
\text { air, water and soil4) other environmental } \\
\text { aspects }\end{array}$ & $\begin{array}{l}\text { Yes. See data collection sheet in } \\
\text { Appendix D }\end{array}$ \\
\hline $\begin{array}{l}\text { Calculation procedures shall be documented } \\
\text { and consistent (ISO 14044 gives example of } \\
\text { consistent use of higher or of lower heating } \\
\text { value) }\end{array}$ & Yes. See section 5.3.1 for discussion \\
\hline $\begin{array}{l}\text { Validation of data through for example } \\
\text { checks on mass and energy balances for each } \\
\text { unit process }\end{array}$ & $\begin{array}{l}\text { Good external validity of collected data } \\
\text { through comparison to Gen.Ont values. } \\
\text { For example, the quantity of natural gas } \\
\text { collected for ethanol plant makes sense } \\
\text { compared to that reported in trade } \\
\text { literature and used in Gen.Ont case (see } \\
\text { appendix E) }\end{array}$ \\
\hline $\begin{array}{l}\text { and } \\
\text { and }\end{array}$ & \\
\hline
\end{tabular}




\section{Table 5.3 (continued)}

\section{Requirements for "inventory analysis" phase and correspondence of this LCA}

\begin{tabular}{|l|l|}
\hline ISO 14044 Requirement & \multicolumn{1}{|c|}{ This LCA } \\
\hline $\begin{array}{l}\text { All system input and output data should be } \\
\text { referenced to functional unit and the level of } \\
\text { aggregation of data should be consistent with } \\
\text { goals of the study }\end{array}$ & $\begin{array}{l}\text { Appendix D provides copies of the data } \\
\text { collection tables referenced to a litre of } \\
\text { fuel. All results (see section six) are } \\
\text { reported by functional unit. }\end{array}$ \\
\hline $\begin{array}{l}\text { System boundary is refined based on } \\
\text { sensitivity analyses and cut-off criteria } \\
\text { established earlier }\end{array}$ & $\begin{array}{l}\text { This was done earlier in the scoping } \\
\text { section, see section 5.1 }\end{array}$ \\
\hline $\begin{array}{l}\text { Allocation procedure to allocate inputs and } \\
\text { outputs over different products is documented } \\
\text { and sensitivity analyses conducted if multiple } \\
\text { approaches possible }\end{array}$ & $\begin{array}{l}\text { Yes. Documented in 5.2.2 Sensitivity to } \\
\text { multiple approaches checked in 5.4 }\end{array}$ \\
\hline $\begin{array}{l}\text { Allocation should be avoided by dividing unit } \\
\text { processes into multiple processes or } \\
\text { expanding the product system or if cannot be } \\
\text { avoided then allocation based on physical } \\
\text { relationships or lastly by economic } \\
\text { relationship }\end{array}$ & $\begin{array}{l}\text { Three points of allocation. Two through } \\
\text { expanding the product system, one a kind } \\
\text { of mass / volume allocation. See section } \\
5.2 .2 \text { allocation discussion }\end{array}$ \\
\hline $\begin{array}{l}\text { Allocation in reuse and recycling procedures } \\
\text { stated and if allocation needed based on mass, } \\
\text { secondly economic value and lastly number } \\
\text { of times used }\end{array}$ & N/A \\
\hline
\end{tabular}

\subsubsection{Data inventory discusssion}

The data required for this LCA are emissions of the gases $\mathrm{CO}_{2}, \mathrm{CH}_{4}$ and $\mathrm{N}_{2} \mathrm{O}$ to assess total greenhouse gas emissions reported in equivalent $\mathrm{CO}_{2}$ units $\left(\mathrm{CO}_{2} \mathrm{eq}\right)$ and quantities of fossil fuels. This work follows the practice of other biofuel LCA studies and estimates $\mathrm{CO}_{2}$ eq quantities using emission factors rather than direct measurement. To assess fossil fuel use, volumes of direct fossil energy inputs (e.g., coal, natural gas, gasoline, diesel, 
propane) and secondary fossil energy inputs (e.g., electricity derived from fossil fuel) were collected.

For the foreground processes two different inventory tables were developed for each of three $\mathrm{E} 5$ cases (Appendices D and E). The corn production collection table identifies 32 separate processes with 72 types of inputs and outputs to collect. The data sheet for ethanol manufacturing stage originally identified 16 processes and 43 inputs for detailed collection, however the ethanol plants in the study site were only willing to provide overall quantities of 14 inputs and outputs without attributing to the individual process steps in the manufacturing plant.

For the background processes, the global scale of the oil industry, confidential nature of the business and research time and resource constraints led to the need to rely on secondary sources, most notably the GHGenius database. A summary of sources by life cycle stages is shown in table 5.4 below. Additional references can be found in the inventory sheets in Appendices D to H. 
Table 5.4 - Origin of inventory data for products considered in this LCA

\begin{tabular}{|c|c|c|c|c|c|c|c|}
\hline Caselstage & Farm corn & $\begin{array}{l}\text { Manufacture } \\
\text { ethanol }\end{array}$ & Extract oil & $\begin{array}{l}\text { Manufacture } \\
\text { gasoline }\end{array}$ & $\begin{array}{l}\text { Blend and } \\
\text { store }\end{array}$ & $\begin{array}{l}\text { Distribution } \\
\text { and Sale }\end{array}$ & Use \\
\hline S.Ont E5 & $\begin{array}{l}\text { Direct from } \\
\text { corn farmer in } \\
\text { Lambton }\end{array}$ & $\begin{array}{l}\text { Direct from } \\
\text { proxy ethanol } \\
\text { plant, distances } \\
\text { adjusted }\end{array}$ & \multirow[t]{2}{*}{$\begin{array}{l}\text { Modelled } \\
\text { output for } \\
\text { syncrude } \\
\text { from } \\
\text { GHGenius }\end{array}$} & \multirow{2}{*}{$\begin{array}{l}\text { Modelled } \\
\text { output for } \\
\text { S.Ont } \\
\text { refineries from } \\
\text { GHGenius }\end{array}$} & $\begin{array}{l}\text { Census survey } \\
\text { data, adjusted } \\
\text { for S.Ont } \\
\text { distances }\end{array}$ & \multirow[t]{6}{*}{$\begin{array}{l}\text { Census survey } \\
\text { data for } \\
\text { gasoline } \\
\text { stations }\end{array}$} & \multirow{6}{*}{$\begin{array}{l}\text { National } \\
\text { survey data } \\
\text { and emissions } \\
\text { model } \\
\text { adjusted for } \\
\text { fuel economy } \\
\text { loss in e- } \\
\text { blends }\end{array}$} \\
\hline $\begin{array}{l}\text { S. Ont } \\
\text { gasoline }\end{array}$ & -- & -- & & & $\begin{array}{l}\text { Same without } \\
\text { ethanol portion }\end{array}$ & & \\
\hline E.Ont E5 & $\begin{array}{l}\text { Direct from } \\
\text { corn farmer in } \\
\text { Ottawa }\end{array}$ & $\begin{array}{l}\text { Direct from } \\
\text { proxy ethanol } \\
\text { plant, distances } \\
\text { adjusted }\end{array}$ & \multirow[t]{2}{*}{$\begin{array}{l}\text { Modelled } \\
\text { output for } \\
\text { offshore oil } \\
\text { from } \\
\text { GHGenius }\end{array}$} & \multirow{2}{*}{$\begin{array}{l}\text { Modelled } \\
\text { output for } \\
\text { eastern Canada } \\
\text { refineries from } \\
\text { GHGenius }\end{array}$} & $\begin{array}{l}\text { Census survey } \\
\text { data, adjusted } \\
\text { for E.Ont } \\
\text { distances }\end{array}$ & & \\
\hline $\begin{array}{l}\text { E.Ont. } \\
\text { gasoline }\end{array}$ & -- & -- & & & $\begin{array}{l}\text { Same without } \\
\text { ethanol portion }\end{array}$ & & \\
\hline Gen.Ont E5 & $\begin{array}{l}\text { Province wide } \\
\text { reports and ag. } \\
\text { extension } \\
\text { information }\end{array}$ & $\begin{array}{l}\text { Trade literature } \\
\text { and other } \\
\text { secondary } \\
\text { sources }\end{array}$ & \multirow{2}{*}{$\begin{array}{l}\text { Modelled } \\
\text { output for } \\
\text { default Ont } \\
\text { mix in } \\
\text { GHGenius }\end{array}$} & \multirow{2}{*}{$\begin{array}{l}\text { Modelled } \\
\text { output for } \\
\text { Ontario } \\
\text { refineries from } \\
\text { GHGenius }\end{array}$} & $\begin{array}{l}\text { Census survey } \\
\text { data, adjusted } \\
\text { for Gen.Ont } \\
\text { distances }\end{array}$ & & \\
\hline $\begin{array}{l}\text { Gen.Ont } \\
\text { gasoline }\end{array}$ & -- & -- & & & $\begin{array}{l}\text { Same without } \\
\text { ethanol portion }\end{array}$ & & \\
\hline
\end{tabular}


The types of data collected varied depending on the type of activity being inventoried. For example, planting corn required the producer to provide seeding rate, estimate of diesel fuel used to pull the planter, type of tractor pulling the planter, type of planter, any insecticide or fungicide treatment to the seed, distance from place of seed sale to farm, and details on transportion type. On the other hand, data for the production of syncrude and other crude oil types required adjustments to the GHGenius model in order to extract output values.

It was optimistic to expect corn and ethanol producers to have and to share records and estimates of inputs for each and every production activity. To minimize this difficulty a number of strategies were used: 1) copies of the data collection table were sent to producers beforehand to help prepare, 2) expected values based on best practice data were available during the interviews to compare to reported estimates provided by the farmers or ethanol plant managers, and 3) reporting in different metrics was used (for example, when fuel use for the cultivating activity was not known, an estimate of number of hours before filling the tank was collected and later converted to fuel use with reported fuel efficiency for the equipment).

It was not possible to collect unit process level data for the ethanol plant. Instead daily estimates of all of the material and energy inputs into the process were collected. This means that the analysis of the energy and GHG profile of the ethanol production plant is limited to overall process data and not data from each individual process (e.g., the natural 
gas used in ethanol distillation towers is not separated from natural gas used to dry the distillers grain with soluables).

\subsubsection{Allocation discussion}

Choosing how to partition or allocate the environmental burden between multiple products produced in the same process is one of the most difficult parts of conducting LCA. The choice of allocation procedure significantly changes and can even determine the results of LCA (Weidema, 2002, Curran 2007). In the E5 production system, there are three points where multiple products are produced which need to be factored out of the LCA.

a) The protein and fat portion of corn that is not converted to ethanol is turned into a livestock feed supplement known as dried distillers grain with soluables (DDGS)

b) $\mathrm{CO}_{2}$ is captured during fermentation of corn starch to ethanol and compressed for use in the food and beverage industry

c) Diesel, fuel oil and other distillates are produced from the same crude oil as is used to produce gasoline

The simplest way to allocate a portion of the environmental burden to co-product is to determine the mass of the product and attribute based on respective weight. For example, the daily yields at the ethanol plant are 350,000 litres of ethanol, 300,000 kgs of DDGS and $300,000 \mathrm{~kg}$ of $\mathrm{CO}_{2}$ for an approximate total of $950,000 \mathrm{~kg}$. The total electricity used to make all three products is $65000 \mathrm{KWHr}$ and following the mass allocation approach 
the amount of electricity attributed solely to ethanol would be the ratio of ethanol produced to total weight of products produced $\left(350,000 / 950,000^{7}\right)$ multiplied by 65,000 KWHr. From this example it is apparent that mass allocation can dramatically reduce the environmental burden to one third of what it would have been if no allocation was done. Kim and Dale (2002) found that using mass allocation to deal with the DDGS co-product reduce the burden attributed to ethanol more than any other method.

The second way to allocate is to use the price of the product to provide the allocation ratio. So if ethanol sells for $\$ 1$ per litre and DDGS for $\$ 0.1$ and $\mathrm{CO}_{2}$ for $\$ 0.1$ then the ratio (\$1/1.2\$) is used to partition burden to ethanol. Allocating based on economic value is the least preferred allocation approach in ISO 14044.

The third allocation method is the displacement approach or system expansion approach and is the preferred method under ISO 14044. The objective is to expand the LCA to include an assessment of the alternative production method for producing the co-product, and then subtract this value from that of the product system of interest. For example, commercially produced $\mathrm{CO}_{2}$ is most often derived in during the production of ammonia. Since $\mathrm{CO}_{2}$ from the ethanol production process displaces this type of $\mathrm{CO}_{2}$, the fossil fuel required to produce the $\mathrm{CO}_{2}$ in the ammonia process can be subtracted from the total fossil fuel value for the ethanol production system. This serves to remove the burden attributable to production of the $\mathrm{CO}_{2}$ commodity and isolates the burden attributable to ethanol.

\footnotetext{
${ }^{7}$ Assumes density of $1 \mathrm{~kg} / 1$ litre of ethanol, good enough estimate to illustrate how mass allocation is performed.
} 
The system expansion / displacment approach was followed for DDGS and liquid $\mathrm{CO}_{2}$ while a type of mass allocation was used in the diesel and other distillates calculation.

DDGS: For the ethanol plants found in the case studies, the DDGS feed supplement is sold to the beef cattle industry. DDGS is added to a corn, silage, and soyabean meal or urea mix and replaces grain corn and urea or soyabean. OMAFRA (2008) suggests $20 \%$ DDGS is the optimum amount in feed diet and at this rate feeding trials have shown that $1 \mathrm{~kg}$ of DDGS replaces $0.94 \mathrm{~kg}$ of grain corn and $0.06 \mathrm{~kg}$ of urea (Trenkle, 2003). For simplicity and since the amount of urea replaced is low, only the fossil fuel and GHG attributed to $0.94 \mathrm{~kg}$ of grain corn $/ \mathrm{kg}$ of DDGS is subtracted from the E5 product for this LCA.

It is worth noting that Pimental and Patzek (2005) have argued that the premise of the allocation is false as no one would bother removing starch from corn only to obtain high protein animal food. This perspective is interesting and has led various analysts to decide against portioning some of the energy and GHG burden to DDGS to remain conservative (e.g..Dias de Oliveira, (2005), Hoode and Greywood (2007)). However this choice fails to consider the replacement of products that occurs when DDGS is used. In other words, while it is true no one would farm corn to produce DDGS, it is also true that no one has to farm the corn and soybean that DDGS replaces. 
$\mathrm{CO}_{2}$ for food and beverage: The ethanol plants in the case studies capture (or will capture) $\mathrm{CO}_{2}$ released during fermentation of sugar to alcohol. This $\mathrm{CO}_{2}$ is commercially used to carbonate beverages and store food and is transported through a pipe to a pressurized container close to the plant.

Commercially produced $\mathrm{CO}_{2}$ is most commonly captured as an inevitable by-product during ammonia production and requires a capture and reforming step. The fossil fuel and GHG consumed to complete these steps has been calculated using ammonia production data from (Worrell et al, 2000) and removed from the E5 product.

The fact that commercially produced $\mathrm{CO}_{2}$ is a greenhouse gas raises some interesting scenarios that push the edges of thinking about carbon neutral processes and allocation. The $\mathrm{CO}_{2}$ in the ethanol plant is derived from carbon from corn and thus release to the atmosphere (occurs in many ethanol plants where $\mathrm{CO}_{2}$ from fermentation tank is vented) is considered greenhouse gas neutral. If the gas was captured and permanently sequestered, then it could be seen as a greenhouse gas negative activity (i.e., removing normally cycling carbon from atmosphere). However, since food and beverage $\mathrm{CO}_{2}$ is released when the food product is consumed, there is no permanent sequestration. The commercial $\mathrm{CO}_{2}$ produced during the making of ammonia on the other hand, is derived from a fossil fuel (natural gas) and thus contributes to higher concentrations of greenhouse gas in the atmosphere. If the $\mathrm{CO}_{2}$ produced during ethanol production were to prevent the production of $\mathrm{CO}_{2}$ in the ammonia process then another point of greenhouse gas removal is plausible. However, the chemical process to generate ammonia $\left(\mathrm{NH}_{4}\right)$ 
currently relies on natural gas (principally $\mathrm{CH}_{4}$ ) as a hydrogen supplier which inevitably leads to excess $\mathrm{CO}_{2}$ production. Thus even if $\mathrm{CO}_{2}$ from ethanol production displaces that of ammonia production, it is only the $\mathrm{CO}_{2}$ and other greenhouse gases arising from $\mathrm{CO}_{2}$ capture steps that can be allocated away from the ethanol process, not the $\mathrm{CO}_{2}$ itself (since this would still be created and vented in any case). ${ }^{8}$

The federal government's GHGenius model calculates carbon captured for industrial use at ethanol plant as a sequestration activity (GHGenius, 2006). This approach presumes permanent sequestration of $\mathrm{CO}_{2}$ and is erroneous for the reasons discussed above.

Diesel and other distillates: The data for this background stage is taken directly from the GHGenius model which downwardly adjusts literature estimates of energy consumed for gasoline refining by applying a ratio derived from allocation of total refining energy to proportion of gasoline produced compared to other products.

\footnotetext{
${ }^{8}$ One might argue that in the DDGS case the opposite presumption is taken, i.e., that an allocation credit is given to ethanol when farming corn and soybeans would occur anyway, but what distinguishes the two is that the displaced $\mathrm{CO} 2$ production process is a by-product of another process (ammonia production) that occurs irrespective of satiated need for $\mathrm{CO} 2$ from the biofuel process
} 


\subsection{Impact Assessment}

Table 5.5: Requirements for "impact assessment" phase (adapted from ISO 14044, 2006b) and correspondence of this LCA

\begin{tabular}{|c|c|}
\hline ISO 14044 Requirement & This LCA \\
\hline \multicolumn{2}{|l|}{ Life cycle impact assessment } \\
\hline $\begin{array}{l}\text { Impact categories shall be selected with } \\
\text { category indicators and characterisation } \\
\text { models. LCI results assigned to each impact } \\
\text { category and calculation of category indicator } \\
\text { is done. Detailed requirements below; }\end{array}$ & $\begin{array}{l}\text { Impact categories = climate change } \\
\text { and (fossil fuel) resource use } \\
\text { Category indicators }=\mathrm{kg} \mathrm{CO}_{2} \mathrm{eq} \text { and } \\
\text { MJ per functional unit } \\
\text { Characterization model = radiative } \\
\text { forcing in atmosphere for } \mathrm{CO}_{2} \text { eq and } \\
\text { joule energy unit for fossil fuel }\end{array}$ \\
\hline $\begin{array}{l}\text { Selection of impact categories reflect } \\
\text { comprehensive set of environmental issues } \\
\text { (taking the goal and scope into consideration) }\end{array}$ & $\begin{array}{l}\text { Not a comprehensive list of categories } \\
\text { but does meet goal and scope. }\end{array}$ \\
\hline $\begin{array}{l}\text { Description of how inventory results are linked } \\
\text { to category indicator ("environmental } \\
\text { mechanism", "characterization model") }\end{array}$ & See first requirement in this table \\
\hline $\begin{array}{l}\text { Non mass and energy flow inventory data (e.g. } \\
\text { land use) is identified and relationship to } \\
\text { corresponding category indicators described }\end{array}$ & N/A - not part of inventory data \\
\hline $\begin{array}{l}\text { Each impact category should include category } \\
\text { endpoint, the LCI results that can be assigned } \\
\text { to endpoint and identification of } \\
\text { "characterization model" }\end{array}$ & $\begin{array}{l}\text { Endpoints of climate change are global } \\
\text { systems, endpoint of resource use is } \\
\text { scarcity, } \mathrm{CO}_{2} \text { eq measure is a } \\
\text { characterization model for radiative } \\
\text { forcing in atmosphere, } \mathrm{MJ} \text { measure is } \\
\text { a model for energy use }\end{array}$ \\
\hline $\begin{array}{l}\text { Impact categories, category indicator and } \\
\text { characterization model should be; } \\
\text { internationally accepted..., characterization } \\
\text { model should be scientifically valid and } \\
\text { empirically based. }\end{array}$ & $\begin{array}{l}\text { Impact categories, indicators and } \\
\text { characterization model are common } \\
\text { and internationally accepted }\end{array}$ \\
\hline
\end{tabular}


Table 5.5 (continued)

\section{Requirements for "impact assessment" phase and correspondence of this LCA}

\begin{tabular}{|l|l|}
\hline ISO 14044 Requirement & \multicolumn{1}{|c|}{ This LCA } \\
\hline $\begin{array}{l}\text { Depending on environmental mechanism } \\
\text { "spatial and temporal differentiation of the } \\
\text { characterization model should be } \\
\text { considered" }\end{array}$ & $\begin{array}{l}\text { The climate change impact is on global } \\
\text { and does not require spatial } \\
\text { differentiation. }\end{array}$ \\
$\begin{array}{l}\text { The fossil fuel impact is direct } \\
\text { measurement of fossil fuel used and } \\
\text { differentiation through space and time not } \\
\text { considered. }\end{array}$ \\
\hline $\begin{array}{l}\text { Assignment of LCI results should consider } \\
\text { 1) assignment of LCI results that are } \\
\text { exclusive to one category, and those that } \\
\text { relate to more than one category (and if the } \\
\text { impact and mechanisms are either parallel } \\
\text { or serial) }\end{array}$ & $\begin{array}{l}\text { Fossil energy use and GHG impacts are } \\
\text { related directly since combustion of fossil } \\
\text { fuel emits greenhouse gases. Because of } \\
\text { goal and scope, each requires separate } \\
\text { consideration. }\end{array}$ \\
\hline $\begin{array}{l}\text { Method of calculation of category indicator } \\
\text { results (characterization) is identified }\end{array}$ & Yes. See converting data discussion 5.3.1 \\
\hline $\begin{array}{l}\text { Optional elements of LCIA are 1) } \\
\text { normalization, 2) grouping, 3) weighting, 4) } \\
\text { data quality analysis }\end{array}$ & Not done \\
\hline $\begin{array}{l}\text { Additional analysis depends on need for } \\
\text { accuracy and detail in goal and scope and } \\
\text { could include 1) gravity analysis, 2)- } \\
\text { uncertainity analysis, and 3) sensitivity } \\
\text { analysis }\end{array}$ & $\begin{array}{l}\text { See 5.4 for uncertainty and sensitivity } \\
\text { analysis }\end{array}$ \\
\hline $\begin{array}{l}\text { Comparative LCAs should use } \\
\text { comprehensive set of category indicators } \\
\text { and limitations of LCA should be } \\
\text { recognized }\end{array}$ & $\begin{array}{l}\text { This is comparative LCA, and only two } \\
\text { indicators used. }\end{array}$ \\
\hline
\end{tabular}

\subsubsection{Converting data discussion}

Converting the values collected in the inventory stage to fossil energy and GHG values is a simple arithmetic process. The first step in this process was to locate or derive 
conversion factors. Approximately 40 different factors were required for this study, a list of several of these is shown in table 5.6 to illustrate the procedure and equivalent information for all factors is presented in Appendix $\mathrm{H}$.

Table 5.6 - Selected examples of conversion factors used in study

\begin{tabular}{|c|c|c|c|c|}
\hline Unit & $\begin{array}{l}\text { Fossil } \\
\text { energy } \\
\text { factor }\end{array}$ & Source and comment & $\begin{array}{l}\text { GHG } \\
\text { factor }\end{array}$ & $\begin{array}{l}\text { Source and } \\
\text { comment }\end{array}$ \\
\hline Diesel & $47.2 \mathrm{MJ} / 1$ & $\begin{array}{l}\text { HHV of diesel (Env } \\
\text { Can, 2006) increased by } \\
\text { ratio of upstream } \\
\text { energy inputs from } \\
\text { GHGenius (2007) }\end{array}$ & $\begin{array}{l}3.45 \mathrm{~kg} \\
\mathrm{CO}_{2} \mathrm{eq} / 1\end{array}$ & GHGenius (2007) \\
\hline Electricity & $\begin{array}{l}0.92 \mathrm{btu} / \\
\text { btu } \\
\text { delivered }\end{array}$ & $\begin{array}{l}\text { Fossil energy (coal and } \\
\text { natural gas) portion of } \\
\text { Ontario grid mix } \\
\text { modeled into GREET } \\
\text { (2007) to derive this } \\
\text { factor }\end{array}$ & $\begin{array}{l}0.22 \mathrm{~kg} \\
\mathrm{CO}_{2} \mathrm{eq} / \\
\mathrm{KWhr}\end{array}$ & $\begin{array}{l}\text { Env Canada (2007) } \\
\text { Ontario inventory } \\
\text { factor }\end{array}$ \\
\hline $\begin{array}{l}\text { Nitrogen } \\
\text { fertilizer }\end{array}$ & $\begin{array}{l}44.94 \\
\mathrm{MJ} / \mathrm{kg} \text { of } \\
\mathrm{N}\end{array}$ & $\begin{array}{l}\text { From GHGenius and } \\
\text { based on US Census } \\
\text { data of fertilizer plants } \\
\text { from early } 1990 \text { s with } \\
\text { predicted efficiency } \\
\text { gains. Incorporates } \\
\text { mining, processing and } \\
\text { extraction. }\end{array}$ & $\begin{array}{l}2.98 \mathrm{~kg} \\
\mathrm{CO}_{2} \mathrm{eq} \\
/ \mathrm{kg} \text { of } \mathrm{N} \\
+ \\
3.7 \mathrm{~kg} \\
\mathrm{CO}_{2} \mathrm{eq} / \\
\mathrm{kg} \text { of N }\end{array}$ & $\begin{array}{l}\text { Two factors } \\
\text { required. One to } \\
\text { model the emissions } \\
\text { from manufacturing } \\
\text { the fertilizer (source } \\
\text { GREET, 2007) and } \\
\text { another to model the } \\
\mathrm{N}_{2} 0 \text { emissions from } \\
\text { soil (IPCC, } \\
\text { GHGenius, Grant et } \\
\text { al 2006) }\end{array}$ \\
\hline Enzyme & $\begin{array}{l}90 \mathrm{MJ} / \\
\mathrm{kg}\end{array}$ & $\begin{array}{l}\text { Extracted from } \\
\text { GHGenius - original } \\
\text { source not clear }\end{array}$ & $\begin{array}{l}0.069 \mathrm{~kg} \\
\mathrm{CO}_{2} \mathrm{eq} / \\
\mathrm{MJ}\end{array}$ & $\begin{array}{l}\text { Assumption that all } \\
\text { energy inputs are } \\
\mathrm{NG}-\text { low certainty }\end{array}$ \\
\hline
\end{tabular}

Once a factor was selected, the value collected in the inventory was converted with the help of an Excel spreadsheet. For example, the inventory value for diesel fuel used during planting corn is first divided by the yield of corn per acre and then multiplied by the 
fossil energy factor and the GHG factor. This value is summed with data from other steps and finally expressed in the functional unit. Impacts from electricity use were calculated based on the regional grid approach, which proportions out the amount of Ontario electricity from fossil fuel and other sources. Another possible conversion model, the marginal fuels approach that considers that any marginal increase to be met by the type of electricity production that is most able to ramp up to meet demand (e.g., coal or natural gas) was not used.

Some of the conversion factors are well studied and relatively certain (e.g., energy content of fuel). Other factors are less certain and rely on best guess assumptions (e.g., all production energy for making enzymes is derived from natural gas). Where the factor is highly uncertain or has a large influence on results, the sensitivity of different possible conversion factor values was calculated as part of the life cycle interpretation. 


\subsection{Life cycle interpretation}

Table 5.7: Requirements for "interpretation" phase (adapted from ISO 14044, 2006b) and correspondence of this LCA

\begin{tabular}{|l|l|}
\hline ISO 14044 Requirement & \multicolumn{1}{|c|}{ This LCA } \\
\hline Life Cycle Interpretation & \\
\hline $\begin{array}{l}\text { Shall consider, appropriateness of system } \\
\text { functions, functional unit and system boundary } \\
\text { and any limitations identified by data quality } \\
\text { assessment and sensitivity analysis }\end{array}$ & $\begin{array}{l}\text { More emphasis should be placed on } \\
\text { drawing conclusions from the } \\
\text { foreground stages where data quality } \\
\text { and reach are more certain }\end{array}$ \\
\hline $\begin{array}{l}\text { Identify the significant issues (could include } \\
\text { significant contributions from particular stages } \\
\text { or unit processes, impact categories) }\end{array}$ & $\begin{array}{l}\text { Results are organized by life cycle } \\
\text { stage }\end{array}$ \\
\hline $\begin{array}{l}\text { Evaluation stage establishes confidence in } \\
\text { results of the study and should include } \\
\text { completeness check, sensitivity check and } \\
\text { consistency check }\end{array}$ & $\begin{array}{l}\text { Checks find robust overall results but } \\
\text { uncertainty in individual life cycle } \\
\text { stage results See confidence in results } \\
\text { discussion section 5.4.1 }\end{array}$ \\
\hline $\begin{array}{l}\text { Make preliminary conclusions based on above } \\
\text { and check against initial goal and scope of study } \\
\text { and issue final conclusions and } \\
\text { recommendations }\end{array}$ & $\begin{array}{l}\text { Conclusions and recommendations } \\
\text { reported in section six of thesis }\end{array}$ \\
\hline
\end{tabular}

\subsubsection{Confidence in results discussion}

The results of the LCA are only as good as the data that underlies the output and evaluations of LCA findings are recommended (table 5.7). Several checks were performed. The key finding of the completeness / consistency check (table 5.8) is that data quality is reduced in the background life cycle stages, and more confidence should be placed on results from the foreground life-cycle stages. 
Table 5.8: Completeness check - implications of incomplete or inconsistent data

\begin{tabular}{|c|c|}
\hline $\begin{array}{l}\text { Missing or incomplete or inconsistent } \\
\text { data }\end{array}$ & Implications on goal and scope of study \\
\hline $\begin{array}{l}\text { Ethanol plant data in both E.Ont and S.Ont } \\
\text { cases rely on proxy data from a ethanol } \\
\text { plant in entirely separate location }\end{array}$ & $\begin{array}{l}\text { The proxy data is reliable and corresponds } \\
\text { to reported literature values. Thus the } \\
\text { overall goal of the study which is to } \\
\text { provide an LCA of Ontario ethanol blend } \\
\text { gasoline production is not impacted. } \\
\text { However, a major objective in thesis is to } \\
\text { explore regional differences in ethanol } \\
\text { blend gasoline. The non-regionally specific } \\
\text { data for this life-cycle stage means that } \\
\text { tentative regional conclusions in ethanol } \\
\text { plant activities can be drawn from LCA } \\
\text { results. }\end{array}$ \\
\hline $\begin{array}{l}\text { Data collection by producer differs in } \mathrm{E} \text {. } \\
\text { Ont vs. S. Ont }\end{array}$ & $\begin{array}{l}\text { S.Ont farm data is taken from better record } \\
\text { keeper and likely more consistent and } \\
\text { reproducible than E.Ont data. Both sets of } \\
\text { information have external validity when } \\
\text { compared to provincial values and thus not } \\
\text { considered a problem in reaching goal of } \\
\text { study. Note that the two producers provide } \\
\text { insight into regional variation but are not } \\
\text { statistically representative. }\end{array}$ \\
\hline $\begin{array}{l}\text { Boundary of background life cycle stages } \\
\text { imprecise and data of different geographic } \\
\text { and temporal quality }\end{array}$ & $\begin{array}{l}\text { More confidence in results from } \\
\text { foreground stages } \\
\text { Legitimate comparisons can still be made } \\
\text { in background life cycle stages since } \\
\text { internally consistent data is used (i.e, same } \\
\text { quality, same boundaries) }\end{array}$ \\
\hline
\end{tabular}

Next a sensitivity check was conducted to assess sensitivity of the results to uncertainty in the data. Uncertainty can arise from uncertain confidence in the original data value, uncertain confidence in conversion factors, multiple possible system boundaries or 
allocation methods (ISO 2006a). Values were manipulated over a range and the impact on final results calculated to determine sensitivity. A change of more than $10 \%$ is considered significant (ISO 2006b). The purpose of this exercise is to identify, and improve if possible, the confidence in variables that can change the results. The most important finding from this series of checks (table 5.9) was that the overall results are not significantly changed by uncertainty in the LCA variables and are therefore relatively robust.

However, potential uncertainty in six variables does introduce significant change in results for individual life-cycle stage. These are: syncrude oil recovery energy, rates of nitrogen fertilizer use, the method of allocation, the factor for estimating $\mathrm{CO}_{2} \mathrm{eq}$ emissions when natural gas is burned, the factor for energy required to make nitrogen fertilizer, and the choice to consider energy required to make machinery in the system boundary. Each of these is examined in turn to assess the likelihood that the variable is as variable as modeled in the sensitivity check.

The energy required to extract syncrude oil is taken from a 2003 report on oil sands cited in GHGenius (2007b p.4). As indicated earlier, it is difficult to find specific detailed nonaggregated energy data for the oil industry. Syncrude corporation (2006) cites an increase in energy use of $8 \%$ between 2003 and 2006 and this can be taken as evidence that the value in the LCA model is not as variable as the $25 \%$ change modeled in the sensitivity check. A $25 \%$ change in fertilizer rate applied to corn is also unlikely as application is measured, sometimes with the help of GIS in the S.Ont case. 
Table 5.9: Summary of sensitivity checks

\begin{tabular}{|c|c|c|}
\hline \multicolumn{3}{|c|}{ Inventory data } \\
\hline Input altered by $25 \%$ & $\begin{array}{l}\text { Final result } \\
\text { changes by }> \\
10 \% ?\end{array}$ & $\begin{array}{l}\text { Life cycle stage result } \\
\text { changes by }>10 \% \text { ? }\end{array}$ \\
\hline $\begin{array}{l}\text { Syncrude oil recovery energy inputs } \\
\text { reduced in S.Ont case }\end{array}$ & No $(-2.64 \%)$ & Yes $(-25 \%)$ \\
\hline $\begin{array}{l}\text { Energy use at blending terminal increased } \\
\text { (to check } 20 \text { year old data) }\end{array}$ & No $(+0.10 \%)$ & No $(+5.6 \%)$ \\
\hline $\begin{array}{l}\text { Nitrogen fertilizer reduced in E.Ont on } \\
\text { GHG (large source) }\end{array}$ & No $(-0.14 \%)$ & Yes $(-12.5 \%)$ \\
\hline $\begin{array}{l}\text { Decrease combine fuel use in E.Ont by } 25 \% \\
\text { (uncertain data quality) }\end{array}$ & No $(-0.02 \%)$ & No $(-2.38 \%)$ \\
\hline Yield at ethanol plant increases by $25 \%$ & No $(-0.06 \%)$ & No $(-6.45 \%)$ \\
\hline \multicolumn{3}{|c|}{ Allocation approach } \\
\hline Input altered by $25 \%$ & $\begin{array}{l}\text { Final result } \\
\text { changes by }> \\
10 \% \text { ? }\end{array}$ & $\begin{array}{l}\text { Life cycle stage result } \\
\text { changes by }>10 \% \text { ? }\end{array}$ \\
\hline $\begin{array}{l}\text { Mass based allocation for DDGS and } \mathrm{CO}_{2} \\
\text { co-products instead of system displacement }\end{array}$ & No $<1 \%$ & Yes $(-48 \%)$ \\
\hline $\begin{array}{l}\text { Market based allocation (Wang et al 2004) } \\
\text { instead of mass allocation for non-gasoline } \\
\text { oil products }\end{array}$ & No $(+1.8 \%)$ & Yes $(+14 \%)$ \\
\hline \multicolumn{3}{|c|}{ Conversion factors / co-efficients } \\
\hline Factor changes by $25 \%$ & $\begin{array}{l}\text { Final result } \\
\text { changes by }> \\
10 \% \text { ? }\end{array}$ & $\begin{array}{l}\text { Life cycle stage result } \\
\text { changes by }>10 \% \text { ? }\end{array}$ \\
\hline $\begin{array}{l}\text { Increase natural gas } \mathrm{CO}_{2} \text { eq emission factor } \\
\text { and ethanol plant (varies in different } \\
\text { databases) }\end{array}$ & No $(+0.31 \%)$ & Yes $(+28.4 \%)$ \\
\hline $\begin{array}{l}\text { Decrease } \mathrm{N}_{2} \mathrm{O} \text { emission rate from soil to } \\
\text { assess this highly variable factor }\end{array}$ & No $(-0.3 \%)$ & No $(-7.5 \%)$ \\
\hline Increase energy to make nitrogen fertilizer & No $(+0.05)$ & Yes $(+10.9 \%)$ \\
\hline \multicolumn{3}{|c|}{ System boundary } \\
\hline If boundary includes... & $\begin{array}{l}\text { Final result } \\
\text { changes by }> \\
10 \% \text { ? }\end{array}$ & $\begin{array}{l}\text { Life cycle stage result } \\
\text { changes by }>10 \% \text { ? }\end{array}$ \\
\hline $\begin{array}{l}\text { Energy required to make machinery (using } \\
\text { Pimental } 2003 \text { data) }\end{array}$ & No $(+0.16 \%)$ & Yes $(+28.1)$ \\
\hline $\begin{array}{l}\text { Energy required to make machinery (using } \\
\text { Farell et al } 2006 \text { data) }\end{array}$ & No $(+0.01 \%)$ & No $(+2 \%)$ \\
\hline $\begin{array}{l}\text { Energy required to support human } \\
\text { labourers (using Hill et al } 2006 \text { data) }\end{array}$ & No $(+0.03 \%)$ & No $(+4.5 \%)$ \\
\hline
\end{tabular}


The allocation approach most in-line with ISO guidance was selected for this LCA. (e.g., system displacement for ethanol co-products, and mass instead of market for gasoline coproducts). This provides some confidence that the LCA results are not skewed by a "bad" allocation choice.

The $\mathrm{CO}_{2}$ eq emission factor chosen in this study for natural gas is derived by GHGenius (2005, p379) from data from small industrial boilers. A different factor was used by Farell et al (2006) for engines and turbines which are not relevant to this stage and thus provides some confidence the correct factor is used in this LCA. In terms of the factor for energy required to make nitrogen fertilizer, the biggest source of variability appears to be the forms of fertilizer. Since energy required for forms used by the farms in this study (liquid UAN and ammonium nitrate) vary by only $3 \%$ (calculated from data in Hood and Kidder, 2002) the choice of a single factor for generic nitrogen fertilizer appears to be appropriate. Note that the energy required to make anhydrous ammonia is $21 \%$ less than that of urea, and suggests the factor should be adjusted if farms are using anhydrous ammonia.

Lastly, depending on the data set used, the choice to expand the boundary to include energy required to make machinery could be significant. In this comparative LCA however it is essential to maintain comparability with the gasoline boundary conditions it is not appropriate to expand the boundary to include machinery production. 


\subsection{Summary: Application of ISO 14044 to this LCA}

This LCA designed for Ontario E5 and gasoline fuel met the ISO 14044 standard well. Only 3 elements out of the 40 reviewed in this self- assessment were missed or incompletely carried out.

Unit process level data was not collected for most of the life cycle stages. The reason for this gap was reliance on secondary databases for the background life cycle stages, or in the case of the ethanol plant information, no consent from the process owners to participate. The implication of this is weaker conclusions for the life cycle stages based on sector level data.

The system boundary established for the gasoline production stages is imprecise. Again the reason for this gap is that the data for the background life cycle stages are taken from an existing database with limited reporting of boundaries. For comparisons which rely on the same background data, (e.g., E.Ont gasoline vs E.Ont E5 fuel both rely on the same set of data for gasoline production) the same boundary conditions are present in both cases and entirely valid comparisons can still be made. In cases where different background processes are compared (e.g., S.Ont E5 fuel relies on syncrude boundary vs. E. Ont E5 fuel which relies on offshore oil boundary) the comparability of the systems is less than ideal.

\section{A small set of impact categories (environmental impacts) are examined. LCAs} ideally should review a comprehensive set of environmental impacts, particularly those 
that compare products. This LCA reports fossil energy and greenhouse gas only. This meets the goal and scope of the study but does have the implication that a location or activity that is shown to have a favourable GHG or energy profile may have shortcomings in other environmental impacts that will not be revealed through this LCA.

While this section has shown it is feasible to apply the ISO 14044 framework to biofuel LCA, it is important to recognize that ISO 14044 provides ground rules but does not prescribe choices for all situation. For example, some form of allocation of environmental burden between co-products is required but the choice of allocation method and the assumptions used in the process remain at the discretion of the analyst. Similarly, entire life cycle stages can be deleted if the goal of the assessment is maintained. Ironically, the systematic application of the ISO guidance in this thesis has shown that conducting a LCA is highly context specific and with many opportunities to alter the design, it is very difficult to conceive of two identically performed LCAs. Thus the challenge of building a biofuel-LCA literature built on the same foundation is less simple than originally conceived. This and other lessons learned during the design and implementation of the LCA, form part of the discussion section at the end of the following chapter. 


\section{Results and Analysis}

This assessment on the need to consider regional variations in biofuel production comprises two approaches. The first is a comparison of fuels produced in southern Ontario compared to eastern Ontario, illustrating the degree to which production processes and outcomes are regionally sensitive. The second component is a comparison of province-wide findings versus regional findings. This approach helps reveal the extent to which more refined regional studies (e.g., S.Ont and E.Ont case studies) provide additional information beyond coarser-level regional studies (the province-wide Gen.Ont case study), and thereby investigates the value of place-based versus regionalized research within a biofuels context.

In both approaches, the comparison drew on LCA methods and results are presented according to life cycle stage as shown in table 6.1. All results are expressed according to the common functional unit employed in the LCA (a $45 \mathrm{~km}$ trip in a light duty vehicle). Additionally, the measures of most interest with this phenomenon are estimates of reductions in fossil fuel consumption and GHG emissions when E5 is substituted for gasoline. The E5 to gasoline comparison is discussed at length in section 6.5 for both the region to region and province to region approaches. This discussion includes an extension of the analysis to consider other closely related forms of corn-ethanol biofuels (E30, E85 and pure ethanol). 
Lastly, recall that the S.Ont and E.Ont case studies exhibit characteristics that typify the southern and eastern portions of the province of Ontario. From this they provide a meaningful suggestion of regional differences (see discussion in section 4.4 for more). However, the extent of regional differences presented here is specific to the case studies, and does not claim statistical accuracy for the regions as a whole.

Table 6. 1 - Organization of results

\begin{tabular}{|l|l|l|}
\hline E5 life cycle stage & $\begin{array}{l}\text { Reference to E5 production } \\
\text { stage diagram (see figure 2.1) }\end{array}$ & $\begin{array}{l}\text { Reference in } \\
\text { Section 6 }\end{array}$ \\
\hline Growing corn & Box \# 1 & 6.1 \\
\hline Converting corn to ethanol & Box \# 2 & 6.2 \\
\hline Oil recovery & Box \# 3 & 6.3 \\
\cline { 1 - 2 } Refining oil to gasoline & Box \# 4 & \multirow{2}{*}{6.4} \\
\hline Blending and storage at terminal & Box \# 5 & \\
\hline Sale and storage at gas station & Box \# 6 & \multirow{2}{*}{6.5} \\
\hline Use in vehicle & Box \# 7 & \\
\hline Complete life cycle & --- & Box \#1 and \#2 \\
\hline Ethanol only & \multicolumn{2}{|l}{} \\
\hline
\end{tabular}

\subsection{LCA Stage 1 - Growing Corn}

\subsubsection{Region to Region Comparison}

A total of 28 different activities (unit processes) were recorded for the corn growing stage in the S.Ont and E.Ont cases. Some activities such as planting and harvesting were common to all regions but tillage passes, fungicide use, and applications of herbicide, manure, and starter fertilizer were either present or absent depending on the case (Appendix C-table C.1). The fact that the activities comprising corn farming differed so greatly between the two suggests that site specific variability in sources and quantities of 
fossil fuel used and greenhouse gas emitted is likely the norm for this life cycle stage across the province.

Overall GHG emissions for this stage are estimated to be $67 \%$ lower and fossil fuel use $84 \%$ lower in the S.Ont case compared to the E.Ont case (Appendix I). The favourability of southern corn production in terms of GHG emissions in this study was so great that hypothetically trucking corn from the S.Ont case farm to the E.Ont ethanol plant (return distance of approx. $1800 \mathrm{~km}$ ) still results is estimated $10 \%$ GHG savings over producing corn in the E.Ont case.

Result 1: Fossil fuel use and GHG intensity of corn production differ between regional cases by a large enough margin to potentially justify - on a fossil fuel and GHG basis only-trucking S.Ont corn to an E.Ont ethanol plant

Table 6.2 - Comparison of top ranked farming activities in S.Ont and E.Ont*

\begin{tabular}{|c|c|c|c|}
\hline \multicolumn{2}{|c|}{ Fossil energy } & \multicolumn{2}{|c|}{ GHG } \\
\hline S.Ont & E.Ont & S.Ont & E.Ont \\
\hline $\begin{array}{l}\text { Drying corn with } \\
\text { natural gas } \\
(42.8 \%)\end{array}$ & $\begin{array}{l}\text { Drying corn grain } \\
\text { with propane } \\
(34.3 \%)\end{array}$ & $\begin{array}{l}\text { Nitrogen fertilizer } \\
\text { applied with seed } \\
(54.5 \%)\end{array}$ & $\begin{array}{l}\text { Nitrogen fertilizer } \\
\text { applied with seed } \\
(47.8 \%)\end{array}$ \\
\hline $\begin{array}{l}\text { Nitrogen fertilizer } \\
\text { applied with seed } \\
(40.0 \%)\end{array}$ & $\begin{array}{l}\text { Nitrogen fertilizer } \\
\text { applied with seed } \\
(31.1 \%)\end{array}$ & $\begin{array}{l}\text { Drying corn with } \\
\text { natural gas } \\
(23.2 \%)\end{array}$ & $\begin{array}{l}\text { Drying corn with } \\
\text { propane } \\
(16 \%)\end{array}$ \\
\hline $\begin{array}{l}\text { Combine diesel fuel } \\
(4.5 \%)\end{array}$ & $\begin{array}{l}\text { Combine diesel fuel } \\
(9.5 \%)\end{array}$ & $\begin{array}{l}\text { Electricity used to } \\
\text { dry corn grain } \\
(8.7 \%)\end{array}$ & $\begin{array}{l}\text { Combine diesel fuel } \\
(7.2 \%)\end{array}$ \\
\hline $\begin{array}{l}\text { Electricity used to } \\
\text { dry corn grain } \\
(4.2 \%)\end{array}$ & $\begin{array}{l}\text { Tractor diesel fuel } \\
\text { for primary tillage } \\
(5.1 \%)\end{array}$ & $\begin{array}{l}\text { Combine diesel fuel } \\
(3.1 \%)\end{array}$ & $\begin{array}{l}\text { Potassium applied } \\
\text { with Nitrogen } \\
(5.2 \%)\end{array}$ \\
\hline $\begin{array}{l}\text { Tractor fuel to plant } \\
(2.2 \%)\end{array}$ & $\begin{array}{l}\text { Diesel used to run } \\
\text { tractor during } \\
\text { drying }(5.0 \%)\end{array}$ & $\begin{array}{l}\text { Nitrogen starter } \\
\text { fertilizer }(1.6 \%)\end{array}$ & $\begin{array}{l}\text { Tractor diesel fuel } \\
\text { for primary tillage } \\
(3.9 \%)\end{array}$ \\
\hline
\end{tabular}

${ }^{*}$ percent of total fossil fuel consumed or GHG emissions emitted in the corn farming stage per $45 \mathrm{~km}$ light duty vehicle trip 
Despite large overall difference between the two locations, there are also relative similarities. Two activities, the use of nitrogen fertilizer and drying corn, dominate fossil fuel and GHG impacts in the corn farming stage for both regional cases, accounting for $60 \%$ to $80 \%$ of totals (table 6.2 ). The fact that the same activities dominate impacts in these two divergent locations may suggest that nitrogen use and drying corn are important variables to consider in all corn production locations.

Differences between the two regional cases are highlighted in figure 6.1. The E.Ont case has higher emissions due to higher nitrogen application at seeding and a higher rate of pre-planting starter fertilizer. Higher fuel inputs are due to presence of additional fuel consuming activities such as cultivation passes that are not part of the S.Ont case and less fuel efficient equipment, particularly the combine in the E.Ont case.

Figure 6.1 - GHG emissions from major activities in E-5 life cycle stage 1 (farming corn) for S.Ont and E.Ont case studies

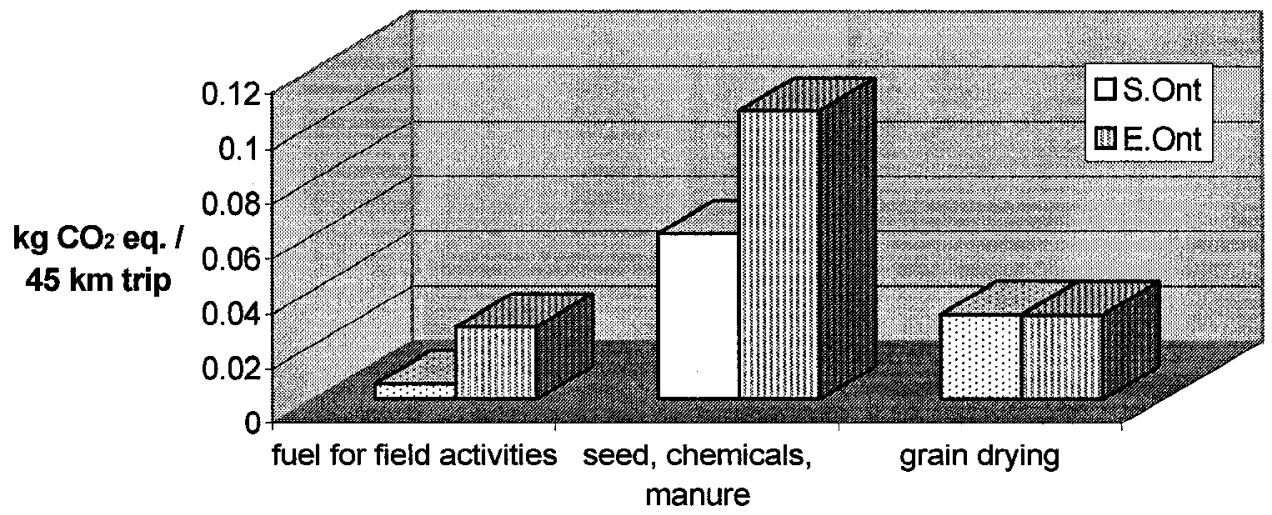


Identifying the factors that account for differences between the two cases leads to insight into which activities should be the target for reducing fossil fuel use and GHG emissions of the system. No-till corn farming practiced in the S.Ont case exhibits fewer field passes and lower emissions, this confirms similar work, (e.g., West and Marland, 2002) that suggests GHG emissions decrease when no-till is practiced. On the other hand, emissions from drying grain are similar in each case (fig 6.1). This activity is dictated by the requirement from ethanol plants for corn with $15.5 \%$ moisture content. Both farms harvested late in the fall when moisture content of corn was low and dried corn down to $15.5 \%$ moisture content with either propane or natural gas. The similarity in these results suggests drying corn may contribute a constant fossil fuel use / GHG emissions to corn farming with little potential for improvement.

\section{Corn yield comments}

The effect that difference in corn yield has on the divergence between the cases is important, and has been identified by Farell et al (2006) as an important source of variation in fuel ethanol LCA results. The case with the higher corn yield should show reduced GHG emissions and fossil fuel use because more corn is produced with roughly the same inputs. Yield in the E.Ont case is $18 \%$ lower than that in the S.Ont case and one would predict (based on an assumption of identical farming activities in each case) approximately $18 \%$ lower GHG emissions for corn in Eastern Ontario. Yet, as shown earlier, the estimated GHG differences between the cases are much higher (67\%). 
To isolate the influence of different yield in the cases, the yield used in the calculation of S.Ont LCA results was adjusted to the yield from the E.Ont. The results for the comparison with this "normalized S.Ont yield" are shown in figure 6.2. While emission increase in the yield adjusted case for fuel inputs and direct field inputs, overall emissions are still substantially lower ( $49 \%$ overall) than the E.Ont case.

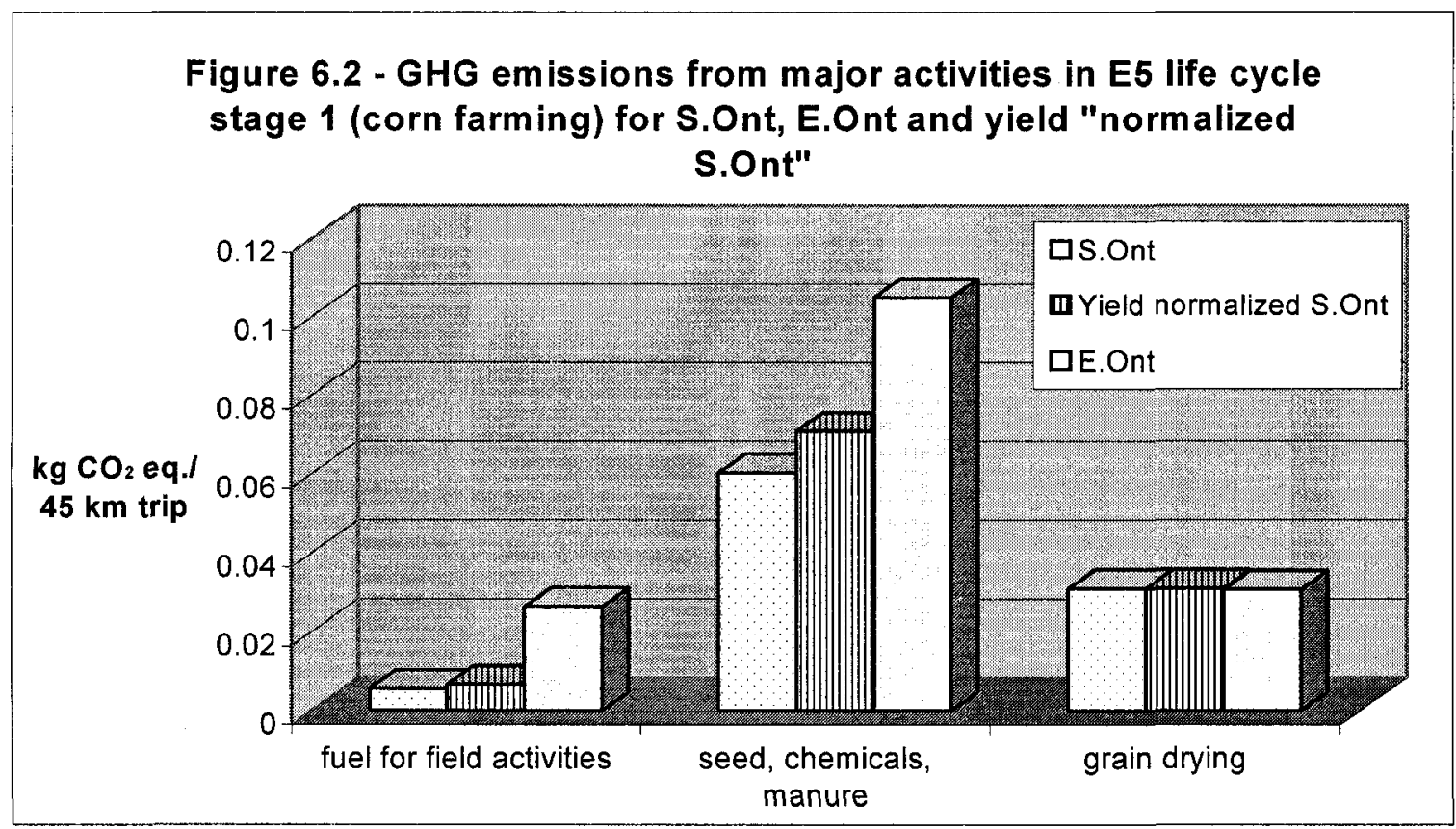

Figure 6.2 illustrate that the E.Ont case farm requires more fuel and more fertilizer (leading to higher GHG emissions) to produce the same amount of corn as the S.Ont case farm (e.g., required more fertilizer and more fuel). It would therefore be a mistake to assume that one could predict success of a corn ethanol GHG reduction strategy that relies on maximizing reductions by focusing on high yielding corn production alone.

Result 2: - Differences in intensity of corn farming impacts between the locations cannot be explained by yield differences alone 


\subsubsection{Provincial to Regional Comparison}

The Gen.Ont case allows for a comparison between results using data taken at a provincial vs. local scale. Remember that the provincial assessment represents the common approach to biofuel LCA and as such represents a kind of base line from which to assess the regional biofuel LCAs completed for the S.Ont case and the E.Ont case. The maximum difference between one of the regional case is $41 \%$ higher fossil fuel use in E.Ont and 25\% lower $\mathrm{CO}_{2}$ eq emissions in S.Ont (see Appendix I, table I.3). This difference is a potential indication of the margin of error one could potentially expect for this life-cycle stage when relying only on provincial data.

Result 3: Significant differences were found between fossil fuel consumption and GHG emissions in the corn production stage between provincial and regional E5 LCA results introducing the possibility of a margin of error for estimates of fossil fuel use in the corn production life cycle stage of up to $40 \%$ when relying only on provincial LCA. 


\subsection{LCA Stage 2 - Converting corn to ethanol}

\subsubsection{Region to Region Comparison}

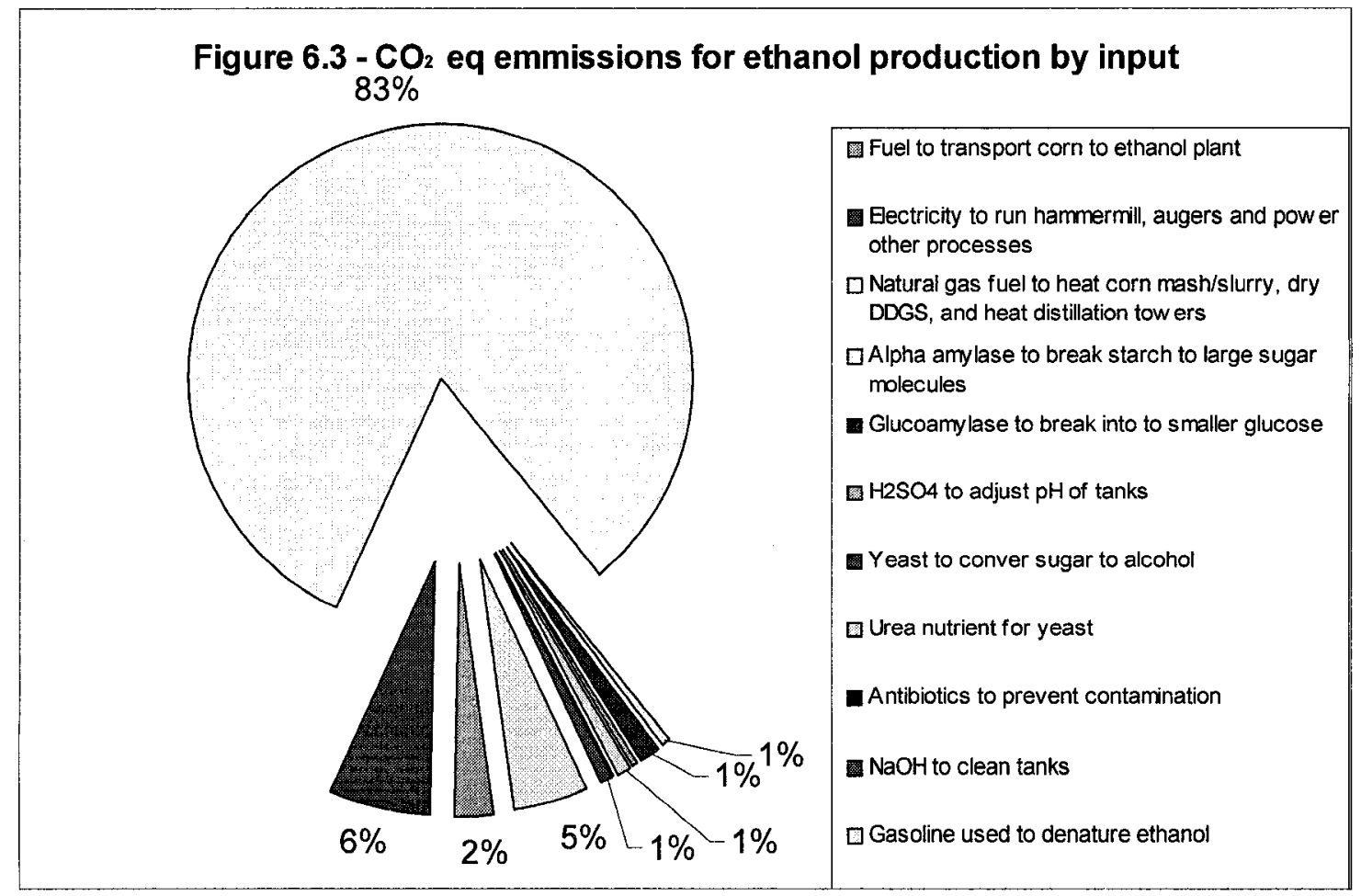

The second life cycle stage examined was that of converting corn to ethanol. The activities of this process are identical in both regional cases. The use of natural gas is by far the largest contributor to fossil fuel use and greenhouse gas emissions (figure 6.3). Reducing natural gas use or substituting a less greenhouse gas intensive fuel could reduce overall impacts for this stage substantially. Indeed, the higher greenhouse gas savings reported in the literature for sugarcane ethanol production over corn ethanol production are in large part due to the use of a biofuel (cane stalks with sugar extracted - "bagasse") as the industrial heat source for this life cycle stage (Dias de Oliveira et al, 2005). 
Table 6.3 compares overall fossil fuel use and $\mathrm{CO}_{2}$ eq emissions for the three cases. Note that the similarity in the results for the regional cases for this stage is an artifact of the data because the inputted data come from the same source.

Table 6.3 - Totals from E5 life cycle stage 2 - converting corn to ethanol

\begin{tabular}{|l|r|r|r|}
\hline & Gen.Ont & S.Ont & E.Ont \\
\hline Total $\mathrm{CO}_{2}$ eq/ car trip & $1.09 E-01$ & $1.06 E-01$ & $1.10 E-01$ \\
\hline Total $\mathrm{MJ} /$ car trip & $2.35 E+00$ & $2.17 E+00$ & $2.23 E+00$ \\
\hline
\end{tabular}

This is the stage of E5 production where the co-products DDGS and commercial $\mathrm{CO}_{2}$ are produced. The fossil fuel and greenhouse gas burden of producing these products in an alternative process has been calculated (see section 5.2.2) and subtracted from totals for this stage. Allocation changes the burden of the entire ethanol production process (e.g., ethanol manufacturing plus corn farming) by a ratio of 0.79 for GHG emissions and 0.88 for fossil energy use. This ratio is on the high end of the range of allocation factors for ethanol production identified in Hammerschlag (2006), indicating that the allocation performed in this study was relatively conservative and does not underestimate the portion of the total fossil fuel and GHG burden associated with ethanol.

Result 4: Future biofuel LCA studies should consider allocating environmental burden to the commercial $\mathrm{CO}_{2}$ product produced during the ethanol manufacturing stage

Including an allocation procedure for commercial $\mathrm{CO}_{2}$ is a new concept in corn-ethanol LCA work. None of the studies reviewed by Hammerschlag (2006) considered commercial $\mathrm{CO}_{2}$ production as a co-product. In this study the procedure did not lead to a substantial divergence from the literature results and one could argue that it is therefore 
not important to include this process in the LCA allocation procedure. However, it is worth remembering that the sensitivity analysis in section 5.4 showed that under alternate allocation methods the $\mathrm{CO}_{2}$ product alone reduces burden allocated to ethanol by one third. Thus, future biofuel LCA work, particularly those using mass or volume based allocation procedures should continue to consider commercial $\mathrm{CO}_{2}$ production as well as DDGS.

\subsubsection{Provincial to Regional Comparison}

In contrast to the previous life cycle stage, estimates of GHG emissions and fossil fuel consumption derived from the provincial assessment is very similar to that from the regional cases. In the corn production stage the Gen.Ont and regional case study values differed by up to $40 \%$, but in the ethanol conversion stage total difference was approximately $2 \%$. This result is surprising. Provincial data is based on a combination of literature and industry published data values from up to 10 years ago, while that for S.Ont and E.Ont is current information from interviews with ethanol plant managers.

Result 5: Results for the ethanol conversion stage differed only slightly when using generic provincial data versus regional data. There appears to be little need to collect sub-provincial data for this stage

The reason for the similarity between cases is likely due to the standard conditions that characterize the ethanol manufacturing plant. Unlike the farming stage where conditions vary due to weather, pests, and management preferences, the ethanol plant is an industrial system with closely monitored conditions relying on calibrated machinery. The quantities of inputs to the process and corresponding levels of fossil fuel consumed and greenhouse gases emitted appear to remain close to the average for the industry even in 
newer plants. A tentative conclusion from this result is that corn ethanol biofuel LCAs in Ontario can rely on generic literature data for dry mill plants instead of local data collection for the ethanol manufacturing stage.

A related observation is that expanding the boundary in this life cycle stage to include items not reported in the literature (enzyme use, antibiotics, yeast use) did not impact the results significantly. The fossil fuel and GHG impacts of these activities are factors of magnitude below that of the major sources and can be excluded without meaningfully changing the overall result.

\subsection{LCA Stages $3 \& 4$ - Gasoline production stages}

\subsubsection{Region to Region Comparison}

Impacts from the gasoline production stages will contribute much more to the E5 total than the previous stages simply because there is more gasoline in the product than ethanol. The overwhelming point to take from the results (table 6.4) is that the S.Ont case has much higher impacts on the environment (60\% higher fossil fuel and $31 \%$ higher GHG emissions) than the E.Ont case for these life cycle stages. Most of the difference is from the oil extraction stage where greenhouse gas emissions are 112\% higher and fossil fuel use is $225 \%$ higher in S.Ont than in E.Ont. The higher impacts are due to extraction of viscous oil sand oil and conversion to synthetic crude, which is more polluting and energy intensive than extraction of North Sea offshore oil in the case of the E.Ont case, even when considering the increased transport distance. 
Table 6.4: Fossil fuel use and greenhouse gas emissions per $45 \mathrm{~km}$ car trip from gasoline production stages of $\mathbf{E} 5$ production

\begin{tabular}{|c|c|c|c|c|c|c|c|}
\hline \multirow{2}{*}{\multicolumn{2}{|c|}{ Activity }} & \multicolumn{2}{|l|}{ Gen.Ont } & \multicolumn{2}{|l|}{ S.Ont } & \multicolumn{2}{|l|}{ E.Ont } \\
\hline & & MJ & $\mathrm{CO}_{2} \mathrm{eq}$ & MJ & $\mathrm{CO}_{2} \mathrm{eq}$ & MJ & $\mathrm{CO}_{2} \mathrm{eq}$ \\
\hline $\begin{array}{l}\text { Stage } \\
3\end{array}$ & $\begin{array}{l}\text { Crude oil } \\
\text { extraction }\end{array}$ & 17.2 & 1.07 & 23.5 & 1.30 & 7.22 & 0.612 \\
\hline \multirow[t]{2}{*}{$\begin{array}{l}\text { Stage } \\
4\end{array}$} & $\begin{array}{l}\text { Oil refining } \\
\text { to gasoline }\end{array}$ & 28.7 & 2.29 & 30.2 & 2.34 & 26.3 & 2.15 \\
\hline & $\begin{array}{l}\text { Transport } \\
\text { component } \\
\text { of refining }\end{array}$ & 2.06 & 0.166 & 2.12 & 0.171 & 3.29 & 0.270 \\
\hline \multicolumn{2}{|c|}{ Total stages $3 \& 4$} & 45.9 & 3.36 & 53.7 & 3.64 & 33.5 & 2.77 \\
\hline
\end{tabular}

This result reverses the trend seen in the earlier life cycle stages where the E.Ont case was more polluting. When all the stages are considered together later in the results section it is shown that the higher burden for the S. Ont gasoline production case will end up dwarfing the more favourable burden from earlier life cycle stages.

Result 6: Extraction of crude oil for use in E5 and gasoline in the S.Ont case is $225 \%$ more fossil energy intensive and $112 \%$ more greenhouse gas intensive than the E.Ont case.

\subsubsection{Provincial to Regional Comparison}

For this life cycle stage the results from the provincial scale differ substantially with those from the local scale. The provincial assessment provides estimates of fossil fuel that are 58\% higher than the E. Ont case and estimates of GHG emissions that are $43 \%$ higher for the crude oil extraction stage (Appendix I, table I.4). The precision of these values is tempered by the knowledge of imprecise data quality and system boundaries for this 
stage (section 5.1 and 5.2). However, it appears that again the use of provincial scale data will mask a significant local difference in E5 production conditions.

The large intra-provincial difference for these stages was unexpected. Unlike corn farming where regional variability is conferred by thousands of producers over the province, crude oil is extracted in fewer locations across the continent and Ontario could reasonably have been expected to be supplied by fewer and less diverse suppliers with similar fossil fuel and GHG emissions. A sub-provincial data focus, however, has identified a range of suppliers and crude types for the province.

There appear to be areas of the province where biofuel blends provide better GHG return on investment. The S.Ont example has higher than average gasoline greenhouse gas emissions and it is here that the difference between ethanol and gasoline are greatest.

\subsection{LCA Stages 5,6\& 7 - Blending, Sale and Use stages}

\subsubsection{Region to Region Comparison}

Blending is stage \#5 in this assessment (table 6.5). Differences between the cases are due to different transport distances required to move gasoline and ethanol to the fuel terminal.

Table 6.5 - GHG impacts for blending E5 fuel

\begin{tabular}{|l|l|l|l|}
\hline & Gen.Ont & S.Ont & E.Ont \\
\hline Total $\mathrm{CO}_{2}$ eq / $45 \mathrm{~km}$ trip & 0.085 & 0.091 & 0.083 \\
\hline
\end{tabular}

There are no differences in the results for stage 6 (sale of product) as the retail fuel stations are considered identical background processes in this study. Per functional unit total fossil energy use for this stage is $0.86 \mathrm{MJ}$ and $\mathrm{GHG}$ emissions are $0.05 \mathrm{~kg} \mathrm{CO}_{2}$ eq. 
There are also no differences between locations for the use stage for E5 fuel. These were held constant in this study as there is no evidence of a regional difference in vehicle fleets. Total fossil fuel consumed and greenhouse gas emitted during use are very high in comparison to the other life cycle stages. Fossil fuel use is $165 \mathrm{MJ} /$ car trip and $11.1 \mathrm{~kg}$ of $\mathrm{CO}_{2}$ eq . / car trip for E5 and $170 \mathrm{MJ} /$ car trip and $11.5 \mathrm{~kg}$ of $\mathrm{CO}_{2}$ eq. / car trip for pure gasoline regardless of regional case.

\subsubsection{Provincial to Regional Comparison}

The blending stage is the only one of the latter life cycle stages where local data was used and can be compared to the provincial assessment. The maximum difference for this stage is $15 \%$ from the S.Ont case indicating that there may be a need to conduct LCA at a local scale for this stage of the assessment. If so, the variable to monitor is distance that ethanol is trucked to the blending depot.

\subsection{Complete life cycle results}

\subsubsection{Region to Region Comparison}

When results from all stages are assembled together several points emerge. First of these is an answer to the question of whether or not E5 provides potential fossil fuel and greenhouse gas reductions in Ontario. The activities to produce corn, produce ethanol, and to distribute the ethanol product, increase the fossil fuel and GHG burden of E5. However, ultimately the net result is a slight reduction in all three E5 cases (table 6.6. full results in Appendix I). 
Table 6.6 - Benefits when using E5 versus gasoline based on life cycle comparison on three Ontario cases

\begin{tabular}{|l|c|c|}
\hline \multicolumn{1}{|c|}{ Life cycle stage } & Fossil fuel reduced? & $\begin{array}{c}\text { Greenhouse gas } \\
\text { emissions reduced? }\end{array}$ \\
\hline Farming corn & $\mathrm{X}$ & $\mathrm{X}$ \\
\hline Manufacturing ethanol & $\mathrm{X}$ & $\mathrm{X}$ \\
\hline Extracting crude oil & $\sqrt{ }$ \\
\hline Refining oil to gasoline & $\sqrt{ }$ & $\mathrm{V}$ \\
\hline Distribution, blending, storage & $\mathrm{X}$ & $\mathrm{X}$ \\
\hline Use of fuel in vehicle & $\sqrt{ }$ \\
\hline OVERALL & $\sqrt{ }$ & $\sqrt{ }$ \\
\hline
\end{tabular}

The "use" stage is overwhelmingly important to the total. Results for the Gen.Ont E5 case are shown graphically in figure 6.4 (the S.Ont and E.Ont cases show the same relationship - see Appendix I, Table I.1 for full results). In terms of improving the environmental performance of E5, the use stage is key and increasing the fuel economy of cars is one obvious way to reduce the impacts. The significance of a higher fuel economy for ethanol blends is modelled later in this section. Note that the relative fossil fuel and GHG intensity of the final use stage will drop as the portion of gasoline drops in higher E-blends, this scenario is also modelled later in section 6.5.3.

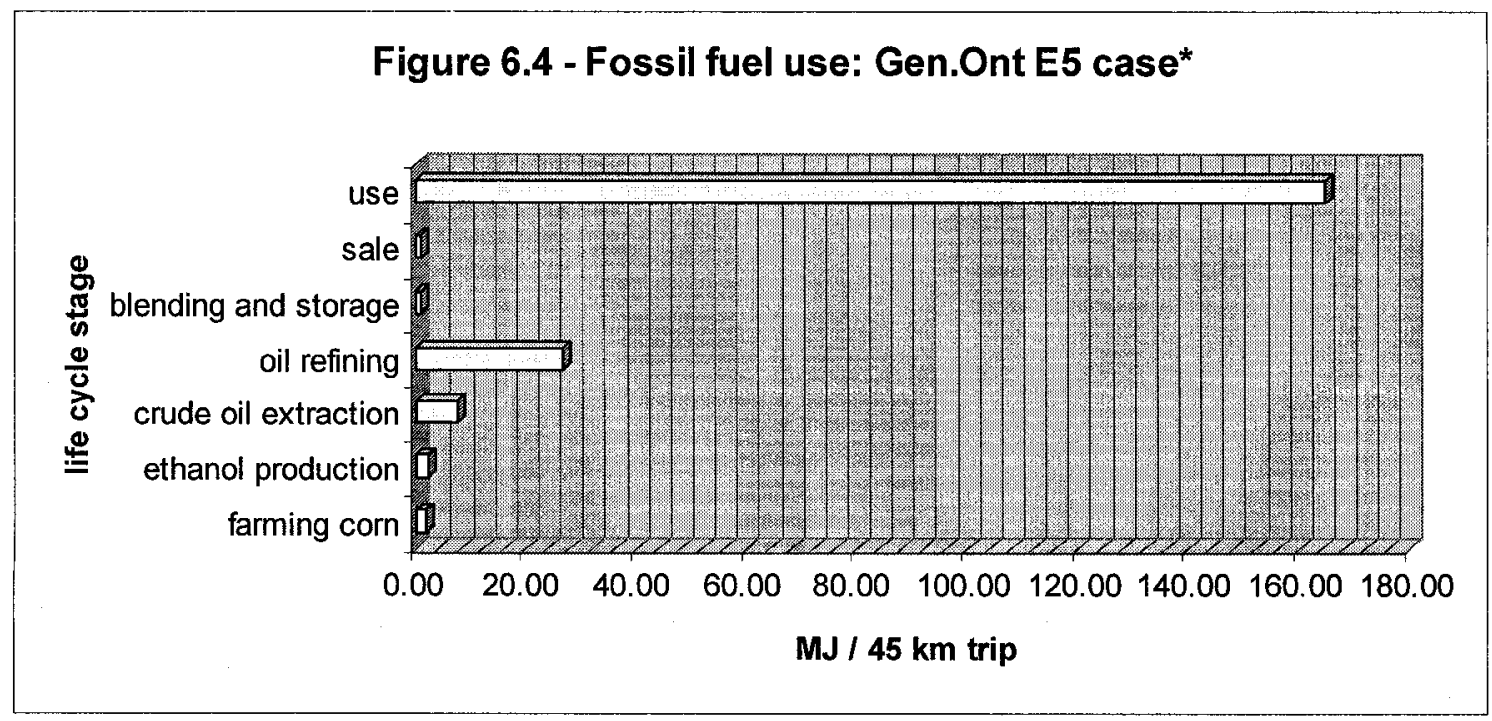


The second major finding that emerges when all life cycle results are assembled is that E5 in the E.Ont case emits fewer greenhouse gases (5.6\%) than Southern Ontario E5 and consumes less fossil energy (9.8\%) (table.6.7). However, when the E5 option in each case is compared to the gasoline made in the same region, the S.Ont E5 case offers more favourable reductions $\mathrm{GHG}(1.3 \%$ vs. $0.7 \%)$ and fossil fuel reductions (1.3\% vs. $1.0 \%)$ than use of E5 in the E.Ont case.

Table 6.7: Comparing complete life-cycle GHG emissions and fossil fuel consumption for S.Ont and E.Ont regional case studies

\begin{tabular}{|c|c|c|}
\hline \multicolumn{3}{|c|}{ (I) GHG Emissions } \\
\hline \multirow{7}{*}{$\begin{array}{l}\text { Total GHGs } \\
\text { (kg CO} 2 \mathrm{eq} / \\
45 \mathrm{~km} \text { trip) }\end{array}$} & E.Ont E5 & 14.3 \\
\hline & S.Ont E5 & 15.1 \\
\hline & $\%$ difference E.Ont vs. S.Ont & $-5.6 \%$ \\
\hline & E.Ont gasoline & 14.4 \\
\hline & $\%$ difference E.Ont E5 vs. E.Ont gas & $-0.70 \%$ \\
\hline & S.Ont gasoline & 15.3 \\
\hline & $\%$ difference S.Ont E5 vs. S.Ont gas & $-1.3 \%$ \\
\hline \multicolumn{3}{|c|}{ (II) Fossil Fuel consumption } \\
\hline \multirow{7}{*}{$\begin{array}{l}\text { Total Fossil } \\
\text { fuel use } \\
\text { (MJ } \\
/ 45 \mathrm{~km} \text { trip) }\end{array}$} & E.Ont E5 & 204 \\
\hline & S.Ont E5 & 224 \\
\hline & $\%$ difference E.Ont vs. S.Ont & $-9.8 \%$ \\
\hline & E.Ont gasoline & 206 \\
\hline & $\%$ difference E.Ont E5 vs. E.Ont gas & $-1.0 \%$ \\
\hline & S.Ont gasoline & 227 \\
\hline & \% difference S.Ont E5 vs. S.Ont gas & $-1.3 \%$ \\
\hline
\end{tabular}

* See Appendix I table I.1 for full results 
Result 7: E5 from the E. Ont case uses less fossil fuel and emits fewer greenhouse gases, but $S$, Ont E5 has a better GHG reduction return compared to gasoline

In order of lowest to highest GHG emissions the most favourable fuels are:

\section{E.Ont E5 $\rightarrow$ E.Ont gasoline $\rightarrow$ S.Ont E5 $\rightarrow$ S.Ont gasoline}

Note that the E.Ont gasoline product is estimated to use less fossil fuels and emit fewer greenhouse gases than the S.Ont E5 product. This particular comparison is slightly fatuous however as blended ethanol is not transported for sale between the two regions, instead pure ethanol is delivered to fuel terminals throughout the province and blended at these terminals. The gasoline product, on the other hand, is transported over longer distances and the slightly more likely hypothetical scenario is that the petroleum pipeline extending from Sarnia to Montreal (Enbridge, 2002) could be reversed to bring less GHG intensive petroleum from eastern Canada to S.Ont. Even after accounting for the extra pipeline emissions estimated savings of $5.7 \%$ is possible (four fold better return than savings from S.Ont E5) when substituting E.Ont gasoline for S.Ont gasoline.

In any case, these regional LCA results have introduced the possibility that some Ontario E5 product in Ontario has a worse GHG and fossil fuel burden than some Ontario gasoline products. This is particularly possible in a region like Southern Ontario where gasoline is derived from a mix of crude oil types. 


\subsubsection{Provincial to Regional Comparison}

Total life cycle results from the biofuel LCAs conducted provincially and regionally are in broad relative agreement. Both the provincial case estimates (1.3\% fossil fuel reduction, $0.7 \%$ GHG reduction, derived from Appendix I, table I.1) and the estimates for both regional cases (table 6.7) E5 provide slight savings versus gasoline.

In three of the E5 production life cycle stages place based results substantially disagree with those from a provincial scale. These are summarized in table 6.8. When total results including all life cycle stages are considered, the overall error introduced by ignoring local scale data in this study is $5 \%$. The small overall difference and the consistency in conclusions between the three cases lead to a conclusion that little is gained by considering local variation in data when considering low e-blends versus gasoline.

Table 6.8 - Errors introduced by provincial assessment in E5 biofuel LCA

\begin{tabular}{|l|l|l|}
\hline Life cycle stage & $\begin{array}{l}\text { Margin of error } \\
\text { between local scale } \\
\text { and provincial scale }\end{array}$ & $\begin{array}{l}\text { Most important regionally } \\
\text { divergent activities }\end{array}$ \\
\hline Corn farming & $41 \%$ & $\begin{array}{l}\text { Yield, nitrogen fertilizer } \\
\text { rates and field machinery } \\
\text { fuel use }\end{array}$ \\
\hline Ethanol manufacture & $<2 \%$ & Negligible \\
\hline Oil recovery & $58 \%$ & Crude oil type and origin. \\
\hline Gasoline refining & $<5 \%$ & Negligible \\
\hline Blending and storage & $14 \%$ & $\begin{array}{l}\text { Distance ethanol plant to } \\
\text { blending terminal }\end{array}$ \\
\hline Use & $0 \%$ & Negligible \\
\hline Total life cycle & $5 \%$ & - \\
\hline
\end{tabular}

However, this does not mean that that the provincial scale case is accurate in all regions or even that there are negligible intra-provincial differences. Fossil fuel and greenhouse gas emissions for E5 fuels and gasoline in Ontario vary to a large enough extent that pure 
gasoline is favourable to E5 in some instances, and there is a regional dimension to this possibility. The southern region uses gasoline derived from a conventional oil or synthetic crude oil or bitumen (see section 4.1.1) and it is very likely that some southern Ontario gasoline will have a fossil fuel and GHG intensity that is lower than some E5 blends within the same region.

Ultimately, the need to incorporate regional variation in LCA of biofuels depends on the intended use of the results. Users interested solely in whether or not Ontario corn-ethanol can provide net GHG or fossil fuel benefit could rely on provincial assessments.

However, the regional variability seen in the case studies suggests that those interested in maximizing reductions need more local information. The last column of table 6.8 directs future LCA work to the inventory data that dominate regional differences in the cases. This guidance is highly practical as it could allow future LCA to improve spatial representation without having to assemble full data sets for many locations.

\subsubsection{Higher ethanol blends}

While E5 biofuel blends are the most significant transport biofuel in Ontario at present, other blends are slowly emerging (section 4), and it is conceivable that higher ethanol blends will become more prevalent. At higher ethanol blends, the large local differences seen in this study for the ethanol production stages will be magnified, and it is here that regional or place based LCA becomes particularly relevant.

E85 fuel is available in few locations in the province currently but a major vehicle manufacture continues to produce E85 vehicles and it is possible that a niche market for 
E85 may develop. E30 content is also possible. Szklo et al (2008) have indicated that this mixture can burn more efficiently than gasoline with engine compression changed to that of diesel engines and recommend E30 as the optimum blend. Vandergaast (1999) has shown that the eastern Ontario region is capable of supplying enough corn to replace $30 \%$ of gasoline with ethanol in the region with some changes to other crop volumes.

Not suprisingly, at higher blends sharper cuts in GHG and fossil fuel use are seen (table 6.9 - data derived using E5 LCA model paramaters). The use of E30 cuts GHG emissions by $13 \%$ in S.Ont and the use of E85 in the same region cuts GHG emissions by close to half. This data also shows that changing the fuel economy of engines using E30 blends can triple the effectiveness of reductions. Engine design changes should therefore go hand in hand with any decision to ramp up ethanol blends in a biofuel GHG reduction strategy.

Table 6.9 - Fossil energy and greenhouse gas reductions versus gasoline with different ethanol blends per $45 \mathrm{~km}$ car trip

\begin{tabular}{|l|l|l|l|l|}
\hline \multirow{2}{*}{} & \multicolumn{2}{|c|}{ E.Ont } & \multicolumn{2}{c|}{ S.Ont } \\
\cline { 2 - 5 } & $\begin{array}{l}\% \text { fossil } \\
\text { energy } \\
\text { savings }\end{array}$ & $\begin{array}{l}\% \mathrm{CO}_{2} \text { eq } \\
\text { reductions }\end{array}$ & $\begin{array}{l}\% \text { fossil } \\
\text { energy } \\
\text { savings }\end{array}$ & $\begin{array}{l}\% \mathrm{CO}_{2} \text { eq } \\
\text { reductions }\end{array}$ \\
\hline E5 & $1.0 \%$ & $0.7 \%$ & $1.3 \%$ & $1.3 \%$ \\
\hline E30 & $8.9 \%$ & $9.2 \%$ & $13 \%$ & $13 \%$ \\
\hline $\begin{array}{l}\text { E30 (with fuel } \\
\text { economy gain from } \\
\text { engine changes) }\end{array}$ & $26 \%$ & $26 \%$ & $29 \%$ & $29 \%$ \\
\hline E85 & $35 \%$ & $33 \%$ & $47 \%$ & $46 \%$ \\
\hline
\end{tabular}


Result 8: Higher ethanol blends could cut fossil energy use and greenhouse gas emissions compared to gasoline by close to half in Ontario. This scenario appears regionally differentiated, indicating a need for regional or place-based biofuel LCA.

Should higher ethanol blends become more prevalent, production in E.Ont should be carefully considered. The potential savings versus gasoline are less than in S.Ont and because of differences in the agricultural life cycle stage, an E85 biofuel from the eastern region could emit substantially more greenhouse gases than one produced in the south.

\subsubsection{Comparison to literature results}

The biofuel LCA literature is dominated by assessments of ethanol and not of ethanol blends. Perhaps most widely considered is the simple check to see if more energy is available from the fuel than consumed in making the fuel, i.e. is the net energy positive? Since the energy available in a litre of ethanol is a constant 23.58 and total fossil energy inputs per litre for the Gen.Ont case in this study are $14.5 \mathrm{MJ}$, Ontario made ethanol does provide net energy. The fuel has a value of 1.63 "energy return on investment" $\left(\mathrm{r}_{\mathrm{E}}\right)$ when expressed in terms of Hammerschlag's (2006) value (section 3.3).

The 1.63 value is a more favorable energy profile than that of other corn ethanol studies but a little less favourable than that derived from the Canadian federal government model GHGenius. Table 6.10 shows reported and calculated energy return on investment values. The main reason why this study reports low overall fossil energy is from lower reported

Result 9: Ontario ethanol has a better energy return on investment than that reported from other corn-ethanol LCA studies 
ethanol production values. Ontario's ethanol industry is dominated by new natural gas fired ethanol plants. These plants are more efficient than those captured by the data set used in other studies which includes, older less efficient coal-fired plants.

Table 6.10 - Energy return on investment $\left(\mathrm{r}_{\mathrm{E}}\right)$ : Comparison of literature values

\begin{tabular}{|l|l|l|}
\hline Study & $\left(\mathrm{r}_{\mathrm{E}}\right)$ value & $\begin{array}{l}\text { Fossil energy used in } \\
\text { ethanol production stage } \\
\text { (MJ/l of ethanol, } \\
\text { unallocated) }\end{array}$ \\
\hline Graboski (2002) & 1.38 & 14.7 \\
\hline Shapouri et al (2002) & 1.38 & 13.6 \\
\hline Pimentel and Patzek (2005) & 0.84 & 17.1 \\
\hline Kim and Dale (2005) & 1.62 & 14.8 \\
\hline GHGenius version 3.12 (2008)* & 1.72 & 10.4 \\
\hline Base case ethanol from this LCA & $\mathbf{1 . 6 3}$ & $\mathbf{1 1 . 5}$ \\
\hline S.Ont case & $\mathbf{1 . 8 8}$ & $\mathbf{1 0 . 8}$ \\
\hline E.Ont case & $\mathbf{1 . 4 7}$ & $\mathbf{1 1 . 0}$ \\
\hline Gen.Ont gasoline from this LCA & $\mathbf{0 . 7 8}$ & -- \\
\hline
\end{tabular}

*Calculated from process energy sheet "I" cell J42 and J47

The use of the $\mathrm{r}_{\mathrm{E}}$ ratio clarifies a conceptual distinction that has been missing from the corn ethanol literature's preoccupation with the question of whether or not ethanol consumes more energy than it provides. This is the simple point that gasoline also consumes fossil fuel as it is used and made. The $\mathrm{r}_{\mathrm{E}}$ ratio for gasoline in table 6.10 is lower than even the most conservative assessment of corn-ethanol from Pimentel and Patzek (2005). All scenarios portrayed in the literature reviewed in this study find corn ethanol reduces fossil fuel use when the appropriate comparison is made.

\subsection{Discussion}

\subsubsection{Extent of fossil fuel and GHG emission reductions in regions of Ontario}

Biofuel use in Ontario and the global transport fuel sector is expanding into new locations and this research set out to establish the extent to which expected GHG and fossil fuel 
savings occur over in new production locations. In this study, E5 produced in the E.Ont case represents the new production area, and this fuel provided slight savings versus gasoline. The extent of the savings are less than that achieved in the S.Ont case, but neither case provides more than $1.3 \%$ reductions. Estimates for both regions suggest E5 provides a very modest contribution to climate change mitigation and substituting for fossil fuel use.

Although some environmental benefit of E5 use appears consistent between regions, this study has also found that some E5 blends in Ontario will have higher GHG emissions and higher fossil fuel consumption than some gasoline fuels. The reason for this is not due to higher burden from ethanol production activities, but instead due to multiple origins for the gasoline used in the province. Not surprisingly, the GHG intensity and fossil fuel consumption of E5 is closely tied to the gasoline portion of the product. Since heavier oil sand crude oil has double the greenhouse gas emissions compared to other forms of crude oil, E5 blended with gasoline from these sources is less favourable than some gasoline.

While this finding is important and could contradict the environmental promise of ethanol, it is also a scenario that only occurs in specific circumstances. Transport of E5 is currently limited to a couple hundred kilometers at most. Pure ethanol travels longer distances and the blending of ethanol into E5 occurs at fuel depots throughout the province. Therefore the use of E5 blended with gasoline from oil sand crude oil is restricted to areas of the province where oil sand derived gasoline is found in fuel depots. In other words, high GHG intensity E5 fuels will only be found in regions with high 
GHG intensity gasoline, and relative savings are still to be expected. At the same time since gasoline is refined from multiple types of crude oil in Southern Ontario, there are likely instances where a higher GHG intensity E5 fuel is used in place of a lower GHG intensity gasoline.

The gasoline supply systems in Ontario are more important to understanding transport fuel GHG emissions reduction opportunities than use of E5 in any of the cases reviewed here. Substituting conventional oil derived gasoline for oil sand derived gasoline would provide GHG savings that are more than double those from the use of E5 in the southern Ontario case. Reversing existing petroleum pipeline flow to bring offshore-derived petroleum to all of Ontario may appear politically naïve but the fact that Canada imports more than half of the crude oil used in the country while exporting more than $60 \%$ of domestic production (Rowan, 2006) makes such a suggestion more plausible.

There is some evidence that higher blends (E30 and E85) will become more common in Ontario. In these blends the importance of the characteristics of the gasoline in the final blend diminishes. This study finds that the environmental benefits of E85 blends in the case study regions differ sharply. An E85 blend made in the S.Ont case cuts emission by close to half, while the same blend in the east cuts emissions by only a third.

Thus some caution should be used if further expanding the ethanol industry into other parts of the province. This research has found that trucking southern Ontario corn to eastern Ontario ethanol plants would provide better GHG returns than using eastern corn. 
However it is clear that eastern Ontario farms will supply the eastern Ontario ethanol plant and given this fact, attention should turn to how to optimize biofuel production in all regions.

Some of the factors that led to higher emissions in the corn farming stage are physically constant, while others could be more easily changed to improve the ethanol production footprint. Physically constant structural limitations are: 1) corn yield which is limited by climate, regions with higher heat units have greater corn yield potential. Yield difference accounts for $18 \%$ of emissions in this study, and 2) grain drying where the removal of moisture requires minimum amounts of energy and greenhouse gases.

Two factors that are more easily altered by human agency are: 1) fertilizer rates nitrogen fertilizer alone accounts for half of emissions and was minimized in the S.Ont case by use of manure and GPS guided application based on soil sampling, and 2) field machinery intensity - farmers have the choice to farm corn with reduced need for tillage passes which can reduce GHG emissions by a small percentage. Adopting these practices involves a complex set of decisions that include financial resources for new equipment, and human and cultural capital to have the skills and desire to try new technology.

Finally, it is important to note that this study relied on the powerful LCA method but the nature of LCA limits the scope of recommendations. As Mitchell (2002, p. 176) puts it LCA finds the "best means to achieve ends which already have been chosen". In other words the desirability of using biofuel to support a car culture that currently consumes 35 
billion litres of gasoline nationally and contributes to the transport sector's $26 \%$ share of total GHG emissions (Env Canada, 2005) is not assessed. The structure of society and dependence on road transport is not within the scope of this LCA. This means that other valid reduction measures such as increased public transit or fuel economy standards have not been considered.

\subsubsection{On the need to consider regional differences in biofuel LCA}

Three reasons support an argument in favour of incorporating regional differences in biofuel LCA based on this study. First, is that the environmental benefits promised by biofuel diverge when viewed with provincial versus regional data. For E5, GHG and fossil fuel savings are so slight that in local production conditions have the potential to tip the balance from net GHG reductions to net GHG emissions. In this study, the source of crude oil used in the product has this effect. Furthermore, in fuel blends with higher proportion of biofuel, this study suggests that large differences exists in corn farming activities making some locations better suited for reducing GHGs. E85 in the S.Ont case

approximately halves GHG emission while the E.Ont case reduces emissions by only one third. Regional divergence between LCA results also occurs viewing data from other North American studies to the province of Ontario. This study found that previous North American LCA work underestimates fossil fuel savings potential of Ontario ethanol. In each of these examples it is only by examining more regionally refined data that these lessons have emerged. 
The second reason for incorporating regional differences is the nature of the production systems used to make biofuel. In the case of corn ethanol, thousands of farms each with unique characteristics provide raw material for the fuel. In this study 28 different activities were recorded for this stage, some were consistent between the case studies, some were not. The nature of farming with season long production cycles and unpredictable variables (e.g. climate, pests) provides a production system that is constantly in flux and location specific. This system is different than industrial systems with fixed and calibrated inputs for which LCA has historically been used and designed.

Third, taking regional differences into account develops insight into the paths towards environmental improvement of biofuel. One of the most powerful outcomes of LCA work is to identify points of possible improvement in a production system. Conducting large scale LCA involves the inevitable grouping of data that masks site specific circumstances. For example, the crude oil in the Gen.Ont case is a mix of $42 \%$ syncrude, $41 \%$ conventional, $16 \%$ bitumen and $1 \%$ heavy. This mix is not found in any actual physical gasoline batch that is produced in Ontario, instead it is contrived to best represent the various crude oil types used in the province. Grouping data in this manner is required to scale up the meaning of the LCA results and will allow for a sense of the size of greenhouse gas emissions that could be reduced by use of E5 in Ontario. However, in this instance, disaggregating the crude-oil data and identifying the sites where each type of crude oil is used would go a long way to pointing out the pathway to the least GHG intensive $\mathrm{E} 5$ fuel. 
Local or place based assessments direct researchers to the "unit process" level of information that is ideal for maximizing the benefits of LCA. This detail provides a powerful basis to identify practical opportunities to improve the environmental impact of biofuels. For example, an analysis of the best improvement opportunities that relied solely on the Gen.Ont case would focus on the activities that require the largest volumes of fossil fuels. Thus the ethanol manufacturing facility would be targeted over the farm field because the ethanol facility uses two times more fossil fuel than farm operations. However, armed with the results from the more refined regional S.Ont and E.Ont cases it is apparent that emissions are constant between the two ethanol manufacturing sites, but there is significant variation between the two in the corn farming stage tied to different farming practices. Comparing the reasons for difference in the locations then helps to identify the fossil fuel consuming activities that are most tractable (e.g., target tillage over grain drying)

One argument against the need to incorporate regional variation in biofuel LCA is that other LCA challenges are more fundamental and more important to address. For example, Reap et al (2008) in a general discussion of challenges facing LCA, rate the need to incorporate locally accurate inventory data as less important than LCA design problems such as establishing system boundaries and co-product allocation.

This study indicates however, that it is feasible to apply the standard ISO 14044 guidance to biofuel LCA which, in this study, led to consistency and transparency in controversial LCA design issues. For example, the E5 to gasoline comparison was strengthened by: 
selection of a functional unit that describes all six product systems that are compared; changes to original system boundary to remove emissions from production of farm and ethanol plant machinery to ensure fair comparison to the elements in the gasoline production boundary; and extension of the system boundary to include the "use" stage. Also, the series of checks recommended by ISO 14044 on the completeness of data and on sensitivity to changes in key input values led to the conclusion that the LCA results were robust when the uncertainty conferred by data availability and methodological choices was considered.

There are other biofuel LCA challenges. For example, the modelling of agricultural production systems introduces conceptual difficulties into biofuel LCA. Soil is a major input into corn production but the lack of a template for measuring soil impacts ultimately led to a decision to drop soil quality from the LCA. The reporting of results by production unit is also problematic in agricultural systems since production relies on sustaining and using a fixed land resource over a long period of time. As yield increases, production increases and LCA will report reduced environmental impact since inputs are spread out over a larger volume of "product". Short term yield gains may however come at the cost of long term productivity. A good example is the short term weed prevention that comes with moldboard plowing, but the yield gain achieved by less competition from weeds is offset by soil moisture loss and reduced soil quality in the longer term (Grandy et al 2006). An LCA cannot accommodate this long-term difference. 
The inability for LCA to incorporate data over long time spans is a function of the method which is based on inventory data from a specific time and place. This characteristic relates to the other major biofuel LCA challenge introduced earlier in section three, that of integrating related processes such as land use change or changes to food supply. These processes interact with biofuel production and will alter GHG emissions and thus are within the potential scope of the LCA. Incorporating the impacts of these processes requires monitoring, updating of LCA models every few years and better understanding the relationships between different human processes. This is an important challenge but is not an argument against incorporating regional differences in biofuel LCA. On the contrary, identifying the site specific production chains and locations of grain production could provide necessary information to understand process relationships and better model agricultural systems.

\subsubsection{A preliminary regional difference discussion in biofuel LCA}

The findings of this study emphasize the importance of regional differences in forming a reliable estimate of biofuel environmental performance. The potential error introduced by a large geographic scale focus in biofuel LCAs inventory data has received little attention, despite the interest policy makers have shown in the assumptions that influence biofuel LCA results. A recent report for NRCan from ChemInfo (2008) looked at sensitivity of LCA reports to differences in conversion efficiencies, land use and coproducts among other things but did not consider the scope of diverse data and results through space and time. 
It is puzzling why this shortcoming in biofuel LCAs has not received more attention in the literature. In the broader LCA literature, Reap et al (2008) have identified the problem of incorporating local uniqueness into LCA inventory data, but devote more attention to other challenges. The lack of greater attention is especially puzzling since the lack of spatial reality in the impacts suggested by LCA results has received such study (Potting and Hauschield, 2006, Reap et al 2008). For Potting (2005) the importance of deriving locally appropriate results is clear. She gives the example of calculating the environmental impacts of the life-cycle of linoleum production for which the pollutant toluene is emitted during manufacture and during use when it is lain on a floor. A typical LCA would sum up the total toluene emitted without consideration of the different exposure levels and populations in each life-cycle stage. The exposure of humans to the toluene is different in each case but the LCA results would not capture this difference.

Biofuel LCAs consider impact categories with effects on the global level (e.g., GHG emissions and fossil energy use) and thus have no need for locally specific impact modelling. In other words, GHGs are emitted to a global atmosphere with no difference between impacts of emissions that are from ethanol plant or farm or transport stages. Since impacts are on a large scale this might also explain the general use of aggregate inventory data from large regions.

Some efforts have been made to reduce impact of data variability using Monte Carlo statistics. Groode and Haywood (2007) developed a probability range for several data points instead of single values and report GHG emissions for corn ethanol production for 
two US States. However the standard deviations of the resulting values are large and overlap between the two results. In other words, there was little statistical basis to claim a difference between the range of values reported for each State, and thus it appears more refined regional or place-based study needs to be employed to efforts to deal with data variability.

This research is an initial contribution to building up the spatial rigour of biofuel LCA assessments. It has indicated when local data will provide meaningful improvements in the accuracy of results and has shown what points in the E blend life cycle to focus in on.

\subsubsection{Scale matters - bringing geography into the discussion}

The question of appropriate scales for analysis has long been a focus of geography, and geographers look to find the right scale of analysis for the scale of the phenomena (Montello, 2001).

Production of biofuel is most often promoted at a national or provincial scale. The introduction to this thesis showed that nations make decisions to promote bioenergy mainly to encourage fossil fuel and greenhouse gas reductions. These are national or provincial scale interests and it is therefore no surprise that assessments of these impacts have been historically used data from this large scale.

Many of the production stages of biofuel take place at a local scale. In particular, the materials that are converted to the fuel are linked to specific locations. In the case of ethanol corn from hundreds of separate locations are converted to the end fuel product. 
This research project has developed data units more appropriate to the scale of the production phenomena and used the same analytical tool (LCA) that has been used at the larger provincial scale.

Being able to compare the results of analysis using averaged provincial data to results for disaggregated local data has helped identified the appropriate scales of analysis for this particular phenomena. Provincial scale LCA assessments of E5 fuel appear sufficient to capture intra-provincial differences in E5 vs. gasoline comparisons. However those interested in improving the environmental performance of E5 blends will benefit from local scale data. Furthermore, at higher blends local differences in corn farming require integration of a limited scope of local data into the assessment.

In the end the greatest value of the LCA tool may be as a heuristic or learning tool, forcing the researcher to define and account for a life cycle of a product and dig into the origins of data. This provides a good way of thinking about the phenomena of using biofuels to reduce environmental impacts. The LCA way of thinking helps us compare gasoline and biofuel on the same basis and in this sense, closer to the reality of the biofuel option.

Graham (2005) writes that recognizing spatial differentiation in the theoretical meaning of results is akin to rejecting the universal expectation of scientific law. This is one more reason why claims of greenhouse gas savings from biofuel LCAs might benefit with a subscript "results vary." 


\section{Summary}

Policy makers in Ontario and throughout the world encourage biofuels as a greenhouse gas reduction measure and energy alternative. Increased biofuel production, timed with fluctuations in energy and cereal prices have sparked questions about the impact of biofuel on other production systems, social impacts, net environmental effects and the need for improved accuracy in accounts of "life cycle" greenhouse and fossil fuel reduction potential.

The production of biofuel occurs over many stages and requires inputs from diverse locations. To date, assessments of the life cycle energy and greenhouse gas costs of producing fossil fuels and biofuel alternatives have largely been oblivious to diversity in local production conditions.

This study employed the life cycle assessment method to assess fossil fuel use and greenhouse gas emissions for E5 fuel and gasoline in Ontario (Canada). Southern Ontario and eastern Ontario regional case studies were compared to assess the extent to which regional variations might alter the potential for biofuels to reduce GHG emissions and fossil fuel consumption. This study also compares these more detailed regional studies to a more generalized provincial case study in order to gauge the value of conducting place based research compared to "reconnaissance" level studies. Overall, this research provides preliminary evidence on the need to incorporate regional variation in biofuel LCA and information on a path towards optimizing biofuel production in diverse locations. 


\subsection{Reviewing the Objectives}

The thesis set out to meet two objectives:

Objective 1: To compare fossil fuel requirements and greenhouse gas emissions for E5 and gasoline fuel production in two regions in Ontario using life-cycle assessment.

Outcome: The general steps of E5 and gasoline production (life cycle stages) were identified in section two. This information coupled with a review of past biofuel LCA studies (section three) set the foundation for the design of the LCA which closely followed the established ISO 14044 guiding framework for LCA (section five). Two regional case studies (S.Ont and E.Ont) and a provincial general case (Gen.Ont) were developed from interviews with producers and from existing data sets (section four). These provided the inventory data for the life cycle assessments of E5 and gasoline. Based on the case study results, region to region comparisons of estimate of fossil fuel consumption and greenhouse gas emissions were presented and analyzed for each stage of production and for the total life cycle in the results section six.

Objective 2: To assess the need for LCA to capture regional differences associated with E5 production.

Outcome: Based on the case study results, two approaches were taken to assess the need to incorporate regional variation in biofuel LCA. First, a region to region comparison indicated the extent to which outcomes differ by region (section 6) and allows for 
judgment on this basis. Second, the information provided by the provincial case study was compared to that provided by the more refined regional case studies (section 6), allowing for judgment of the value of place based LCA, in particular for optimizing biofuel GHG and fossil fuel reduction potential (section $6.5,6.6$ ).

\subsection{Major Findings}

\section{(1) Place matters \#1: Place of corn production alters ethanol fuel characteristics.}

Corn farming is a highly variable process requiring fuels for machinery, direct inputs to the field and energy to dry grain. Regional variation in inherent physical potential for growing corn and a regional component in dominant farm management practices alter the fossil fuel consumption and GHG emissions associated with grain corn production for ethanol fuels in Ontario.

The E.Ont case represents a region that has a colder climate with lower corn yield than southern Ontario (8.9 tonnes / ha vs. 10.1 tonnes / ha) and relatively low adoption of conservation tillage (19\% of crop area of vs. $44 \%$ ). These regional differences together with differences in rates of fertilization contribute to an estimated $60 \%$ fewer GHG emissions and $80 \%$ fewer fossil energy consumed in the S.Ont case compared to the E.Ont case. This difference is substantial enough to suggest that (from a GHG and fossil fuel use perspective only) it is justified to truck corn from southern Ontario to eastern Ontario ethanol plants when making E5 fuel. 
Regional differences were not seen for all production processes. Most conversion of corn to ethanol in both southern and eastern Ontario occurs in ethanol plants using the same "dry-mill" process, and designed on a similar technical layout suggesting consistent emissions and fossil fuel use for this stage of E5 production across the province.

\section{(2) Place matters \#2: E5 production regions combines local and external inputs}

E5 fuel inputs include products from the local region as well as products from beyond the region. Both types of inputs must be captured in E5 LCA and it is not appropriate to focus solely on the local region when conducting the more refined regional assessments such as those attempted in this study. The "place" where E5 is produced is a combination of multiple locations of all E5 inputs, some are separated by less than a couple of hundred kilometers (e.g. production of corn compared to the ethanol plant) but others are separated from 1000s of kilometres (e.g., crude oil source compared to gasoline refinery).

In this study the external inputs are highly important to the study outcomes. The Province of Ontario shows a split in gasoline supply origins. The S.Ont E5 case uses gasoline derived from synthetic crude oil from Western Canada (increasingly typical for the region). The E.Ont case, which uses gasoline derived from offshore oil from the North Sea (predominant source for the region) has four times less fossil fuel use and two times less greenhouse gas emissions for the crude oil extraction stage. This contribution is enough to push fossil fuel consumption and GHG emissions for S.Ont E5 higher than those of E.Ont E5. 


\section{(3) Optimizing E blend potential requires sub-provincial assessments}

Province wide studies are adequate for "reconnaissance" level assessments but not sufficient for optimizing reductions in fossil fuel consumption and GHG emissions.

An important first question when considering use of $\mathrm{E}$ blend fuels in Ontario is to estimate if the biofuel will provide any GHG and fossil fuel reductions. In this respect the findings of the provincial case study and both regional case studies agree. In each case, life cycle greenhouse gas emissions and fossil fuel use for E5 were estimated to be slightly lower than that of gasoline (savings are range from $0.7 \%$ to $1.3 \%$ ). This indicates that a generic province wide assessment is adequate to answer this first question, and there is little additional value to distinguishing reductions by region. Furthermore, the generic provincial estimate provides a level of information useful enough to observe that fossil energy requirements for Ontario ethanol production are lower that that reported in the North American corn-ethanol literature.

However, when considering exactly where and how to invest in E5, more information is required. Sub-provincial regional assessments help delineate the processes that provide greatest return. This study suggests that it is the southern Ontario region that will provide the greatest return due to relatively low GHG emissions from corn-ethanol production and relatively high GHG emissions from gasoline production. Crude oil extraction is the most important process in this region. For example, this research estimates that substituting conventional crude oil in place of synthetic crude derived gasoline in the S.Ont case would provide four times more GHG reductions than that provided by E5. The 
presence of conventional oil, synthetic crude oil and bitumen in the gasoline refineries of this region also introduces the possibility that some E5 fuels will have higher fossil fuel use and GHG emissions than some pure gasoline fuels if the gasoline portion of each product is derived from different forms of crude oil. In eastern Ontario, efforts to alter farm management practices are potentially more rewarding. No- till farming which reduces overall machinery fuel use is not as extensively practiced in eastern Ontario as in the south, and could be targeted.

Shifting the focus to more refined regional studies also offers the opportunity for closer examination of the interactions that contribute to environmental impacts of E5 production. For example, the S.Ont case study farm minimized quantities of fertilizer use by applying manure, regular soil tests, and global positioning system guided application. By studying the particular place where corn was produced, a suite of potential farm management practices was identified that could minimize fossil fuel consumption and GHG emissions in corn-farming across the province.

Finally, the main reason why a provincial scale assessment is adequate to estimate Ontario E5 fossil fuel and GHG benefits is the nature of the E5 blend. Gasoline is $95 \%$ of the product and when burned contributes a overwhelming constant portion of total emissions and fossil fuel consumption. In higher ethanol-blends, however, the constant contribution from gasoline use is reduced, and the relative contribution from other regionally divergent life cycle stage contributions increases. This study indicates that for 
higher (E85) blends, sub-provincial and place based assessments are particularly important to optimize biofuel potential.

\section{3_Advancing the research}

This research is a part of the larger challenge of evaluating biofuels as an alternative energy source and as a greenhouse gas mitigation measure. It has provided preliminary information on the need for regional accuracy in biofuel LCA work and on optimizing biofuel production but could be improved in this context by a focus on :

- Extending the research to longer term scenarios. Wider application of biofuels to transport will likely involve greater use of flex fuel vehicles and more use of nongrain feedstocks to make gasoline substitutes. The degree to which optimal locations for production change as these parameters change is worth study.

- Measuring the need to incorporate regional variation in biofuel LCA alongside other challenges that decrease the accuracy of the LCA tool. Transparency in LCA design choices, improving applicability to agricultural systems and integrating GHG emissions from associated land use conversions are all major issues in the use of LCA for biofuels. Meeting these challenges will likely require updating LCA models every few years and expanding the boundary of processes that are considered in the model. Place-based biofuel LCA has a role to play in helping to identify interactions that are relevant to these challenges such as factors in farm level decisions to plant corn, but research into other new forms of biofuel LCA is needed. 
- The best locations for farming corn with lower GHG emissions and fossil fuel use could be mapped with data from main contributing activites in the farming stage identified in project such as fertilizer use, grain drying, combine fuel use, and planter fuel use. Coarse level data is available from agricultural census data. Such data includes fuel use, yields and money spent on farm inputs that would need to be resolved to the level of farm inputs for corn

- Incorporate modelling advances in spatial resolution on important data points such as $\mathrm{N}_{2} \mathrm{O}$ emission rates from soil.

Finally, the strategy to pursue GHG reductions by use of $\mathrm{E} 5$ blends is estimated to provide only slight savings over gasoline use. The biofuel option must be considered alongside other alternatives to meet the goal of energy reduction and climate change mitigation from the transport sector. A number of research topics are relevant:

- Assess biofuel tradeoffs through study of the economic implications of a new market for grains on food supply, particularly in food insecure regions and households and recommend development of policy options for minimizing vulnerability.

- Consider the non-biofuel options for achieving the same goals. These include regulated vehicle fuel economy, improving public transit infrastructure and carbon taxes. The benefits and tradeoffs associated with these options to reduce fossil energy 
use and GHG emissions could be measured alongside spatially sensitive biofuel options.

- The impact of biofuel development on rural development and farmer engagement with climate change mitigation options is compelling. The rise of ethanol has lead to the rise of a new supply chain with incentives for farming communities to diversify and become owners of the production and distribution system of their products. The differences between this supply chain and the conventional food chain in terms of ownership, power relations, and place in the historical trend of agriculture in Ontario and around the world is of interest.

Overall this research has extended the understanding of the potential for biofuels generally, and for E5 fuels specifically, to address societal concerns regarding climate change mitigation and alternatives to fossil fuel use. This thesis suggests that E5 fuels will have at best a modest role in mitigating climate change and substituting for fossil fuel resources. Optimizing the potential for transportation ethanol biofuels to reduce fossil fuel use and GHG emissions requires: understanding of regional factors (e.g. corn yield): of factors external to the region (e.g. source of crude oil); and of the ethanol blend level. Finally, although the application of LCA to biofuel faces challenges, LCA provides a powerful framework to capture not only the long production chain of the commodity but also regional dimensions within the biofuel production chain 


\section{References}

Agriculture Canada, 2008. Soil Landscapes of Canada v 3.0. Agriculture Canada National Land and Water Information Service. Available at http://nlwissnite1.agr.gc.ca/slc-ppc30/index.phtml Accessed October 7, 2008

Armstrong, M. 2008. personal communication with Melissa Armstrong, January 2008, Communications co-ordinator for Greenfield Ethanol Inc.

Boustead and Hancock. 1979. Handbook of industrial energy analysis. Ellis Horwood. Rexdale, Ontario. 410 pgs.

CAPP, 2006. Canadian Association of Petroleum Producers. CAPP Reserves December 31, 2006. Available at http:/www.capp.ca/raw.asp? $\mathrm{x}=1 \& \mathrm{dt}=\mathrm{DPI} \& \mathrm{dn}=128778$ Accessed April 8, 2008

CAPP, 2004. A national inventory of Greenhouse Gas (GHG), Criteria Air Contaminant (CAC) and Hydrogen Sulfide (H2S) Emissions by the Upstream Oil and Gas Industry. Volume 1. Overview of the GHG Inventory. Canadian Association of Petroleum Producers. 248 pgs

CFRA, 2008. Canadian Renewable Fuels Association Canadian Ethanol Production List. Available at http://greenfuels.org/lists.php\#ethProd accessed October, 2008

California Energy Commission, 1999. Evaluation of biomass-to-ethanol fuel potential in California. 405 pgs

Canals M., Burnip G.M., and S.J. Cowell. 2006. Evaluation of the environmental impacts of apple production using Life Cycle Assessment (LCA): Case study in New Zealand. Agriculture, Ecosystems and Environment. Vol. 114 pp 226-38.

Chambers R.S., Herendeen R.A., Joyce J.J. and Penner P.S. Gasohol: Does it or Doesn't it Produce Positive Net Energy. Science 1979 Vol 206. No. 4420. 789-95.

Cheminfo. 2008. Sensitivity Analysis of Bioethanol LCA Models to Determine Assumptions with the Greatest Influence on Results. 173 pgs

Chevron, 2007. Motor Gas technical review. Chapter 3. Gasoline refining and testing. Available at http://www.chevron.com/products/prodserv/fuels/bulletin/motorgas/downloads Accessed December 2007

Clark, I. 2008. Personal communication, Ian Clark, QA/QC Manager for Suncor St. Clair ethanol plant. April 2008 
Curran, M.A. 2007.Co-product and input allocation approaches for creating life cycle inventory data: a literature review. Int Journal of Life Cycle Assessment 1:65-78, Special Issue

Curran. M.A., 1996. Chapter 1 The History of LCA. in Environmental Life Cycle Assessment. McGraw-Hill. New York.

Deluchhi 2004. Conceptual and methodological issues in lifecycle analysis of transportation fuels. Publication No, UCD-ITS-RR-04-45. Institute of Transport Studies. University of Californa Davis. 22 pgs

Delucchi, 2002. Overview of the life cycle emissions model. Publication No. UCD-ITSRR-02-02. Institute of Transport Studies. University of California Davis. 11 pgs

Dias De Oliveira, Marcelo E.; Vaughan, Burton E.; Rykiel, Edward J. 2005. Ethanol as Fuel: Energy, Carbon Dioxide Balances, and Ecological Footprint. BioScience, Volume 55, Number 7, July. 593-602.

EIA, 2008a. Energy Information Administration (United States). Crude Oil Production. Available at http://www.eia.doe.gov/neic/infosheets/crudeproduction.html. October, 2008

EIA, 2008b. Energy Information Administration (United States). Frequently Asked Questions. http://tonto.eia.doe.gov/ask/crudeoil_faqs.asp accessed October, 2008

EU June 2008. "EU Biofuels Policy" Speech by Commissioner Fischer Boel. European Commission reference no. SP08-131EN

Enbridge, 2002. Enbridge pipeline system. Available at http://www.enbridge.com/pipelines/about/ Accessed October 7, 2008

Environment Canada, 2008. Climate Data online. Precipitation search for Sarnia and for Ottawa. http://www.climate.weatheroffice.ec.gc.ca/climateData/canada_e.html Accessed October 7, 2008

Environment Canada, 2007. National Inventory Report, 1990-2005. Greenhouse gas sources and sinks in Canada. Table 8.

http://www.ec.gc.ca/pdb/ghg/inventory_report/2005_report/ta8_2_eng.cfm Accessed October 7, 2008

Environment Canada. 2006. National Inventory Report, 1990 - 2004. Greenhouse gas sources and sinks. Table A4.2 Reference approach conversion factors for Canada. Available at http://www.ec.gc.ca/pdb/ghg/inventory_report/2004_report/ta4_2_e.cfm Accessed October 7, 2008 
FAO Conference, 2008. High level conference on world food security: the challenges of climate change and bioenergy. HLC/08/REP. Food and Agricultural Organization of the United Nations. June 2008. 51 pgs

FAO 2007. A Review of the Current State of BioEnergy Development in G8 + 5 countries. Global Bioenergy Partnership of tbe Food and Agricultural Organization. 292 pages

Fargione J., Hill J., Tilman D., Polasky S and P. Hawthorne. 2008. Land Clearing and the Biofuel Carbon Debt. Science vol 319. 29 Feb 2008 p 1235-8

Farrell A.E., Plevin R.J., Turner B.T.m Jones A.D., O'Hare M and Kammen D.M. 2006. Ethanol Can Contribute to Energy and Environmental Goals. Science 311. 506-08.

Hendrickson C., Lave, L., and Matthews H.S. 2006. pages 3 to 12 of Chapter 1 Exploring Environmental Impacts and Sustainability through Life Cycle Assessment in Environmental Life Cycle Assessment of Goods and Services: An Input - Output Approach. RFF Press. Washington

G8 Statement, July 2008. G8 Leaders Statement on Global Food Security. Available at http://www.g8summit.go.jp/eng/doc/doc080709_04_en.html Accessed October 3 ${ }^{\text {rd }}, 2008$

GHGenius 2007. A model for lifecycle assessment of transportation fuels. Model version 3.11 downloadable at www.ghgenius.ca

GHGenius 2007b. 2007 Crude oil production update for GHGenius. Prepared for Natural Resources Canada by S\&T squared consultants. 25 pgs

GHGenius 2006. Expansion of GHGenius to include sequestering carbon from energy production pathways. Prepared for Natural Resources Canada. S\&T squared consultants. 63 pgs

GHGenius 2005. Documentation for Natural Resources Canada's GHGenius Model 3.0. Prepared for Natural Resources Canada. S\&T squared consultants. 541 pgs.

GREET, 2007. Greenhouse gases, Regulated Emissions, and Energy use in Transportation (GREET) model. Version 2.7. Argonnne National Laboratory. Available at http://www.transportation.anl.gov/modeling_simulation/GREET/

Govt. Alberta. Undated a. The Basics of Bitumen. Oil Sands Discovery Centre. Fact Sheet .2 pgs Available at http://www.oilsandsdiscovery.com/oil_sands_story/facts.html Accessed October, 2008

Govt. Alberta. Undated b. Surface mining extraction. Oil Sands Discovery Centre. Fact Sheet. 2 pgs Available at http://www.oilsandsdiscovery.com/oil_sands_story/facts.html Accessed October, 2008 
Govt. Alberta. Undated c. Upgrading. Oil Sands Discovery Centre. Fact Sheet. 2 pgs Available at http://www.oilsandsdiscovery.com/oil_sands_story/facts.html Accessed October, 2008

Govt. Ontario, 2005. Press release. McGuinty Government Takes Next Step on Cleaner Air. Ethanol Growth Fund Now Accepting Applications; Five Per Cent Standard Takes Effect January 1, 2007.

Govt. Ontario, 2008. Province investing in Ontario's ethanol producers. Ethanol growth fund opens new round of applications. Press release. Original release July 6, 2007 updated August 2008

Govt. Ontario, 2008b. Ethanol blend gasoline: FAQ. 3 pgs downloaded from www.ene.gov.on.ca/envision/ethanol/ December 15, 2008

Graboski, M. 2002. Fossil energy use in the manufacture of corn ethanol. (National Corn Growers Association, Washington, DC, 2002). Also available at http://www.ncga.com/ethanol/pdfs/energy_balance_report_final_R1.PDF

Grandy, A.S., Robertson G.P. and K.D. Thelen. 2006. Do Productivity and Environmental Trade-offs Justify Periodically Cultivating No-till Cropping Systems? Agronomy Journal. Vol. 98 pgs 1377-83

Graham E. 2005. Philosophies underlying human geography research in Methods in Human Geography: a guide for students doing research projects ed R Flowerdew and D. Martin. Longman

Goddard T.W., Kryzanowski L.M. and H. Purveen. 2006. Soil Science Society of America Journal. Volume 70. Pgs 235-248

Greenfield, 2008. Personal communication with Greenfield representative Melissa Armstrong. October 3, 2008

Groode, T. and J.B. Heywood. 2007. Ethanol: A look ahead. Publication no. LFEE 2007002 RP. Laboratory for Energy and Environment. Massachusetts Institute of Technology. $25 \mathrm{pgs}$

Guinee, Jeroen B., Handbook on Life Cycle Assessment; Operational Guide to the ISO Standards 2004

Hammerschlag R. 2006. Ethanol's Return on Investment: A Survey of the Literature 1990 - Present. Environmental Science and Technology. 40. 1744-50.

Hansard, May 2008. House of Commons Debate. Vol 142. Number $992^{\text {nd }}$ session $39^{\text {th }}$ parliament 
Hayashi K., Gaillard G. and T. Nemecek. 2005. Life cycle assessment of agricultural production systems: current issues and future perspective. Book chapter pgs 98-110. Food and Fertilizer Technology Centre for the Asia and Pacific Region.

Hendrickson C., Lave, L., and Matthews H.S. 2006. pages 3 to 12 of Chapter 1 Exploring Environmental Impacts and Sustainability through Life Cycle Assessment in Environmental Life Cycle Assessment of Goods and Services: An Input - Output Approach. RFF Press. Washington. 262 pgs

Hill J., Nelson E., Tilman D., Polasky S. and D. Tiffany. 2006. Environmental, economic and energetic costs and benefits of biodiesel and ethanol biofuels. Proceedings of the National Academy of Science. Vol 103 no. 30 pgs 11206-11210

Hood C.F., and G. Kidder. 1992. Fertilizers and Energy. Fact sheet EES-58. University of Florida extension service. 4 pgs.

ICM, 2008. ICM performance guarantee. www.icminc.com. Accessed June, 2008

IEA, 2007. Potential contribution of bioenergy to the world's future energy demand. IEA Bioenerg. 12 pgs

IEA, 2004. World Energy Outlook. 2004. International Energy Agency. Paris. 577 pgs

IPCC, 2007a. Climate Change 2007: Synthesis Report. Summary for Policymakers. An assessment of the Intergovernmental Panel on Climate Change. 22pgs

IPCC, 2007b: Summary for Policymakers. In: Climate Change 2007: Impacts, Adaptation and Vulnerability. Contribution of Working Group II to the Fourth Assessment Report of the Intergovernmental Panel on ClimaCte Change, M.L. Parry, O.F. Canziani, J.P. Palutikof, P.J. van der Linden and C.E. Hanson, Eds., Cambridge University Press, Cambridge, UK, 7-22.

IPCC. 1995. Summary for Policymakers:Scientific-Technical Analyses of Impacts, Adaptations and Mitigation of Climate Change - IPCC Working Group II. 15 pgs

ISO 2006a. Environmental Management - Life cycle assessment - Principles and Framework. International Standard ISO 14040:2006 (E) second edition. International Organization for Standardization. Geneva. 20pgs

ISO 2006b. Environmental Management -Life cycle assessment - Requirements and guidelines. International Standard ISO 14044:2006 (E) second edition. International Organization for Standardization. Geneva. 46 pgs.

Note: Permission to use extracts from ISO 14040:06 and ISO 14044:06 was provided by Standards Council of Canada, in cooperation with IHS Canada. No 


\section{further reproduction is permitted without prior written approval from Standards}

Council of Canada.

Ilbery B. and D. Maye. 2005. Alternative (shorter) food supply chains and specialist livestock products in the Scottish-English borders. Environment and Planning A. vol. 37. Pgs 823-44

Johnson M.A., 1983. On Gasohol and Energy Analysis. Energy. volume 8. No. 3. P 22433

Kim S. and B. Dale. 2006. Ethanol Fuels: E10 or E85 - Life Cycle Perspectives. International Journal of Life cycle assessment. Vol 11. No.2 pgs 117-21

Kim S. and B Dale. 2005. Life cycle assessment of various cropping systems utilized for producing biofuels: Bioethanol and biodiesel. Biomass and Bioenergy 29. 2005. 426-439

Kim S. and B. Dale, 2004. Cumulative Energy and Global Warming Impact from the Production of Biomass for Biobased Products. Journal of Industrial Ecology. Volume 7. No. 3-4 pgs $147-162$

Kim S. and Dale B. 2002. Allocation Procedure in Ethanol Production System from Corn Grain. International Journal of Life Cycle Assessment. 7 (4)237-44

Klopffer W. 2006. The role of SETAC in the development of LCA. The International Journal of Life Cycle Assessment. Volume 11 LCA Special (1) 2006. Pgs 116-22

Labellle, 2008. Personal communication. Marcel Labelle, Wholesale Sales Manager. MacEwan Petroleum Inc. November 2008

Larson E.D. 2006. A review of life-cycle analysis studies on liquid biofuel systems for the transport sector. Energy for Sustainable Development. Volume X no.2. pgs 109-126

Levelton Engineering Ltd., and S\&T Squared Consulting Inc. 2000. Assessment of net emissions of greenhouse gases from ethanol-gasoline blends in southern Ontario. Prepared for Agriculture and Agri-Food Canada

Lorenz, D.; Morris, D. 1995. How Much Energy Does It Take to Make a Gallon of Ethanol?; Institute for Local Self-Reliance: Washington, DC. available at http://www.carbohydrateeconomy.org/library/admin/uploadedfiles/How_Much_Energy_ Does_it_Take_to_Make_a_Gallon_.html

Maclean H.L, Lave L.B., Lankey R. and S. Joshi. A Life-Cycle Comparison of Alternative Fuels. Journal of Air and Waste Management Association. Vol 50. Pgs 17691779 
Marland, G.; Turhollow, A. F. 1991. CO2 emissions from the production and combustion of fuel ethanol from corn. Energy 1991, 16 (11/12), 1307-1316.

Malca and Friere. Renewability and life-cycle energy efficiency of bioethanol and bio-ethyl tertiary butyl ether (bioETBE): Assessing the implications of allocation. Energy 31 (2006) 3362-3380

Marris E. 2006. Drink the best and drive the rest. Business Feature. Nature. vol 444.7 December 2006. Pgs 670-2

McKillop, M. 2008. Personal communication with Matt McKillop, Broker for London Agricultural Commodities. April 2008

Mitchell B. 2002. Resource and Environmental Management. $2^{\text {nd }}$ edition. Prentice-Hall. 367 pgs

Montello, D.R. Scale in Geography in International Encyclopedia of the Social and Behavioural Sciences. Pgs 13501-4.

NEB, 2006. Canada's Oil Sands. Opportunities and Challenges to 2015: An update. National Energy Board. Cat. No. NE23-116/2006E. ISBN 0-662-43353-X 85 pgs

NPRI, 2007. National Pollution Release Inventory. Online data search of 2007 data for Ontario gasoline terminals. http://www.ec.gc.ca/pdb/querysite/query_e.cfm Accessed September, 2008

National ethanol vehicle coalition, 2008. E85 refuelling location search. http://www.e85refueling.com/ Accessed October 6, 2008

New Zealand Govt. 2008. Legislation passes to enable sustainable biofuels. http://www.beehive.govt.nz/release/legislation+passes+enable+sustainable+biofuels $\% 20$ Accessed October 2008

NRCan 2005. Overview of the Canadian downstream petroleum industry. Oil division. 26 pgs.

NRCan 2003. S\&T Squared Consultants Inc. The addition of ethanol from wheat to GHGenius. Prepared for: Natural Resources Canada - Office of Energy Efficiency. 30 pgs.

O'Connor, D. GHGenius developer and manager. Personal communication, September 3, 2008

Odell P.R. 2004. "Energy." The Social Science Encyclopedia. Third edition. Ed. Adam Kuper and Jessica Kuper . Routledge, 2004. Routledge Reference Resources online. Taylor \& Francis Publishing Group. 
OMAFRA, 2007a. Grain Corn. Area and Production by County. 2007Ontario Ministry of Food and Rural Affairs.

http://www.omafra.gov.on.ca/english/stats/crops/ctygrcorn07.htm Accessed October, 2008

OMAFRA, 2007b. County profiles. Available at http://www.omafra.gov.on.ca/english/stats/county/index.html Last accessed October 7, 2008

Patzek, T. 2006. A Statistical Analysis of the Theoretical Yield of Ethanol from Corn Starch. Natural Resources Research. vol. 15 no.3 pgs 205-212

Patzek, T. 2004. Thermodynamics of the Corn-Ethanol Biofuel Cycle. Critical Reviews in Plant Sciences, 23(6):519-567.

Pimentel D. 2003. Ethanol Fuels: Energy Balance, Economics, and Environmental Impacts are Negative. Natural Resources Research. Vol 127-133.

Pimentel D and Patzek T. 2005. Ethanol Production Using Corn, Switchgrass, and Wood; Biodiesel Production Using Soybean and Sunflower. Natural Resources Research. Natural Resources Research, Vol. 14, No. 1.p 65

Potting J. 2005. Spatial differentiation in life cycle assessment; a framework, and sitedependent factors to assess acidification and human exposure. $\mathrm{PhD}$ thesis. Utrecht University

Potting J and Hauschild, 2006. Spatial Differentiation in Life Cycle Impact Assessment A decade of method development to increase the environmental realism of LCIA. 11. ? International Journal of Life Cycle Assessment. Special Issue. p 11-13

REAP, 2008. Analysing Ontario Biofuel Options: Greenhouse Gas Mitigation Efficiency and and Costs. Final report prepared by Resource Efficient Agricultural Production (REAP) for BioCap Foundation. 42 pgs

Randall, B. 2008. Peak Oil Production and Energy Conservation. Lecture at Carleton University January 16,2008

Rau M. 2008. Personal communication August 19, 2008

Reap J.., Roman F., Duncan., S and B. Bras. 2008. A survey of unresolved problems in life cycle assessment. Part 1: goal and scope and inventory analysis. International Journal of Life Cycle Assessment. Vol. 13. No 4. Pgs 374-88 
Rebitzer G., Ekvall T., Frischknecht R., Hunkeler D., Norris G., Rydberg T., Schmidt WP., Suh S., Weidema B.P. and D.W. Pennington. Life Cycle Assessment. Part 1:

Framework, goal and scope definition, inventory analysis, and applications. Environment International. Vol 30. Pgs 701-20

Renewable Fuels Association, 2008. Ethanol Facts: Engine Performance. http://www.ethanolrfa.org/resource/facts/engine/ Accessed October, 2008

Rowat M. 2006. Boom Times: Canada's Crude Petroleum Industry. Statistics Canada analytical paper. Catalogue no. 11-621-MIE - No. 047. 13 pgs.

Rowe R., Whitaker J., Chapman J., Howard D., and G. Taylor. Life cycle assessment in the bioenergy sector: Developing a systematic review. Working paper. UK Energy Research Centre. UKERC/WP/FSE/2008/002

Royal Society 2008. Sustainable Biofuels: Prospects and Challenges. RS. Policy Document 01/2008. 90 pgs

STDC 2006. Sustainable Development and Technology Canada. Renewable Fuels Biofuels. SD Business case 2006. version 1.0.

Smith, C.E. 2008. Ethanol pipelines. Oil and Gas Journal. Feb 18, 2008

Searchinger T., Heimlich R., Houghton R., Dong F., Elobeid A., Fabiosa J., Tokgoz S., Hayes D and T Yu. 2008. Use of U.S. Croplands for Biofuels Increases Greenhouse Gases Through Emissions from Land-use change. Science vol 319. 29 February 2008. $1238-40$

Shapouri, H, McAloon A. 2004. "The 2001 net energy balance of corn ethanol" (U.S. Department of Agriculture, Washington, DC, 2004). Available at http://www.usda.gov/oce/reports/energy/net_energy_balance.pdf

Shell, 1983. The petroleum handbook compiled by staff of the Royal Dutch/Shell Group of Companies. $6^{\text {th }}$ edition. Amsterdam. 710 pgs

Simpson R.D., Toman M.A and R. Ayres. 2005. Introduction: The "New Scarcity". in Scarcity and Growth Revisited ed. R Simpson, M Toman and A Ayers. RFF Press. 2005

Smeets E., Junginger M., Faaij A., Walter A. and P. Dolzan. Sustainability of Brazilian ethanol. Report NWS-E-2006-110. University of Utrecht. Commissioned by the Netherlands Agency for Sustainable Development and Innovation. 136 pgs

Statistics Canada, 2008a The Supply and Disposition of Refined Petroleum Products. Catalogue no. 45-004-X. 90 pgs 
Statistics Canada, 2008b. March $31^{\text {st }}$ intentions 2008. Principle field crop reporting series. Catalogue no. 22-002-X

Statistics Canada, 2007b. Canadian vehicle survey. Annual 2007. Catalogue no. 53-223$\mathrm{X}$

Statistics Canada, 2007. March Intentions of Principle Field Crop Areas, Canada 2007. Field Crop reporting series number 2. Catalogue No. 22-002-XIB, Vol. 86, No. 2

Statistics Canada, 2006a. March Intentions of Principle Field Crop Areas, Canada 2006. Field Crop reporting series number 2. Catalogue No. 22-002-XIB, Vol. 85, No. 2

Statistics Canada, 2006b. 2006 Census data. Community Profiles. http://www12.statcan.ca/english/census06/data/profiles/community/Index.cfm?Lang=E Accessed October 7, 2008

Statistics Canada, 2001. 2001 Census of Agriculture. Agricultural Community Profiles. http://www25.statcan.ca:8081/AgrProfile/acphome.jsp Accessed October 7, 2008

Syncrude corporation. 2006. Syncrude Sustainability Report. Syncrude Canada Ltd. 60 pgs

Szklo A., Schaeffer R. and F. Delgado. 2007. Can one say ethanol is a real threat to gasoline? Energy Policy 35 5411-5421

Trenkle A. 2003. Evaluating wet and dry distillers grain soluables for finishing Holstein steers. Report to Iowa Corn Promotion Board. Iowa State University.19pgs

Vandergaast G., 1999. Opportunities for Reducing Greenhouse Gas Emissions by Using Ethanol Based Fuels: A Case Study of the Potential for Grain Corn Production. M.A. Thesis. Carleton University. 213 pages

von Blottnitz H., and M. Curran. 2007. A review of assessments conducted on bioethanol from a net-energy, greenhouse gas and environmental life cycle perspective. Journal of Cleaner Production. Vol 15. Pgs 607-19

WRI. 2007. Biofuels for Transport - Global Potential and Implications for Sustainable Energy and Agriculture. Worldwatch Institute. Earthscan. London. 452 pgs.

Wang M., Lee H., and J. Molbourg. 2004. Allocation of Energy Use in Petroleum Refineries to Petroleum Products Implications for Life-Cycle Energy Use and Emission Inventory of Petroleum Transportation Fuels. International Journal of Life Cycle Assessment. Vol 9. No.1 pgs 34-44

Wang, M. 2002. "Development and use of GREET 1.6 fuel-cycle model for transportation fuels and vehicle technologies"'(Tech. Rep. ANL/ESD/TM-163, Argonne 
National Laboratory, Argonne, IL, 2001). Available at http:/www.transportation.anl.gov/pdfs/TA/153.pdf

Weidema B. Avoiding co-product allocation in life-cycle assessment. Journal of Industrial Ecology. 2000:4 Summer 11-33

West, T.O. and G. Marland. 2002. A synthesis of carbon sequestration, carbon emissions, and net carbon flux in agriculture: comparing tillage practices in the United States.

Agriculture, Ecosystems, and Environment vol. 91 pgs.217-232.

Wikipedia, 2008. Oil Refinery. Available at http://en.wikipedia.org/wiki/Oil_refinery Accessed October 7, 2008

Worrell E., Phylipsen D., Einstein D and N. Martin. 2000. Energy use and energy intensity of the US chemical industry. Ernest Orlando Lawrence Berkeley National Laboratory. Publication no, LBNL-44314. 40 pgs

Zhang, Y., Habibi, S., MacLean, H.L. Environmental and Economic Evaluation of Bioenergy in Ontario, Canada. Journal of the Air \& Waste Management Association. 57. 2007. 919-933. 


\section{APPENDICES}




\section{Appendix A - Discussion of terms used in thesis}

Using LCA to evaluate biofuels has received considerable attention (Cheminfo 2008, Larson 2005, Malca and Friere 2006, von Blottnitz and Curran, 2007). There is also a related but separate body of research which, although requiring full a production chain scope, does not cite or rely on standard LCA guidance. This research is characterized by a focus on energy balance and is mostly U.S. based research (,Dias de Oliveira et al. 2005, Hammerschlag 2006, Hill et al. 2006, Farell et al 2006, Patzek 2004, Pimental 2003, Pimental and Patzek, 2005).

The separate bodies of literature and the relative newness of the LCA method have led to a situation in which many terms are used imprecisely and this in turn can threaten the quality of assessments of biofuels. Hence it is important to come to a common understanding of key terms:

Energy balance - Energy balance is critical to our understanding biofuels. Energy inputs to biofuels are substantial but not fully known The term is broadly and widely used to describe the result of energy analyses of biofuels. A positive net energy balance means that more energy is available from burning a biofuel that the sum of all energy required to produce it, a negative means the inverse. Energy balances have been expressed in a variety of ways; as total net energy requirements per litre of fuel (Farrell et al 2006), as a percentage of available energy (Pimentel, 2003) and often as an efficiency ratio of total energy available / divided by total fossil energy required (e.g., Graboski, 2002, Levelton, 2000, GHGenius 2007, Pimental 2003, Hammerschlag 2006). 
Energy balance analyses arose out of energy analysis work first published in the 1970s (e.g. Boustead and Hancock, 1979, Chambers, 1979). Boustead and Hancock's 1979 text (p.15) aims to develop procedures to calculate the "energy associated with all of the operations needed to support the production of a commodity or the production of a service".

Fossil fuel - Fossil fuel use is one of the impacts reported here and is the type of fuel that biofuel aims to replace. Fossil fuels are finite mineral resources of oil, coal or natural gas, chemically they are composed mainly of carbon bonded with hydrogen. Hydrocarbons are formed by the decomposition of plants and animals and forces of pressure and temperature over geologic time. When burned, these hydrocarbon materials release energy. Energy from fossil fuels is termed fossil energy, which is used directly as a combustion fuel or indirectly as in the case of electricity. The distinction between fossil energy and bioenergy is that bioenergy uses biological compounds as energy sources.

Technically, since all fossil fuels in this study are reported on a joule basis (i.e., energy measurement), fossil energy should be the appropriate term for this impact. Yet "fuel" is a more understandable term that brings to mind barrels of oil or natural gas pipelines. In other words "fuel" reminds the reader that it is a resource that is consumed and not only a physically abstract "energy" concept.

Life cycle - Life cycle is a key concept which emphasizes that products have long production chains involving multiple stages. Many reports (e.g., Groode and Heywood 
2007, Levelton, 2000, Kim and Dale 2002,) and models (e.g., GREET, 2007, GHGenius, 2007) introduce their work as life-cycle based or examinations of the life cycle stages of a biofuel. The International Organization for Standardization defines life cycle as "consecutive and interlinked stages of a product system, from raw material acquisition or generation from natural resources to final disposal" (ISO, 2006a, p.2.) In the case of E5 fuel, the life-cycle includes the farming activities used to produce corn, the milling and fermenting of corn to ethanol in an ethanol plant, the extraction of crude oil and refining into gasoline, the blending of fuels, the retail sale of the product at the pump, and the burning of the product in a vehicle engine.

Supply chains are perhaps more familiar to scholars in Geography than life-cycles. For example, Ilbery and Maye (2005) examined the supply chain of alternative / locally grown food in an effort to determine differences between alternative and conventional food supply systems. Supply chain and life cycle are synonyms.

Life-cycle assessment - Life cycle assessment or LCA is the preferred tool in use for evaluating biofuel environmental impacts. Experts agree that the basic model for LCA was developed in the early 1990s around a US based organization The Society of Environmental Toxicology and Chemistry (SETAC) (Hendrickson, 20006, Curran, 1996, Klopffer 2006). The name "LCA" and the basic structure of inventory, impact assessment and improvement came out of a SETAC workshop held in Vermont in 1990. Kloppfer (2006) lists the proponents as industrial companies (e.g., Proctor and Gamble, TetraPak), 
public research institutes (e.g. University of Leiden CML) and LCA consultants (e.g., Franklin Associates).

Under the umbrella of SETAC, a series of workshops were held in Europe and other locations and in 1993 "A Code of Practices" was finalized. In 1997, the International Organization for Standardization (ISO) standardized the LCA methodology in a series of standards - ISO 14040 "Environmental Management - Life Cycle Assessment principles and framework" is the main document and a second edition was published in late 2006. According to ISO (2006a, p.v) "life cycle assessment studies the environmental aspects and potential impacts throughout a product's life (i.e. cradle to grave) from raw material acquisition, through production, use and disposal."

LCA-type evaluation - Recognizing that LCA is a new field and there is a history of similar assessment types, the term "LCA-type evaluation" is used in this thesis. This term is meant to accommodate assessments known as energy balance analyses (e.g., Pimental, 2003), life cycle energy analyseis (e.g, Malca and Friere), well-to-wheel analysis (GREET, 2007), formal LCA (e.g. Maclean et al, 2000) or other forms of predictive greenhouse gas modelling (e.g., Searchinger et al). Given the fact that all of these assessments aim to represent the impacts of biofuel across multiple stages of the product life and LCA is arguably the most developed method for the purpose, the grouping of all assessments is valid. 


\section{$\underline{\text { Appendix B - Flow diagrams and discussion }}$}

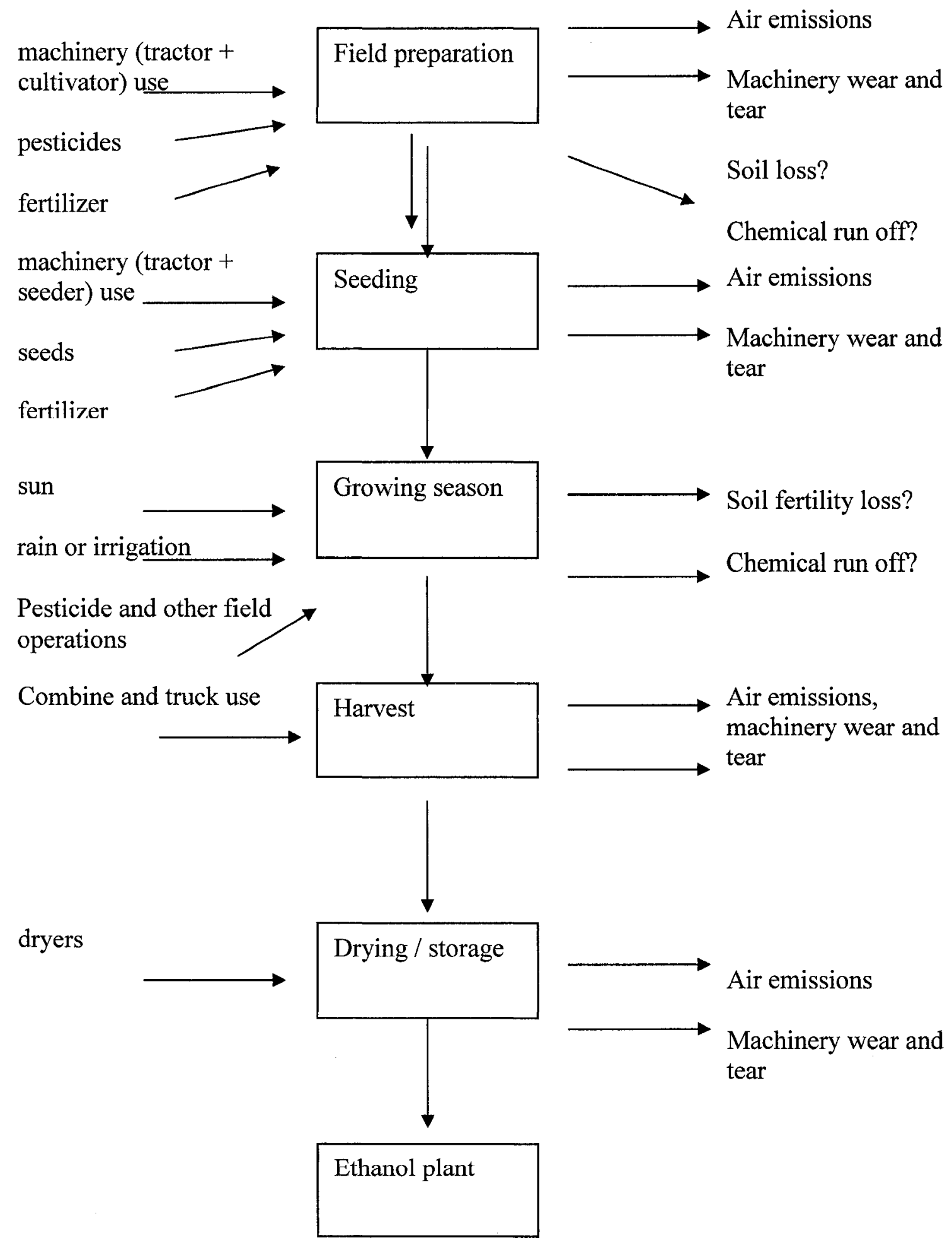

Figure B.1- Unit process diagram for foreground stage \#1 - farming corn 


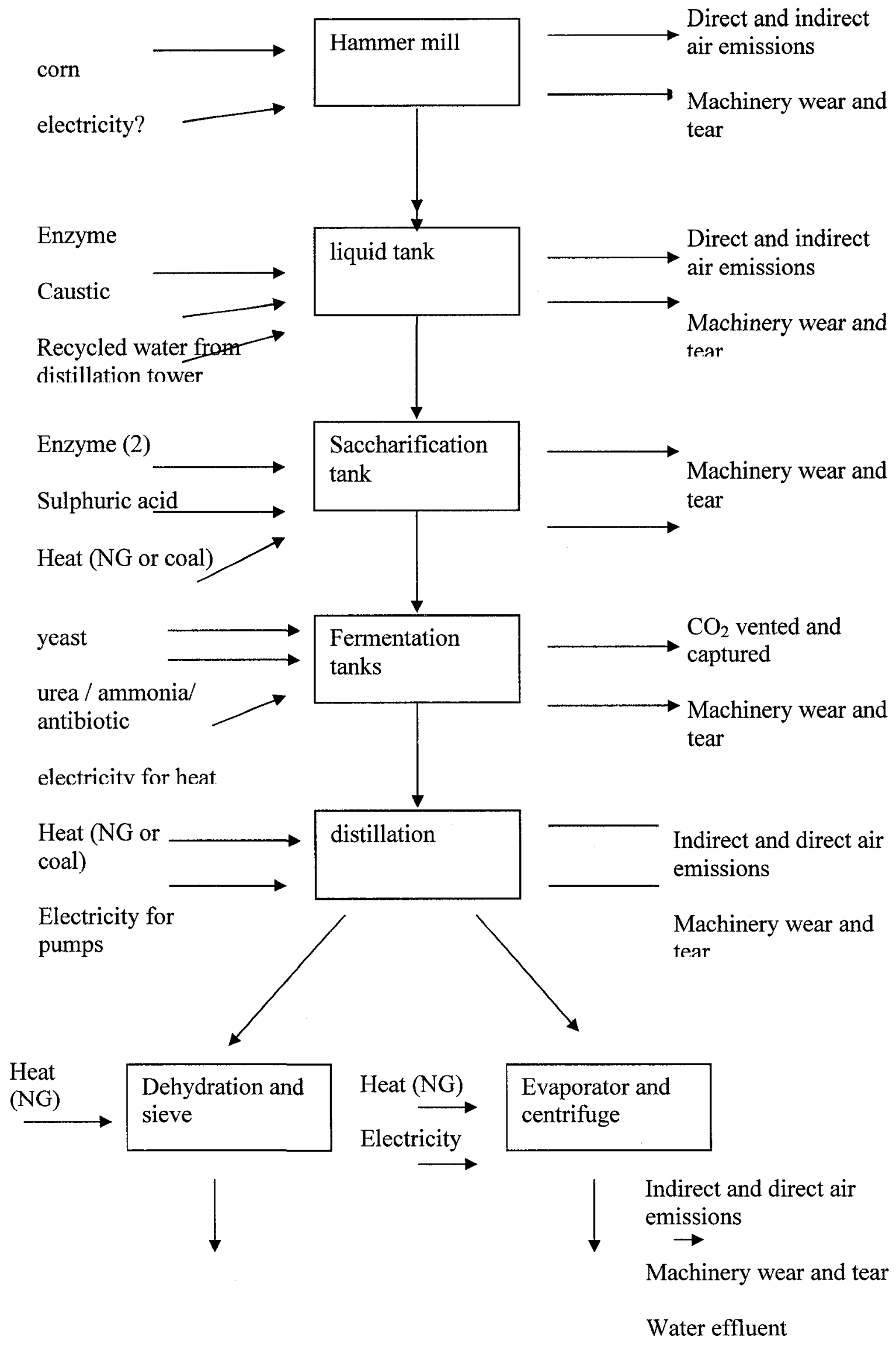




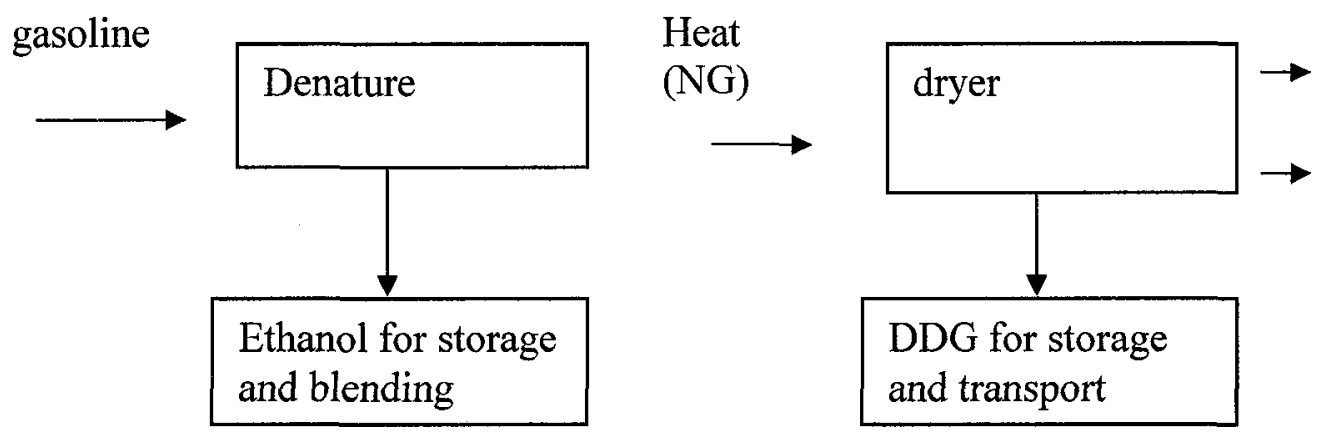

Figure B.2-Unit process diagram for foreground activity \#2 - ethanol production

From the generic foreground / background conception a series of more detailed production flow diagrams were constructed to help decide which individual activities fall within the scope of the boundary. This allows the analyst to describe the unit processes ${ }^{9}$ for which data should be collected. Figure B.1 and B.2 represent the flow of the product in the foreground system first for stage \#1 (farming corn) and then for stage \#2 ( converting corn to ethanol). The boxes in these diagrams represent unit processes and the arrows indicate flows of material or energy for the particular process.

\footnotetext{
9 "unit process" is a widely used term in ISO 14044. It is obliquely defined in the document as "smallest element considered in the life cycle inventory analysis for which input and output data are quantified". In accordance with common usage (e.g. Lee and Inaba, 2004), this thesis considers a unit process as an individual component of the production system that transforms inputs (raw materials) into outputs (products).
} 


\section{Appendix C - Consent form}

Consent Form - Sharing of inventory information with Stewart Fast, MA student Carleton University for academic thesis "Location and Biofuels: Comparison of energy requirements and greenhouse gas emission for corn ethanol produced in different regions"

Project description

The main objective of this project is to compare the energy and greenhouse gas (GHG) profile for two different ethanol production locations in Ontario. The locations selected for the study are places with active or soon to be active ethanol refineries and surrounding corn growing operations in southern Ontario, (Lambton county) and eastern Ontario (Leeds-Grenville county and Ottawa Division).

Information requested

In order to compare the energy requirements accurately, I need detailed information on the fuel and material inputs going into making corn. These include details on diesel use, fertiliser application, machinery use, drying energy and other factors.

How the information will be used

This information will be recorded and analyzed. It will be put into basic formulas to calculate total energy and GHG for the product. It will be presented in aggregated form, but particular inputs could also be highlighted. The report will be a thesis document, plus oral presentation to university audience and potentially conferences and a research paper published in an academic journal. These reports will all take place within 2008- 2009. After this point the data will be kept securely and will be used only with your permission.

Consent request

The sharing of your farm information for academic purposes may involve potential risks which you should consider. These risks could include inadvertent sharing of confidential or proprietary information, or risks from unauthorised representation of the company.

You may refuse to answer any or all questions asked. Should you decide to withdraw from the study you may decide at that time if I may use any portion of the information you have provided or you may request that all the information be destroyed.

Please sign here to indicate that you understand my intentions with the information and that you consent to the use of the information in this academic thesis project. 


\section{Appendix D -Corn farming stage inventory data (Gen.Ont, S.Ont, E.Ont)}

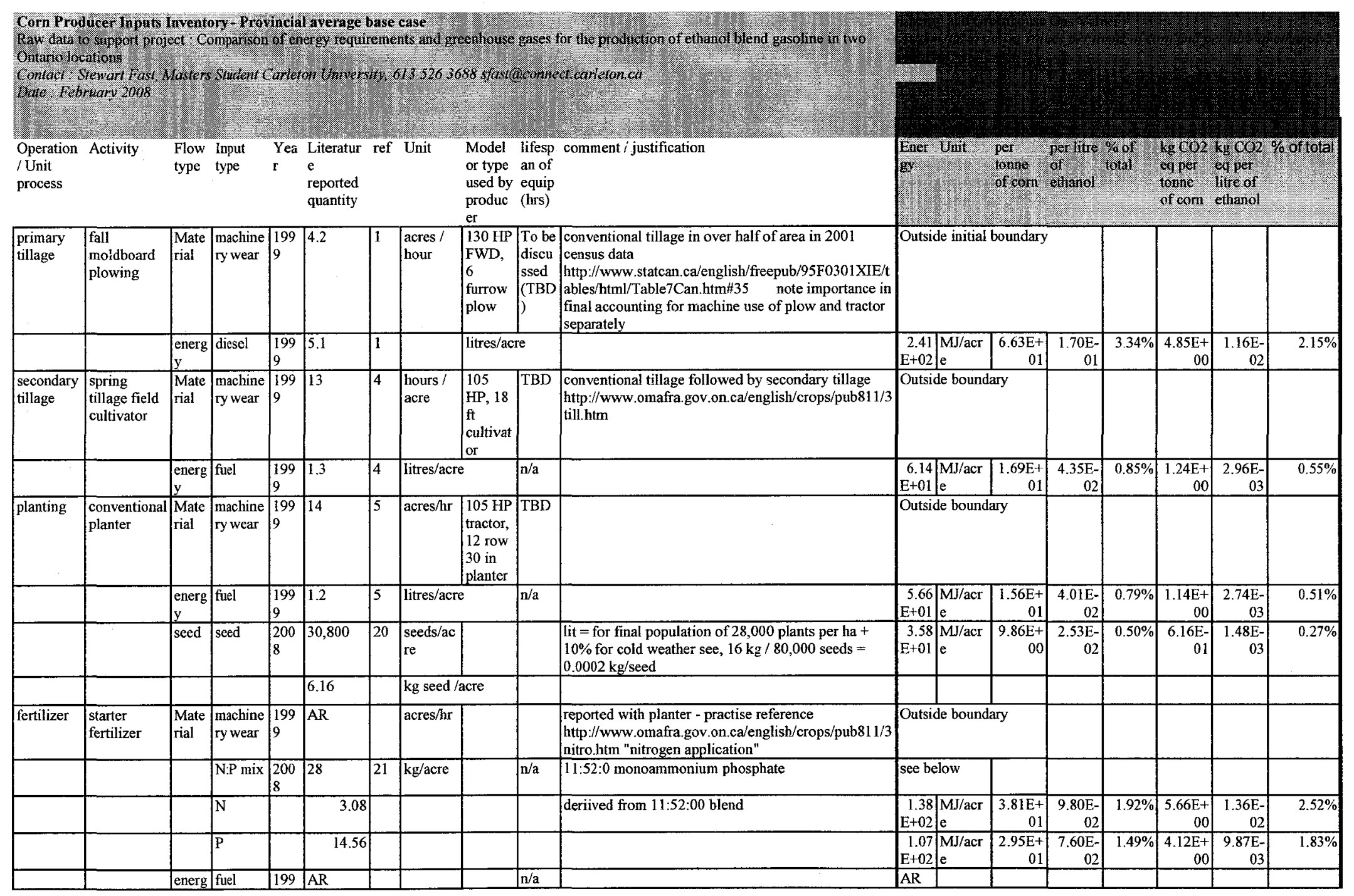

Appendices 


\begin{tabular}{|c|c|c|c|c|c|c|c|c|c|c|c|c|c|c|c|c|c|c|}
\hline & & y & & 9 & & & & & & & & & & & & & & \\
\hline & \begin{tabular}{|l} 
Nitrogen \\
pre- \\
emergence \\
combined \\
with \\
planting \\
\end{tabular} & $\begin{array}{l}\text { Mate } \\
\text { rial }\end{array}$ & $\begin{array}{l}\text { machine } \\
\text { ry wear }\end{array}$ & 200 & $\begin{array}{l}\text { Already } \\
\text { reported }(A\end{array}$ & (AR) & acres/hr & & AR & $\begin{array}{l}\text { exact same values as for planter (make sure to count } \\
\text { only once) }\end{array}$ & Outsid & de bound & & & & & & \\
\hline & & & $\begin{array}{l}\text { Nitroge } \\
\text { n }\end{array}$ & $\begin{array}{r}200 \\
5\end{array}$ & 66 & 7 & $\mathrm{~kg} / \mathrm{acre}$ & & $\mathrm{n} / \mathbf{a}$ & lit $236 \mathrm{~kg}$ of urea ammonium nitrate $(28: 0: 0)$ & $\begin{array}{r}2.97 \\
\mathrm{E}+03 \\
\end{array}$ & $\begin{array}{l}\mathrm{MJ} / \mathrm{acr} \\
\mathrm{e}\end{array}$ & $\begin{array}{r}8.17 \mathrm{E}+ \\
02 \\
\end{array}$ & $\begin{array}{r}2.10 \mathrm{E}+ \\
00 \\
\end{array}$ & $41.16 \%$ & $\begin{array}{r}1.21 \mathrm{E}+ \\
02 \\
\end{array}$ & \begin{tabular}{rl|}
$2.91 \mathrm{E}-$ \\
01 \\
\end{tabular} & $53.94 \%$ \\
\hline & & $\begin{array}{l}\text { energ } \\
y\end{array}$ & fuel & $\begin{array}{r}200 \\
5\end{array}$ & AR & & litres/acre & & $\mathrm{n} / \mathrm{a}$ & & AR & & & & & & & \\
\hline & $\begin{array}{l}\text { Phospate } \\
\text { with } \\
\text { planting }\end{array}$ & & & & & & & & & already reported under starter fertilizer & $\mathrm{AR}$ & & & & & & & \\
\hline & $\begin{array}{l}\begin{array}{l}\text { Potassium } \\
\text { (Potash) } \\
\text { broadcast }\end{array} \\
\end{array}$ & $\begin{array}{l}\text { Mate } \\
\text { riai }\end{array}$ & $\begin{array}{l}\text { machine } \\
\text { ry wear }\end{array}$ & 199 & ? & & acres/hr & & & $\begin{array}{l}\text { practise reference - } \\
\text { http://www.omafra.gov.on.ca/english/crops/pub811/3 } \\
\text { phospo.htm }\end{array}$ & AR & & & & & & & \\
\hline & & & Potash & $\begin{array}{r}200 \\
5\end{array}$ & 19.2 & 9 & $\mathrm{~kg} / \mathrm{acre}$ & & $\mathrm{n} / \mathrm{a}$ & lit $32 \mathrm{~kg}$ muriate of potash $(0-0-60)$ & $\begin{array}{r}6.05 \\
\mathrm{E}+01 \\
\end{array}$ & $\begin{array}{l}\mathrm{MJ} / \mathrm{acr} \\
\mathrm{e}\end{array}$ & $\begin{array}{r}1.67 \mathrm{E}+ \\
01 \\
\end{array}$ & $\begin{array}{r}4.28 \mathrm{E}- \\
02 \\
\end{array}$ & $0.84 \%$ & $\begin{array}{r}1.47 \mathrm{E}+ \\
01 \\
\end{array}$ & $\begin{array}{r}3.52 \mathrm{E}- \\
02 \\
\end{array}$ & $6.52 \%$ \\
\hline & & $\begin{array}{l}\text { energ } \\
\text { y }\end{array}$ & fuel & $\begin{array}{r}200 \\
5 \\
\end{array}$ & 2.1 & & 1/acre & & & $\begin{array}{l}\text { tractor and pull broadcast spreader - estimate from } \\
\text { Ottawa case - weak data }\end{array}$ & \begin{tabular}{rl|}
9.91 \\
$E+01$ \\
\end{tabular} & $\begin{array}{l}\mathrm{MJ} / \mathrm{acr} \\
\mathrm{e}\end{array}$ & $\begin{array}{r}2.73 \mathrm{E}+ \\
01 \\
\end{array}$ & \begin{tabular}{rl|}
$7.02 \mathrm{E}-$ \\
02 \\
\end{tabular} & $1.38 \%$ & $\begin{array}{r}2.00 \mathrm{E}+ \\
00\end{array}$ & \begin{tabular}{rl|}
$4.79 \mathrm{E}-$ \\
03
\end{tabular} & $0.89 \%$ \\
\hline & $\begin{array}{l}\text { Micronutrie } \\
\text { nt addition }\end{array}$ & & & & & & & & & not included - not prevalent hittp://www.omafra.gov.o & n.ca/eng & glish/crop & ps/pub811 & $1 / 3$ secmic & chtm & & & \\
\hline & Lime & & & & & & & & & not included - not prevalent & & & & & & & & \\
\hline & & & $\begin{array}{l}\text { herbicid } \\
\text { e }\end{array}$ & $\begin{array}{l}200 \\
8\end{array}$ & 2.88 & 12 & $\mathrm{~kg} / \mathrm{ha}$ & & $\mathrm{n} / \mathrm{a}$ & lit = primextra II magnum & $\begin{array}{r}7.03 \\
\mathrm{E}+02 \\
\end{array}$ & MJ/ha & $\begin{array}{r}7.84 \mathrm{E}+ \\
01 \\
\end{array}$ & $\begin{array}{r}2.02 \mathrm{E}- \\
01\end{array}$ & $3.95 \%$ & $\begin{array}{r}8.03 \mathrm{E}+ \\
00\end{array}$ & $\begin{array}{r}1.93 \mathrm{E}- \\
02\end{array}$ & $3.57 \%$ \\
\hline & & $\begin{array}{l}\text { energ } \\
\mathrm{y}\end{array}$ & fuel & $\begin{array}{l}199 \\
9\end{array}$ & 0.4 & 11 & litres/acre & & na $/ a$ & & \begin{tabular}{r|}
1.89 \\
$\mathrm{E}+01$ \\
\end{tabular} & $\begin{array}{l}\mathrm{MJ} / \mathrm{acr} \\
\mathrm{e}\end{array}$ & $\begin{array}{r}5.20 \mathrm{E}+ \\
00 \\
\end{array}$ & \begin{tabular}{|r|}
$1.34 \mathrm{E}-$ \\
02 \\
\end{tabular} & $0.26 \%$ & $\begin{array}{r}3.80 \mathrm{E}- \\
01 \\
\end{array}$ & $\begin{array}{r}9.12 \mathrm{E}- \\
04 \\
\end{array}$ & $0.17 \%$ \\
\hline insecticide & seed applied & $\begin{array}{l}\text { Mate } \\
\text { rial }\end{array}$ & & $\begin{array}{l}200 \\
7\end{array}$ & AR & & acres/lır & & AR & & Outsid & de bounda & & & & & & \\
\hline & & & $\begin{array}{l}\text { insectici } \\
\text { de }\end{array}$ & $\begin{array}{l}200 \\
7\end{array}$ & 0.02 & & $\mathrm{~kg} /$ acre & & $\mathrm{n} / \mathbf{a}$ & $\begin{array}{l}\text { Poncho is common on about } 80 \% \text { of farms (GS } \\
\text { OMAFRA) rate is } 0.25 \mathrm{mg} / \mathrm{kernel}\end{array}$ & $\begin{array}{r}3.76 \\
E+00 \\
\end{array}$ & $\begin{array}{l}\mathrm{MJ} / \mathrm{acr} \\
\mathrm{e}\end{array}$ & \begin{tabular}{|r|}
$1.03 \mathrm{E}+$ \\
00 \\
\end{tabular} & \begin{tabular}{|r|}
$2.66 \mathrm{E}-$ \\
03 \\
\end{tabular} & $0.05 \%$ & $\begin{array}{r}1.06 \mathrm{E}- \\
01 \\
\end{array}$ & $\begin{array}{r}2.54 \mathrm{E}_{-} \\
04 \\
\end{array}$ & $0.05 \%$ \\
\hline & & $\begin{array}{l}\text { energ } \\
y\end{array}$ & fuel & $\begin{array}{l}199 \\
9\end{array}$ & AR & & litres/ac & & n/a & & AR & & & & & & & \\
\hline fungicide & seed applied & \begin{tabular}{|l} 
mater \\
ial
\end{tabular} & $\begin{array}{l}\text { fungicid } \\
\text { e }\end{array}$ & 200 & 0.00 & & $\mathrm{~kg} / \mathrm{acre}$ & & & $\begin{array}{l}\text { Assume fludioxinol at } 10.4 \mathrm{mg} / 100 \mathrm{~kg} \text { of seed from } \\
\text { OMAFRA Corn fusarium reference (\#14). Know } \\
\text { seeding rate per acre and that } 80,000 \text { kernels weighs } \\
16 \mathrm{~kg}\end{array}$ & \begin{tabular}{|r|}
1.53 \\
$\mathrm{E}-04$
\end{tabular} & $\mathrm{e}^{\mathrm{MJ} / \mathrm{acr}}$ & $\begin{array}{r}4.22 \mathrm{E}- \\
05\end{array}$ & $\begin{array}{r}1.09 \mathrm{E}-\mathrm{P} \\
07\end{array}$ & $0.00 \%$ & $\begin{array}{r}4.32 \mathrm{E}- \\
06\end{array}$ & $\begin{array}{r}1.04 \mathrm{E}- \\
08\end{array}$ & $0.00 \%$ \\
\hline irrigation & & & & & & & & & & $\begin{array}{l}\text { n/a - less than } 1 \% \text { of all farm ha irrigated in province } \\
\text { http://www.statcan.ca/english/freepub/95F0301XIE/ta } \\
\text { source) }\end{array}$ & ables/ht & $\mathrm{tm} / \mathrm{Ta}$ & 8Can.htm & $\mathrm{n} \# 35$ (ass & sumes 5,4 & $66,223 \mathrm{fr}$ & om table & of same \\
\hline harvest & combine & \begin{tabular}{|l|} 
mater \\
ial
\end{tabular} & $\begin{array}{l}\text { machine } \\
\text { ry wear }\end{array}$ & $\begin{array}{l}199 \\
9\end{array}$ & 7.6 & 15 & acres/hr & $\begin{array}{l}275 \mathrm{hp} \\
12 \text { row } \\
30 \text { in } \\
\end{array}$ & TDB & & & & & & & & & \\
\hline & & $\begin{array}{l}\text { energ } \\
y\end{array}$ & fuel & \begin{tabular}{|l|}
199 \\
9
\end{tabular} & 6 & 15 & litres/ac & & $\mathrm{n} / \mathbf{a}$ & & \begin{tabular}{|r|}
2.83 \\
$\mathrm{E}+02$ \\
\end{tabular} & $\begin{array}{l}\mathrm{MJ} / \mathrm{acr} \\
\mathrm{e}^{-}\end{array}$ & \begin{tabular}{|r|}
$7.80 \mathrm{E}+$ \\
01 \\
\end{tabular} & $\begin{array}{r}2.01 \mathrm{E}- \\
01 \\
\end{array}$ & $3.93 \%$ & $\begin{array}{r}5.70 \mathrm{E}+ \\
00 \\
\end{array}$ & \begin{tabular}{|r|}
$1.37 \mathrm{E}-$ \\
02
\end{tabular} & $2.53 \%$ \\
\hline
\end{tabular}




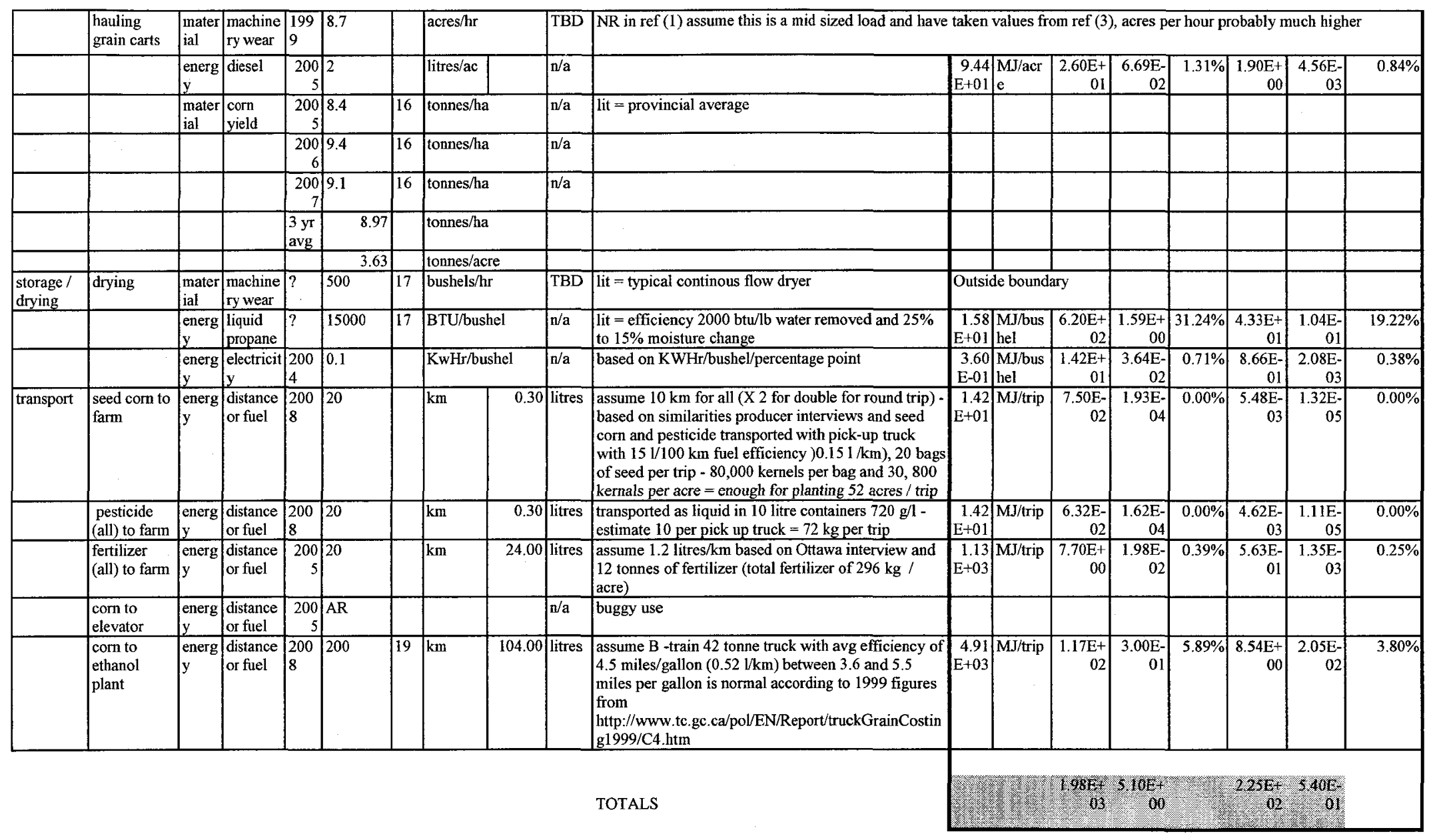




\section{References for Gen.Ont corn stage 1 quantities}

(1) moldboard plow from American Society of Agricultural Engineers Standards, American Society of Agricultural Engineers, 1999 reproduced in OMAFRA Guide To Custom Farmwork and Short-Term Equipment Rental (table 7) 2007 http://www.omafra.gov.on.ca/english/busdev/facts/07-019.htm\#table7

(2) chisel plow ibid (1)

(3) tandem disk ibid (1)

(4) field cultivator ibid (1)

(5) row planter ibid (1)

(6) min till planter ibid (1)

(7) $\mathrm{kg}$ of UAN from OMAFRA 2008 corn field budget http://www.omafra.gov.on.ca/english/busdev/facts/pub60.htm\#grain note more regional accuracy potentially possible usign $\mathrm{N}$ recommendation table http://www.omafra.gov.on.ca/english/crops/facts/fert-rectables-4.htm

(8) $\quad \mathrm{kg}$ of MAP ibid (7)

(9) $\quad \mathrm{kg}$ of muriate of potash ibid (7)

(10) glyphosate from top table of 'burndown" recommendations for Corn from OMAFRA Guide to Weed Control publication 75

(11) sprayer fuel and hours from ibid (1)

(12) primextra II magnum from 2nd table of "post emergence broadleaf and grass" ibid (10) http://www.omafra.gov.on.ca/english/crops/pub75/9corpgb.htm

(13) tefluthrin applied at planting from OMAFRA field crop protection guide publication 812 http://www.omafra.gov.on.ca/english/crops/pub812/2crw.htm

(14) fludioxinol applied to seed at plantign from ibid (13) http://www.omafra.gov.on.ca/english/crops/pub812/2fussb.htm

(15) combine ibid (1)

(16) OMAFRA Estimated Area, Yield, Production and Farm Value of Specified Field Crops, Ontario, 2001-2007 http://www.omafra.gov.on.ca/english/stats/crops/estimate_metric.htm

(17) Mississipi State University Extension Service. Corn Harvesting Drying and Storage publication 22852005

(17b) Energy Costs for Corn Drying and Cooling -Biological Systems Engineering University of Minnesotta - pub no. P102-2004-09 http://www. bbe.umn.edu/ennotes/P/P102-2004-09.htm

(18) OMAFRA factsheet. Natural Air Corn Drying Systems 86-0866 http://www.omafra.gov.on.ca/english/crops/facts/86-066.htm

(19) based on Varennes refinery estimate personal communication Feb 2008, $100 \mathrm{~km}$ supply radius, $200 \mathrm{~km}$ for round trip (not all trucks empty)

(20) lit $=$ for final population of 28,000 plants per ha $+10 \%$ for cold weather see $\mathrm{http}: / / \mathrm{www}$. omafra.gov.on.ca/english/crops/pub811/3plant.htm

(21) OMAFRA field crop budget field crop budget ref http://www.omafra.gov.on.ca/english/busdev/facts/pub60.htm\#grain 


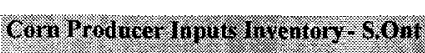

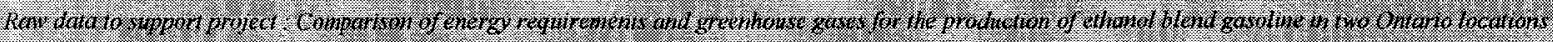

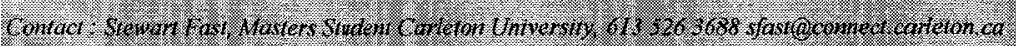

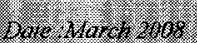

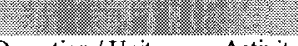

Activity

Flow type

Input type

Year $\quad$ Producer reported Unit

quantity

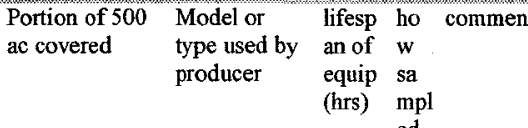

(hrs) $\mathrm{mpl}$

\begin{tabular}{|c|c|c|c|c|c|c|c|c|c|c|}
\hline primary tillage & & & & & & & & & & not done - no till \\
\hline secondary tillage & & & & & & & & & & not done - no till \\
\hline \multirow[t]{4}{*}{ planting } & no-till planter & Material & machinery wear & 2005-7 & 7 & acres/hr & All & & $\begin{array}{l}12000 \\
\text { (tractor) }\end{array}$ & producer $=\mathrm{J}$ deere 4850,12 row and 20 in \\
\hline & & energy & fuel & $2005-7$ & 2.85 & litres/acre & All & & \begin{tabular}{|l|l}
$\mathrm{n} / \mathrm{a}$ & \\
\end{tabular} & \\
\hline & & seed & seed & 2007 & 32500.00 & seeds/acre & All & & & \\
\hline & & & & 2007 & 6.50 & kg seed/acre & All & & & $16 \mathrm{~kg} / 80,000 \mathrm{seeds}=0.0002 \mathrm{~kg} / \mathrm{secd}$ \\
\hline \multirow[t]{12}{*}{ fertilizer } & starter fertilizer & Material & machinery wear & $2005-7$ & $\widehat{\mathrm{AR}}$ & & All & & & \\
\hline & & & $\mathrm{N}: \mathrm{P}$ mix & $2005-7$ & 4.50 & gallons/ac & All & $7: 26: 0$ starter & n/a & $\begin{array}{l}\text { producer }=7: 26: 0 \text { NPK liquid, assume } 11 \\
\text { lb/gallon } \\
\text { (http://www.agry.purdue.edu/ext/corn/news/ } \\
\text { articles.02/Fert_Math-0326.html) }\end{array}$ \\
\hline & & & Nitrogen & & 1.57 & $\mathrm{~kg} / \mathrm{acre}$ & & & & \\
\hline & & & Phosphate & & 5.84 & $\mathrm{~kg} /$ acre & & & & \\
\hline & & energy & fuel & $2005-7$ & $\mathrm{AR}$ & $\mathrm{n} / \mathrm{a}$ & All & $\mathrm{n} / \mathbf{a}$ & $\mathrm{n} / \mathrm{a}$ & part of planting \\
\hline & $\begin{array}{l}\text { Nitrogen pre- } \\
\text { emergence combined } \\
\text { with planting }\end{array}$ & Material & machinery wear & $2005-7$ & $\mathrm{AR}$ & & All & & & \\
\hline & & & Nitrogen & $2005-7$ & 115 & $\mathrm{lb} / \mathrm{ac}$ & All & & $\mathrm{n} / \mathrm{a}$ & \\
\hline & & energy & fuel & $2005-7$ & $\widehat{\mathrm{AR}}$ & litres/acre & All & & $\mathrm{n} / \mathrm{a}$ & \\
\hline & $\begin{array}{l}\text { Phosphate with } \\
\text { planting }\end{array}$ & & & & $\widehat{A R}$ & & All & & & part of starter fertilizer \\
\hline & \multicolumn{2}{|c|}{ Potassium (Potash) broadcast } & Potash & 2007 & 150 & lb/ac (producer) & 100 acres & & & $5: 26: 30$ granular mix - bulk spreader \\
\hline & & & & 2005,2006 & 0 & $\mathrm{lb} / \mathrm{ac}$ & All & & & $\begin{array}{l}\begin{array}{l}\text { producer reported } 150 \mathrm{lbs} \text { total on } 100 \text { acres } \\
\text { in I year }\end{array} \\
\text { ing }\end{array}$ \\
\hline & & & & $07-07$ & 4.54 & $\mathrm{~kg} / \mathrm{acre}$ & & & & $\begin{array}{l}\text { to put on a } 3 \text { yr average and all acreage and } \\
\text { convert to } \mathrm{kg}\end{array}$ \\
\hline
\end{tabular}




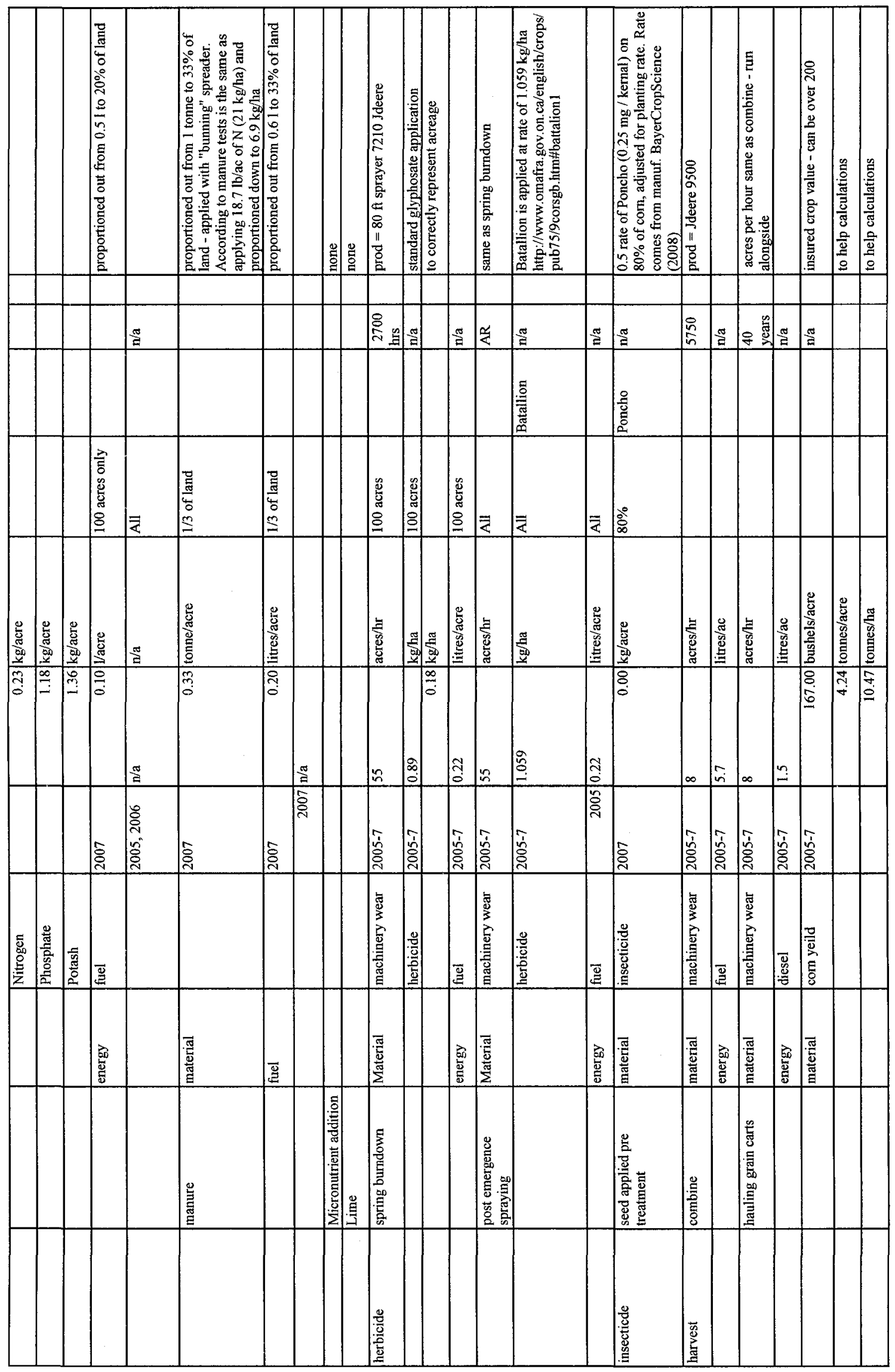

ถ 


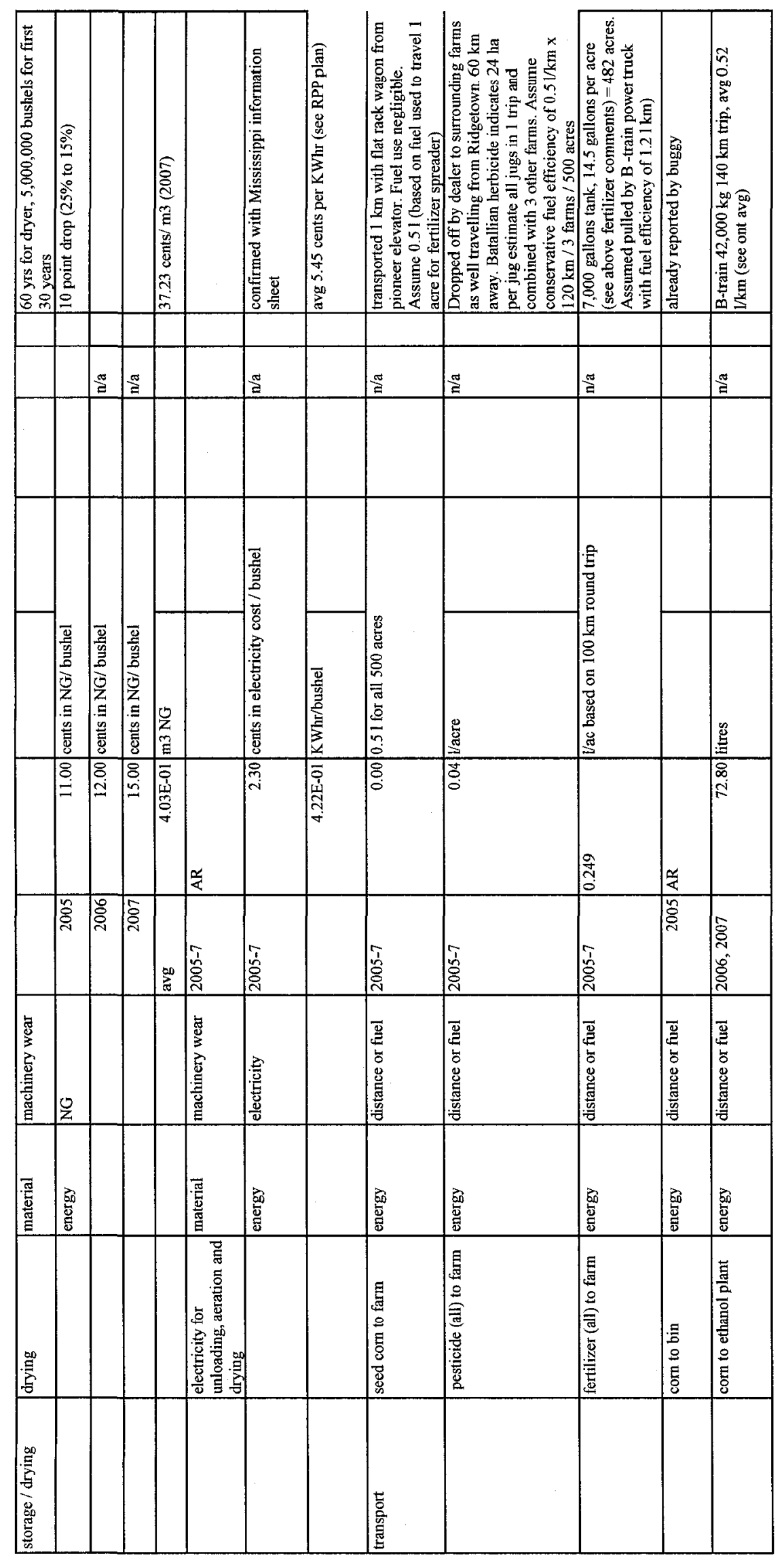

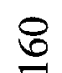




\begin{tabular}{|c|c|c|c|c|c|c|c|c|c|}
\hline \\
\hline \multicolumn{10}{|c|}{ 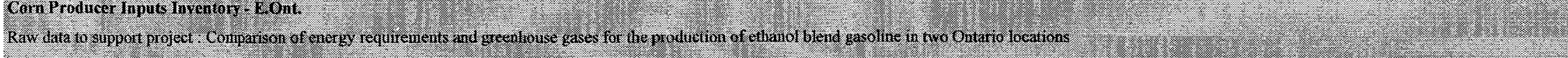 } \\
\hline \multicolumn{10}{|c|}{ 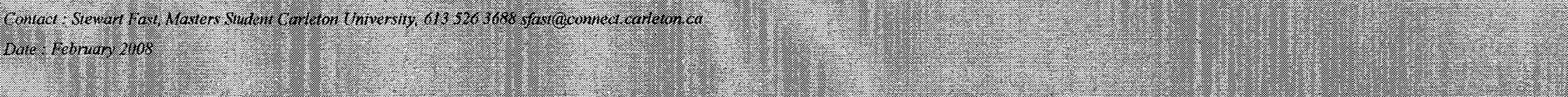 } \\
\hline $\begin{array}{l}\text { Operation / Unit } \\
\text { process }\end{array}$ & Activity & Flow type & Input type & Year & $\begin{array}{l}\text { Producer reported } \\
\text { quantity }\end{array}$ & Unit & $\begin{array}{l}\text { Model or } \\
\text { type used } \\
\text { by } \\
\text { producer }\end{array}$ & $\begin{array}{l}\text { lifespan of equip } \\
\text { (hrs) }\end{array}$ & comment \\
\hline \multirow[t]{3}{*}{ primary tillage } & fall mulch tillage - disc & Material & machinery wear & $2005-7$ & 5 & acres/hr & & TBD & $\begin{array}{l}\text { "disc ripper - shanks and dises" } 12 \text { foot } 6 \text { inch pulld by } \\
8300 \mathrm{JD}\end{array}$ \\
\hline & & Fuel & fuel & $2005-7$ & 10 & hours/tank & & $\mathrm{n} / \mathbf{a}$ & \\
\hline & & & & & 10.20 & litres/ac & & & 510 litre capacity in $8300 ?$ \\
\hline \multirow[t]{3}{*}{ secondary tillage } & spring mulch- finisher & Material & machinery wear & $2005-7$ & 7 & hours / acre & & TBD & 25 foot teeth, discs and harrow pulled by $8300 \mathrm{JD}$ \\
\hline & & energy & fuel & $2005-7$ & 13.00 & hours/tank & & $\mathrm{n} / \mathrm{a}$ & 2 passes on $28 \%$ of corn to control weeds \\
\hline & & & & & 7.17 & litres/acre & & & \\
\hline \multirow[t]{5}{*}{ planting } & conventional planter & Material & machinery wear & $2005-7$ & 12 & acres $/ \mathrm{hr}$ & & TBD & \\
\hline & & energy & fuel & $2005-7$ & 10.00 & hours/tank & & $\mathrm{n} / \mathbf{a}$ & 7930 Jdeere 12 row, 30 foot planter \\
\hline & & & & & 3.24 & litres/acre & & & \\
\hline & & seed & seed & $2005-7$ & 32,000 & seeds/acre & & & \\
\hline & & & & & 6.40 & kg seed/acre & & & 1 seed $=.0002 \mathrm{~kg}$ (see Ont sheet) \\
\hline \multirow[t]{12}{*}{ fertilizer } & $\begin{array}{l}\text { starter pre-secondary } \\
\text { tillage }\end{array}$ & Material & machinery wear & $2005-7$ & 20 & acres $/ \mathrm{hr}$ & & & 7410 Jdeere with spreader \\
\hline & & & NPK & $2005-7$ & 130 & lb/acre & & $\mathrm{n} / \mathbf{a}$ & NPK 9:43:10 \\
\hline & & & & & 59.09 & $\mathrm{~kg} / \mathrm{acre}$ & & & \\
\hline & & & nitrogen & $2005-7$ & 5.32 & $\mathrm{~kg} / \mathrm{acre}$ & & & \\
\hline & & & phosphate & $2005-7$ & 25.41 & $\mathrm{~kg} / \mathrm{acre}$ & & & \\
\hline & & & potash & 2005-7 & 5.91 & $\mathrm{~kg} / \mathrm{acre}$ & & & \\
\hline & & energy & fuel & $2005-7$ & 20.00 & hrs/tank & & $\mathrm{n} / \mathrm{a}$ & \\
\hline & & & & & 0.47 & litres/acre & & & \\
\hline & $\begin{array}{l}\text { Nitrogen pre- } \\
\text { emergence combined } \\
\text { with planting }\end{array}$ & Material & machinery wear & $2005-7$ & $\mathrm{AR}$ & acres/hr & & AR & \\
\hline & & & Nitrogen & $2005-7$ & 375 & lb/acre & & $n / a$ & $38: 0: 10$ \\
\hline & & & & & 170.45 & kg/acre & & & convert to $\mathrm{kg} / \mathrm{ac}$ \\
\hline & & & nitrogen & & 64.77 & kg/acre & & & \\
\hline
\end{tabular}




\begin{tabular}{|c|c|c|c|c|c|c|c|c|c|}
\hline & & & potash & & 17.05 & $\mathrm{~kg} / \mathrm{acre}$ & & & \\
\hline & & energy & fiel & $2005-7$ & AR & litres/acre & & $\mathrm{n} / \mathbf{a}$ & \\
\hline \multirow[t]{4}{*}{ herbicide } & $\begin{array}{l}\text { post emergence } \\
\text { spraying }\end{array}$ & Material & machinery wear & $2005-7$ & 20 & acres $/ \mathrm{hr}$ & & TBD & $7410 \mathrm{JD}$ pulling sprayer with 60 foot boom \\
\hline & & & herbicide & $2005-7$ & 3.02 & $\mathrm{~kg} / \mathrm{ha}$ & & $\mathrm{n} / \mathbf{a}$ & $\begin{array}{l}\text { Primextra and Callista mix at recommended rate - } \\
\text { http://www.omafra.gov.on.ca/english/crops/pub75/9corst } \\
\text { m.htmmpprimextra3 }(2.88+0.14)\end{array}$ \\
\hline & & energy & fuel & $2005-7$ & 20.00 & hours / tank & & $\mathrm{n} / \mathbf{a}$ & \\
\hline & & & & & 0.47 & litres/ac & & & \\
\hline $\begin{array}{l}\text { mechanical weed } \\
\text { control }\end{array}$ & weeder harrow & Material & & & & & & & accounted for in secondary tillage section \\
\hline insecticide & seed applied & material & insecticide & 2007 & 0.02 & $\mathrm{~kg} / \mathrm{acre}$ & & & $\begin{array}{l}\text { poncho on all seeds at } 0.25 \mathrm{mg} / \mathrm{kennal} \text { (BayerCropScience } \\
2008 \text { ) }\end{array}$ \\
\hline fungicide & application & Material & & & & & & & "cruiser" treated seeds on 40 ac (2008) \\
\hline \multirow[t]{10}{*}{ harvest } & combine & material & machinery wear & $2005-7$ & 4 & acres $/ \mathrm{hr}$ & & TDB & $9500 \mathrm{JD}$ \\
\hline & & energy & fuel & $2005-7$ & 10.00 & hrs/tank & & $\mathrm{n} / \mathbf{a}$ & \\
\hline & & & & & 18.75 & litres/ac & & & \\
\hline & hauling grain carts & material & machinery wear & $2005-7$ & 4.00 & acres/lir & & TBD & $\begin{array}{l}\text { variable, sometimes to B-train truck, buggy pulled by JD } \\
7930 \ldots \text {. same as combine if driving alongside combine - if } \\
\text { not much less }\end{array}$ \\
\hline & & energy & diesel & $2005-7$ & 20.00 & hours/tank & & $\mathrm{n} / \mathbf{a}$ & \\
\hline & & & & & 2.36 & litres/acre & & & \\
\hline & & material & corn yield & $2005-7$ & 141 & bushels/acre & & $\mathrm{n} / \mathbf{a}$ & \\
\hline & & & & & 3.58 & tonnes/acre & & & \\
\hline & & & & & 8.85 & tonnes/ha & & & \\
\hline & & & & & 348.27 & bushels/ha & & & \\
\hline \multirow[t]{5}{*}{ storage / drying } & drying & material & machinery wear & $2005-7$ & 135 & bushels $/ \mathrm{hr}$ & & TBD & $\begin{array}{l}50 \% \text { of corn dried, } 50 \% \text { taken wet to Cardinal (could not } \\
\text { be done for ethanol plant) }\end{array}$ \\
\hline & & energy & liquid propane & $2005-7$ & 96.00 & I/batch & & $\mathrm{n} / \mathbf{a}$ & $26 \%$ percent moisture \\
\hline & & & & & 0.79 & 1/bushel & & & $\begin{array}{l}\text { producer reported quantity } 0.181 \text { much lower than that of } \\
0.79 \text { estimate from technical brochure - ck for sensitivity } \\
\text { - using technical brochure value }\end{array}$ \\
\hline & & energy & diesel & $2005-7$ & 8.00 & gallons/batch & & $\mathrm{n} / \mathbf{a}$ & tractor required - 540 bushel capacity \\
\hline & & & & & 0.06 & litres/bushel & & & \\
\hline \multirow[t]{3}{*}{ transport } & seed com to farm & energy & distance or fuel & $2005-7$ & 8 & $\mathrm{~km}$ & 1.20 & litres & $\begin{array}{l}\text { Same set-up as Lambton but shorter distance. Assume } \\
\text { conservative fuel efficiency of } 0.5 \mathrm{l} / \mathrm{km} \times 16 \mathrm{~km} / 500 \\
\text { acres }\end{array}$ \\
\hline & & & & & 0.02 & $1 /$ acre & & & \\
\hline & pesticide (all) to farm & energy & distance or fuel & $2006-7$ & 8 & $\mathrm{~km}$ & 1.20 & litres & included in seed \\
\hline
\end{tabular}




\begin{tabular}{|c|c|c|c|c|c|c|c|c|}
\hline & fertilizer (ail) to farm & energy & distance or fuel & $2005-7$ & 8 & $\mathrm{~km}$ & 9.60 litres & $\begin{array}{l}12 \text { tonne loads of fertilizer (assume } 0.83 \mathrm{l} / \mathrm{km} \text { ) same as B } \\
\text { train from corn to ethanol - total } 500 \mathrm{lbs} / \mathrm{acre}=0.25 \\
\text { tonnes/acre and } 12 \text { tonnes }=48 \text { acres }\end{array}$ \\
\hline & & & & & 0.20 & litres/acre & & \\
\hline & corn to storage & energy & distance or fuel & $2005-7$ & $\mathrm{AR}$ & & litres & AR in buggy \\
\hline & corn to ethanol plant & energy & distance or fuel & $2005-7$ & 180.00 & $\mathrm{~km}$ & \begin{tabular}{|l|l|}
149.40 & litres \\
\end{tabular} & $\begin{array}{l}\text { to Cardinal for com starch - not for ethanol yet (1.2 I } \\
\mathrm{km} / \mathrm{l}=0.831 / \mathrm{km}) 42,000 \mathrm{~kg} / \text { load - } 90 \mathrm{~km} \text { one way }\end{array}$ \\
\hline
\end{tabular}




\section{Appendix E - Ethanol manufacturing stage}

\begin{tabular}{|c|c|c|c|c|c|c|}
\hline 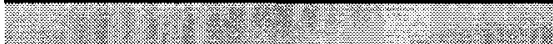 & 62 & fossil energy ( & (J func unit) & & ghg (kg CO2 / func unit) & \\
\hline use & S.Ont & E.Ont & Gen.Ont : & S.Ont & E.Ont Gen.Ont & \\
\hline heating liquid, drying feed & $2.26 \mathrm{E}+00$ & $2.26 \mathrm{E}+00$ & $2.22 \mathrm{E}+00$ & $1.30 \mathrm{E}-01$ & $1.30 \mathrm{E}-01$ & $1.28 \mathrm{E}-01$ \\
\hline \multirow{2}{*}{$\begin{array}{l}\text { running augers, other } \\
\text { breaking starch to to sugar }\end{array}$} & $1.82 \mathrm{E}-01$ & $1.82 \mathrm{E}-01$ & $1.78 \mathrm{E}-01$ & $1.02 \mathrm{E}-02$ & $1.02 \mathrm{E}-02$ & $1.09 \mathrm{E}-02$ \\
\hline & $1.16 \mathrm{E}-02$ & \multicolumn{2}{|c|}{$1.16 \mathrm{E}-02$ not reported } & $8.55 \mathrm{E}-04$ & $8.55 \mathrm{E}-04$ not reported & \\
\hline breaking corn to sugar & $2.89 \mathrm{E}-02$ & \multicolumn{2}{|c|}{$2.89 \mathrm{E}-02$ not reported } & $2.14 \mathrm{E}-03$ & 2.14E-03 not reported & \\
\hline converting sugar to alcohol & $2.25 \mathrm{E}-04$ & \multicolumn{2}{|c|}{ 2.25E-04 not reported } & $1.69 \mathrm{E}-05$ & $1.69 \mathrm{E}-05$ not reported & \\
\hline cleaner and $\mathrm{pH}$ adjuster & $4.12 \mathrm{E}-03$ & $4.12 \mathrm{E}-03$ & $1.25 \mathrm{E}-01$ & $3.37 \mathrm{E}-04$ & 3.37E-04 & $5.41 \mathrm{E}-04$ \\
\hline nutrient for yeast & $2.64 \mathrm{E}-02$ & 2.64E-02 & 2.03E-01 & $1.55 \mathrm{E}-03$ & $1.55 \mathrm{E}-03$ & $1.20 \mathrm{E}-02$ \\
\hline prevent contamination & $1.31 \mathrm{E}-05$ & \multicolumn{2}{|c|}{ 1.31E-05 not reported } & $9.99 \mathrm{E}-07$ & 9.99E-07 not reported & \\
\hline cleaner and $\mathrm{pH}$ adjuster & $1.96 \mathrm{E}-02$ & $1.96 \mathrm{E}-02$ & $1.33 \mathrm{E}-02$ & $1.13 \mathrm{E}-03$ & $1.13 \mathrm{E}-03$ & $1.01 \mathrm{E}-03$ \\
\hline denature final ethanol product for sale & $1.11 \mathrm{E}-01$ & $1.11 \mathrm{E}-01$ & $1.11 \mathrm{E}-01$ & $7.54 \mathrm{E}-03$ & 7.54E-03 & 7.54E-03 \\
\hline transport corn to ethanol plant & $5.25 \mathrm{E}-02$ & $1.08 \mathrm{E}-01$ & $1.87 \mathrm{E}-02$ & $3.84 \mathrm{E}-03$ & $7.88 \mathrm{E}-03$ & $1.28 \mathrm{E}-03$ \\
\hline & $2.70 \mathrm{E}+00$ & $2.75 \mathrm{E}+00$ & $2.87 \mathrm{E}+00$ & $1.58 \mathrm{E}-01$ & $1.62 \mathrm{E}-01$ & $1.61 \mathrm{E}-01$ \\
\hline
\end{tabular}




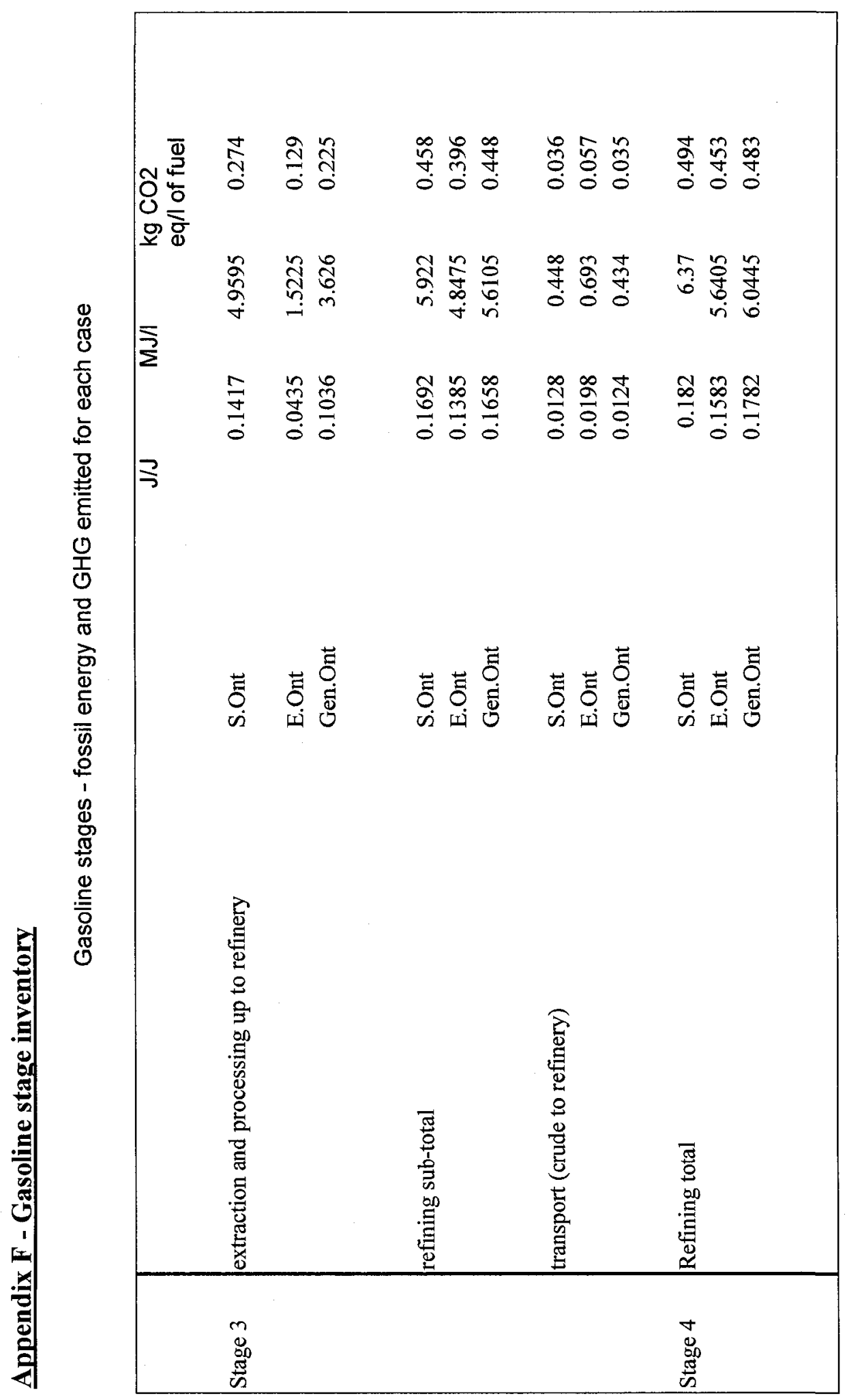


Source :

varying inputs of GHGenius $\mathrm{v} 3.11(\mathrm{y} 2007)$ and reporting $\mathrm{c} 9, \mathrm{c} 10, \mathrm{cl} 1$ of energy balance and b15, b13 and b14 from life-cycle results 2

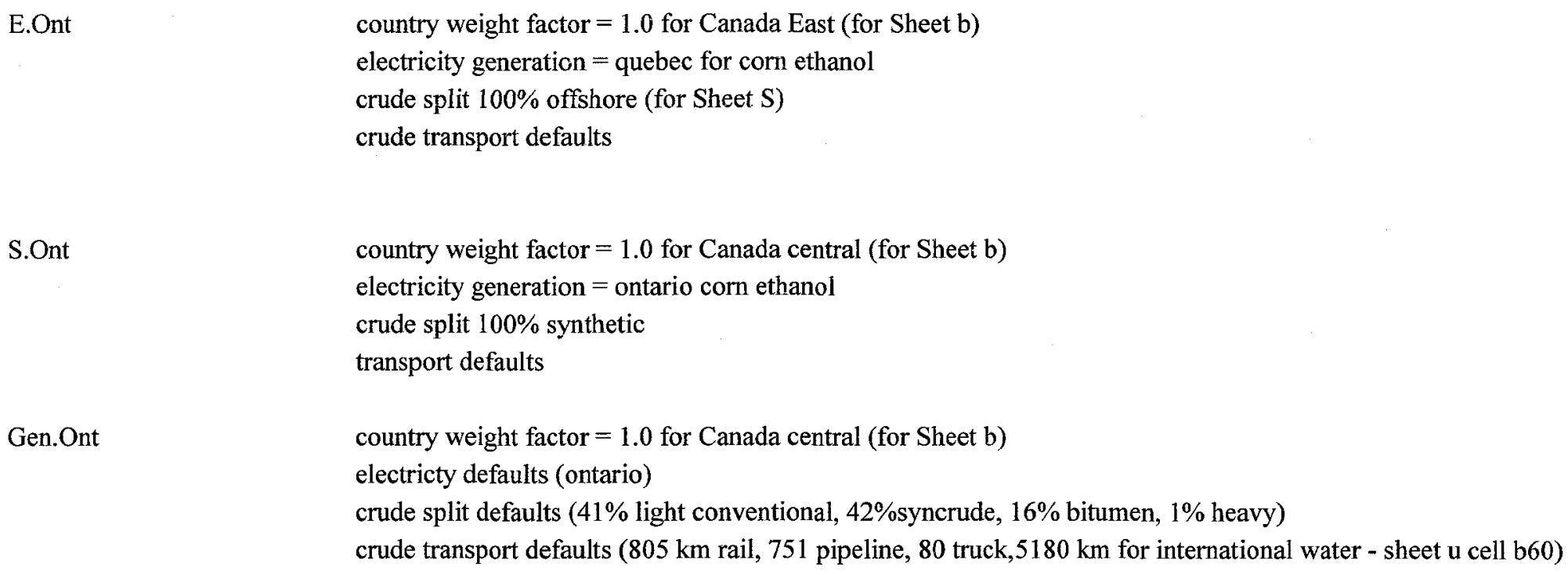

Sources in GHGenius

extraction syncrude derived from CIEDACC, 2003, Offshore oil derived from assumption of 3 x conv oil extraction and 1992 US census data, all other derived CAPP 2003 report

refineries based on Delucchi's (2003) characterization of US refineries, sector level energy use from CIEDDAC 1999- 2002 and updated by NRCan,2006 estimates 


\section{Appendix G - Blending and Storage stage inventory}

\section{Blending stage}

S.Ont St.Clair plant and blended in London Ontario with Sarnia oil refinery gasoline (120km pipeline) for sale in London area gas station ( $280 \mathrm{~km}$ round trip distance - $120 \mathrm{k}$ to london, $20 \mathrm{~km}$ to station)

E.Ont Johnstone plant and blended in Ottawa depot (from Montreal refinery ( $200 \mathrm{~km}$ pipeline) for sale in Ottawa area gas station (220 km round trip distance $-90 \mathrm{~km}$ to ottawa, $20 \mathrm{~km}$ to station)

base $\quad 225 \mathrm{~km}$ round trip ethanol to final point of sale by truck (GHGenius input sheet $\mathrm{n} 93$ ). $217 \mathrm{~km}$ pipeline and $80 \mathrm{~km}$ truck for gasoline (b98 and b99

Ont from same sheet)

notes

pipeline presence confirmed by NRCan Mike Rau

pipeline energy use not given by fuel type in GHGenius, (TAPS document suggest some pipeline pumps electricity and some turbine fuel (assume electricity for simplicity)

\begin{tabular}{|c|c|c|c|c|c|c|c|c|c|c|c|}
\hline & \multicolumn{4}{|c|}{ ethanol transport } & \multicolumn{3}{|c|}{ gasoline transport } & \multicolumn{2}{|c|}{ WII. } & \multirow{2}{*}{$\begin{array}{l}\text { MJ/func } \\
\text { unit }\end{array}$} & \multirow[b]{2}{*}{$\begin{array}{l}\text { CO2eq per } \\
\text { func unit }\end{array}$} \\
\hline & $\begin{array}{l}\text { Distance } \\
\text { ethanol }\end{array}$ & $\begin{array}{l}\text { Truck type } \\
\text { (litre capacity) }\end{array}$ & $\begin{array}{l}\text { efficiency } \\
1 / \mathrm{km}\end{array}$ & $\begin{array}{l}\text { Total diesel } \\
\text { use per litre } \\
\text { of ethanol }\end{array}$ & $\begin{array}{l}\text { Distance } \\
\text { gasoline }\end{array}$ & $\begin{array}{l}\text { pipeline energy } \\
\text { (electricity) / } 1 \\
\text { of gasoline }\end{array}$ & $\begin{array}{l}\text { Terminal } \\
\text { energy use } \\
(\mathrm{MJ}) / \mathrm{l} \text { of } \\
\text { fuel }\end{array}$ & $\begin{array}{l}\text { Total } \\
\text { Mu/ fuel }\end{array}$ & $\begin{array}{l}\text { Total con } \\
\text { equl fiel }\end{array}$ & & \\
\hline $\begin{array}{l}\text { base } \\
\text { Ont }\end{array}$ & 225 & 34000 & 0.5 & 0.003309 & 217 & 0.014973 & 0.045 & 0.216133 & 0.017039 & 1.079586 & 0.085108 \\
\hline S.Ont & 280 & 34000 & 0.5 & 0.004118 & 120 & 0.00828 & 0.045 & 0.247613 & 0.018357 & 1.236826 & 0.091691 \\
\hline E.Ont & 220 & 34000 & 0.5 & 0.003235 & 200 & 0.0138 & 0.045 & 0.21149 & 0.016527 & 1.056393 & 0.082552 \\
\hline S.Ont & g E.Ont & & & & 900 & 0.0621 & 0.045 & & & & \\
\hline
\end{tabular}

\section{FOR GASOLINE ONLY}

$\mathrm{MJ} /$ func $\quad \mathrm{GHG} /$ func unit

unit

$\begin{array}{lll}\text { G.Ont } & 0.294168 & \mathbf{0 . 0 2 7 5 8 1} \\ \text { S.Ont } & 0.261338 & \mathbf{0 . 0 2 0 3 5 9} \\ \text { E.Ont } & 0.288414 & \mathbf{0 . 0 2 6 3 1 6} \\ \text { S.Ont } & 0.525326 & \mathbf{0 . 0 7 8 4 3 6} \\ \text { using } & & \\ \text { E.Ont } & & \end{array}$




\section{Appendix H - Conversion Factors}

\begin{tabular}{|c|c|c|c|c|c|c|}
\hline & & & Conversion / Characterization factors & & & \\
\hline & & & & & & \\
\hline Input & $\begin{array}{l}\text { fossil fuel } \\
\text { factor }\end{array}$ & unit & Source and comment & $\begin{array}{l}\text { GMG } \\
\text { factor }\end{array}$ & mint & Source and comment \\
\hline \multirow[t]{2}{*}{ Diesel } & 47.20 & $\mathrm{MJ} / \mathrm{l}$ & $\begin{array}{l}\text { HHV of diesel ( } 38.37 \mathrm{MJ} / 1, \text { Annex } 4 \text { of } 1998-2004 \\
\text { National Inventory Report, EC) multiplied by } 1.23 \\
\text { (GHGenius, } 2007 \text { "energy balance" worksheet for } \\
\text { diesel) to incorporate extraction and manufacturing } \\
\text { fossil energy use }\end{array}$ & 3.45 & $\begin{array}{l}\mathrm{kg} \mathrm{CO} 2 \\
\mathrm{eq} / \mathrm{l}\end{array}$ & $\begin{array}{l}\text { total fuel cycle emission from GHGenius } \\
\text { "lifecycle results2" worksheet }\end{array}$ \\
\hline & & & & 0.073101 & \multicolumn{2}{|c|}{$\mathrm{kg} \mathrm{CO} 2 \mathrm{eq} / \mathrm{MJ}$} \\
\hline Herbicide & 244.00 & $\mathrm{MJ} / \mathrm{kg}$ & $\begin{array}{l}\text { Sheet W of GHGenius "pesticides" original data } \\
\text { source unclear }\end{array}$ & 25 & $\begin{array}{l}\mathrm{kg} \mathrm{CO} 2 \\
\mathrm{eq} / \mathrm{kg}\end{array}$ & $\begin{array}{l}\text { reported by Farell et al (2006) in "GHG } \\
\text { emissions sheet" derived from GREET } \\
1.6\end{array}$ \\
\hline Seeds & 5.81 & $\mathrm{MJ} / \mathrm{Kg}$ & $\begin{array}{l}\text { Sheet W of GHGenius (logically should be almost } \\
\text { identical to grain corn for this study which is } 1.98 \\
\mathrm{MJ} / \mathrm{kg} \text {, GHGenius attributes extra energy to } \\
\text { conservative assumption of extra transport and } \\
\text { marketing activities) }\end{array}$ & 0.363 & $\begin{array}{l}\mathrm{kg} \mathrm{CO} 2 \\
\mathrm{eq} / \mathrm{kg}\end{array}$ & Sheet X GHGenius \\
\hline Nitrogen & 44.94 & $\mathrm{MJ} / \mathrm{kg} \mathrm{N}$ & $\begin{array}{l}\text { Based on GHGenius sheet W which is based on US } \\
\text { Census data from early } 1990 \text { s and predicted } \\
\text { efficiency gains. Incorporates, mininng, processing } \\
\text { and extraction. }\end{array}$ & 2.9759 & $\begin{array}{l}\mathrm{kg} \mathrm{CO} 2 \\
\mathrm{eq} / \mathrm{kg} \text { of } \\
\mathrm{N}\end{array}$ & $\begin{array}{l}\text { calculated from GREET } 1.7 \mathrm{Ag} \text { Inputs } \\
\text { B114-116 based on mining, processes } \\
\text { sing and extraction in US }\end{array}$ \\
\hline $\begin{array}{l}\mathrm{N} 20 \text { emissions } \\
\text { from use of } \mathrm{N}\end{array}$ & n.a & n.a & n.a & 3.7 & $\begin{array}{l}\mathrm{kg} \mathrm{CO} 2 \\
\mathrm{eq} / \mathrm{kg} \mathrm{N}\end{array}$ & $\begin{array}{l}\text { Derived from N20 emission rate of } \\
0.01125 \mathrm{~kg} \mathrm{~N} 20 / \mathrm{kg} \text { of } \mathrm{N} \text { applied (and } \\
0.01125 \times 296 \text { (GWP of N2O) (emission } \\
\text { factor from GHGenius documentation } \\
\text { section } 33 \text { ) ...note IPCC value is } 0.0125 \\
\text { with evidence of being as low as } 0.008 \\
\text { (Grant et al, 2006) }\end{array}$ \\
\hline
\end{tabular}




\begin{tabular}{|c|c|c|c|c|c|c|}
\hline Potassium & 3.15 & $\begin{array}{l}\mathrm{MJ} / \mathrm{kg} \\
\mathrm{K} 20\end{array}$ & ibid & 2.775 & $\begin{array}{l}\mathrm{kg} \mathrm{CO} 2 \\
\mathrm{eq} / \mathrm{kg} \\
\mathrm{K} 20\end{array}$ & $\begin{array}{l}\text { calculated from GREET } 1.7 \mathrm{Ag} \text { Inputs } \\
\text { D1 14-116 }\end{array}$ \\
\hline Phosphate & 7.37 & $\begin{array}{l}\mathrm{MJ} / \mathrm{kg} \\
\mathrm{P} 2 \mathrm{O} 5\end{array}$ & ibid & 1.0264 & $\begin{array}{l}\mathrm{kg} \mathrm{CO} 2 \\
\mathrm{eq} / \mathrm{kg} \\
\mathrm{P} 2 \mathrm{O} 5\end{array}$ & $\begin{array}{l}\text { calculated from GREET } 1.7 \mathrm{Ag} \text { Inputs } \\
\text { C114-116 }\end{array}$ \\
\hline $\begin{array}{l}\text { farm } \\
\text { machinery - } \\
\text { tractor / } \\
\text { combine / } \\
\text { implements }\end{array}$ & 0.73 & $\begin{array}{l}\text { TJ } / \\
100,000 \$\end{array}$ & $\begin{array}{l}\text { Using EIO-LCA on-line model - an input output } \\
\text { based LCA tool derived from economic activitity of } \\
\text { the "farm machinery and equipment manufacturing" } \\
\text { sector }\end{array}$ & 62.1 & $\begin{array}{l}\text { tonnes } \\
\mathrm{CO} 2 \text { eq/ } \\
100,000 \\
\$\end{array}$ & $\begin{array}{l}\text { Using EIO-LCA on-line model - an input } \\
\text { output based LCA tool derived from } \\
\text { economic activity of the "farm machinery } \\
\text { and equipment manufacturing" sector }\end{array}$ \\
\hline natural gas & 23.06 & $\mathrm{MJ} / 1$ & $\begin{array}{l}\text { HHV of natural gas ( } 20.85 \mathrm{MJ} / \mathrm{L} \text { from Annex } 4 \text { of } \\
\text { Inventory) upstream energy is included in } \\
\text { GHGenius for CNG only and cannot be easily } \\
\text { derived from Sheet R so choosing to use the } 1.1062 \\
\text { factor for CNG from "energy balance" sheet }\end{array}$ & 0.0577 & $\begin{array}{l}\mathrm{kg} \mathrm{CO} 2 \\
\text { eq/MJ }\end{array}$ & $\begin{array}{l}\text { GHGenius sheet } N \text { includes upstream - } \\
\text { note that GREET } 1.6 \text { as reported by } \\
\text { Farell in "GHG emissions sheet" in } \\
\text { EBAMM, is } .069(20 \% \text { higher }) \text { - wide } \\
\text { use of NG means this uncertainty should } \\
\text { be modelled }\end{array}$ \\
\hline propane & 28.91 & $\mathrm{MJ} / \mathrm{l}$ & $\begin{array}{l}\mathrm{HHV} \text { of LPG is } 26.48 \mathrm{MJ} / \mathrm{L} \text { from Annex } 4 \text { of } \\
\text { Inventory) multiplied by } 1.0919 \text { of GHGenius } \\
\text { primary energy balance to incorporate upstream }\end{array}$ & 1.84 & $\mathrm{~kg} / \mathrm{l}$ & $\begin{array}{l}\text { GHGenius "lifecycle results } 2 \text { " note this } \\
\text { is for combustion in vehicle and includes } \\
\text { upstream. Not certain if combustion in } \\
\text { grain dryer different than in vehicle }\end{array}$ \\
\hline electricity & 0.92 & $\begin{array}{l}\text { btu fossil/ } \\
\text { btu } \\
\text { delivered }\end{array}$ & $\begin{array}{l}\text { Using Ontario grid values ( } 25 \% \text { coal, } 3 \% \text { NG, } 49 \% \\
\text { nuclear } 1 \% \text { biomass and } 21 \% \text { hydro) and GREET } \\
\text { "electricty' b85 fossil fuels = 33,376 (feedstock } \\
\text { production) }+881,413 \text { (fuel source) btu of fossil } \\
\text { energy per mmbtu of stationary electricty btu } \\
\text { delivered }\end{array}$ & 0.22 & $\begin{array}{l}\mathrm{kg} \mathrm{CO} 2 \\
\text { eq/Kwhr }\end{array}$ & $\begin{array}{l}\text { EC National inventory, } 2005 \text {. This does } \\
\text { not include upstream GHG emissions } \\
\text { beyond fuel combustion which could add } \\
\text { on additional } 5-10 \% \text { based on GREET } \\
1.7\end{array}$ \\
\hline
\end{tabular}




\begin{tabular}{|c|c|c|c|c|c|c|}
\hline gasoline & 44.45 & $\mathrm{MJ} / 1$ & $\begin{array}{l}\text { HHV of gasoline ( } 35 \mathrm{MJ} / \text {, Annex } 4 \text { of } 1998-2005 \\
\text { National Inventory Report, EC) multiplied by } 1.27 \\
\text { (GHGenius, } 2007 \text { "energy balance" worksheet) to } \\
\text { incorporate extraction and manufacturing primary } \\
\text { energy }\end{array}$ & 3.02 & $\begin{array}{l}\mathrm{kg} \mathrm{CO} 2 \\
\mathrm{eq} / 1\end{array}$ & $\begin{array}{l}\text { total fuel cycle emission from GHGenius } \\
\text { "lifecycle results2" worksheet }\end{array}$ \\
\hline enzyme & 90.00 & $\mathrm{MJ} / \mathrm{kg}$ & $\begin{array}{l}\text { GHGenius } 3.11 \text { sheet } \mathrm{X} \text { - further source not cited in } \\
\text { documentation }\end{array}$ & 6.66 & $\begin{array}{l}\mathrm{kg} \mathrm{CO} 2 \\
\mathrm{eq} / \mathrm{kg}\end{array}$ & $\begin{array}{l}\text { GHGenius sheet } x \text { - note that emissions } \\
\text { unit is not clear on sheet but is upstream } \\
\mathrm{CO} 2 \text { eq as checked through tracing }\end{array}$ \\
\hline $\mathrm{NaOH}$ & 9.17 & $\mathrm{MJ} / \mathrm{kg}$ & $\begin{array}{l}\text { GHGenius } 3.11 \text { sheet } \mathrm{X} \text { - further source not cited in } \\
\text { documentation }\end{array}$ & 0.7 & $\begin{array}{l}\mathrm{kg} \mathrm{CO} 2 \\
\mathrm{eq} / \mathrm{kg}\end{array}$ & GHGenius sheet $\mathrm{X}$ \\
\hline $\mathrm{H} 2 \mathrm{SO} 4$ & 2.40 & $\mathrm{MJ} / \mathrm{kg}$ & $\begin{array}{l}\text { GHGenius } 3.11 \text { sheet } \mathrm{X} \text { - further source not cited in } \\
\text { documentation }\end{array}$ & 0.197 & $\begin{array}{l}\mathrm{kg} \mathrm{CO} 2 \\
\mathrm{eq} / \mathrm{kg}\end{array}$ & GHGenius sheet $\mathrm{X}$ \\
\hline yeast & 6.32 & $\mathrm{MJ} / \mathrm{kg}$ & $\begin{array}{l}\text { GHGenius } 3.11 \text { sheet } \mathrm{X} \text { - further source not cited in } \\
\text { documentation }\end{array}$ & 0.474 & $\begin{array}{l}\mathrm{kg} \mathrm{CO} 2 \\
\mathrm{eq} / \mathrm{kg}\end{array}$ & GHGenius sheet $X$ \\
\hline antibiotics & 9.17 & $\mathrm{MJ} / \mathrm{kg}$ & $\begin{array}{l}\text { no data - since antibiotic is complex chemical } \\
\text { assume at least same as other chemicals in this data } \\
\text { set }(\mathrm{NaOH})\end{array}$ & 0.7 & $\begin{array}{l}\mathrm{kg} \mathrm{CO} 2 \\
\mathrm{eq} / \mathrm{kg}\end{array}$ & $\begin{array}{l}\text { no data - since antibiotic is complex } \\
\text { chemical assume at least same as other } \\
\text { chemicals in this data set }(\mathrm{NaOH})\end{array}$ \\
\hline ammonia & 37.00 & $\mathrm{MJ} / \mathrm{kg}$ & $\begin{array}{l}\text { GHGenius } 3.11 \text { sheet } \mathrm{X} \text { - further source not cited in } \\
\text { documentation }\end{array}$ & 2.179 & $\begin{array}{l}\mathrm{kg} \mathrm{CO} 2 \\
\mathrm{eq} / \mathrm{kg}\end{array}$ & GHGenius sheet $\mathrm{X}$ \\
\hline urea & 37.00 & $\mathrm{MJ} / \mathrm{kg}$ & assume same as urea & & & \\
\hline fuel oil & 42.50 & $\mathrm{MJ} / 1$ & Annex 4 of GHG inventory table 4.2 & 0.0852 & $\begin{array}{l}\mathrm{kg} \mathrm{co} 2 \\
\mathrm{eq} / \mathrm{MJ}\end{array}$ & Sheet $\mathrm{n}$ GHGenius \\
\hline
\end{tabular}




\section{Appendix I - Full Life cycle results and \% calculations}

Table I-1 Complete life cycle results for Ontario E5 fuel and gasoline case studies

\begin{tabular}{|c|c|c|c|c|c|c|c|c|c|c|}
\hline \multicolumn{3}{|l|}{ Case } & \multicolumn{7}{|c|}{ Life cycle stage } & \multirow[t]{2}{*}{ TOTAL } \\
\hline Case /region & Fuel & $\begin{array}{l}\text { Impact } \\
\text { category/ } \\
\text { car trip }\end{array}$ & 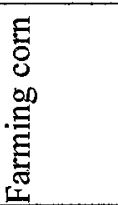 & 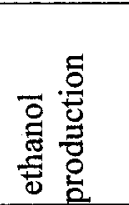 & 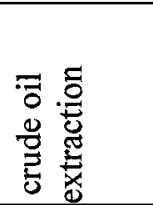 & 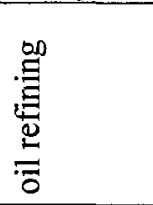 & 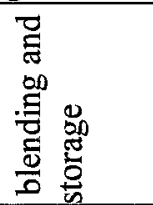 & $\frac{0}{\tilde{W}}$ & $\stackrel{\mathscr{g}}{=}$ & \\
\hline Gen.Ont & E5 & $\mathrm{MJ}$ & $\begin{array}{r}1.19 \mathrm{E}+ \\
00\end{array}$ & $\begin{array}{r}2.35 \mathrm{E}+ \\
00\end{array}$ & $1.72 \mathrm{E}+01$ & $2.87 \mathrm{E}+01$ & $1.08 \mathrm{E}+00$ & $8.65 \mathrm{E}-01$ & $1.65 \mathrm{E}+02$ & 216 \\
\hline S.Ont & E5 & $\mathrm{MJ}$ & $\begin{array}{r}9.12 \mathrm{E}- \\
01\end{array}$ & $\begin{array}{r}2.17 \mathrm{E}+ \\
00\end{array}$ & $2.35 \mathrm{E}+01$ & $3.02 \mathrm{E}+01$ & $1.24 \mathrm{E}+00$ & $8.65 \mathrm{E}-01$ & $1.65 \mathrm{E}+02$ & 224 \\
\hline E.Ont & $\mathrm{E} 5$ & $\mathrm{MJ}$ & $\begin{array}{r}1.68 \mathrm{E}+ \\
00\end{array}$ & $\begin{array}{r}2.23 \mathrm{E}+ \\
00\end{array}$ & $7.22 \mathrm{E}+00$ & $2.63 \mathrm{E}+01$ & $1.06 \mathrm{E}+00$ & $8.65 \mathrm{E}-01$ & $1.65 \mathrm{E}+02$ & 204 \\
\hline Gen.Ont & $\mathrm{E} 5$ & $\mathrm{CO}_{2} \mathrm{eq}$ & $\begin{array}{r}1.30 \mathrm{E}- \\
01\end{array}$ & $\begin{array}{r}1.09 \mathrm{E}- \\
01\end{array}$ & $1.07 \mathrm{E}+00$ & $2.29 \mathrm{E}+00$ & 8.51E-02 & $4.99 \mathrm{E}-02$ & $1.11 \mathrm{E}+01$ & 14.9 \\
\hline S.Ont & $\overline{\mathrm{E} 5}$ & $\mathrm{CO}_{2} \mathrm{eq}$ & $\begin{array}{r}9.69 \mathrm{E}- \\
02\end{array}$ & $\begin{array}{r}1.06 \mathrm{E}- \\
01\end{array}$ & $1.30 \mathrm{E}+00$ & $2.34 \mathrm{E}+00$ & $9.17 \mathrm{E}-02$ & $4.99 \mathrm{E}-02$ & $1.11 \mathrm{E}+01$ & 15.1 \\
\hline E.Ont & $\mathrm{E} 5$ & $\mathrm{CO}_{2} \mathrm{eq}$ & $\begin{array}{r}1.62 \mathrm{E}- \\
01\end{array}$ & $\begin{array}{r}1.10 \mathrm{E}- \\
01\end{array}$ & $6.12 \mathrm{E}-01$ & $2.15 \mathrm{E}+00$ & $8.26 \mathrm{E}-02$ & $4.99 \mathrm{E}-02$ & $1.11 \mathrm{E}+01$ & 14.3 \\
\hline Gen.Ont & Gasoline & $\mathrm{MJ}$ & N/A & $\mathrm{N} / \mathrm{A}$ & $1.78 \mathrm{E}+01$ & $2.96 \mathrm{E}+01$ & $2.94 \mathrm{E}-01$ & $8.65 \mathrm{E}-01$ & $1.70 \mathrm{E}+02$ & 219 \\
\hline S.Ont & Gasoline & $\mathrm{MJ}$ & N/A & N/A & $2.43 \mathrm{E}+01$ & $3.12 \mathrm{E}+01$ & $2.61 \mathrm{E}-01$ & $8.65 \mathrm{E}-01$ & $1.70 \mathrm{E}+02$ & 227 \\
\hline E.Ont & Gasoline & $\mathrm{MJ}$ & $\mathrm{N} / \mathrm{A}$ & N/A & $7.47 \mathrm{E}+00$ & $2.72 \mathrm{E}+01$ & $2.88 \mathrm{E}-01$ & $8.65 \mathrm{E}-01$ & $1.70 \mathrm{E}+02$ & 206 \\
\hline Gen.Ont & gasoline & $\mathrm{CO}_{2} \mathrm{eq}$ & $\mathrm{N} / \mathrm{A}$ & N/A & $1.10 \mathrm{E}+00$ & $2.37 \mathrm{E}+00$ & $2.76 \mathrm{E}-02$ & $4.99 \mathrm{E}-02$ & $1.15 \mathrm{E}+01$ & 15.0 \\
\hline S.Ont & gasoline & $\mathrm{CO}_{2} \mathrm{eq}$ & N/A & N/A & $1.34 \mathrm{E}+00$ & $2.42 \mathrm{E}+00$ & $2.04 \mathrm{E}-02$ & $4.99 \mathrm{E}-02$ & $1.15 \mathrm{E}+01$ & 15.3 \\
\hline E.Ont & gasoline & $\mathrm{CO}_{2} \mathrm{eq}$ & $\mathrm{N} / \mathrm{A}$ & N/A & $6.33 \mathrm{E}-01$ & $2.22 \mathrm{E}+00$ & $2.63 \mathrm{E}-02$ & $4.99 \mathrm{E}-02$ & $1.15 \mathrm{E}+01$ & $\overline{14.4}$ \\
\hline
\end{tabular}


Table I.2 - Page 94 - Trucking S.Ont Corn to E.Ont (add $1800 \mathrm{~km}$ return truck distance to stage 2 in E.Ont)

FF use (MJ/ $45 \mathrm{~km}$ car trip)

\begin{tabular}{lrrr} 
& \multicolumn{1}{c}{ stage 1 } & \multicolumn{2}{c}{ stage 2 } \\
S.Ont E5 & 0.91 & 2.17 & 3.09 \\
E.Ont E5 & 1.68 & 2.23 & 3.91 \\
\% difference & $-84.09 \%$ & $-2.54 \%$ & $-26.65 \%$ \\
& & & \\
S.Ont corn in E.Ont & 0.91 & 2.80 & 3.71 \\
E5 & & & \\
E.Ont E5 & 1.68 & 2.23 & 3.91 \\
\% difference & $-84.09 \%$ & $20.30 \%$ & $-5.38 \%$
\end{tabular}

GHG (kg CO2 eq/45 km trip)

$\begin{array}{lrrr} & \text { stage 1 } & \text { stage 2 } & \text { Total } \\ \text { S.Ont E5 } & 0.10 & 0.11 & 0.20 \\ \text { E.Ont E5 } & 0.16 & 0.11 & 0.27 \\ \text { \% difference } & -67.30 \% & -3.83 \% & -34.19 \% \\ & & & \\ \text { S.Ont corn in } & 0.10 & 0.15 & 0.25 \\ \text { E.Ont E5 } & & & \\ \text { E.Ont E5 } & 0.16 & 0.11 & 0.27 \\ \text { \% difference } & -67.30 \% & 27.45 \% & -9.55 \%\end{array}$

Table I.3 - Page 98 - Margin of error between Gen.Ont and regional cases for stage 1

FF use (MJ/ $45 \mathrm{~km}$ car trip)

stage 1

Gen. Ont E5

S.Ont E5

$\%$ difference

Gen. Ont E5

E.Ont E5

$\%$ difference

1.19
0.91
$23.09 \%$

1.19
1.68
$-41.58 \%$

$$
0.91
$$$$
1.19
$$$$
-41.58 \%
$$

GHG (kg CO2 eq/45 km trip)

$\begin{array}{lr} & \text { stage 1 } \\ \text { Gen.Ont } & 0.13 \\ \text { S.Ont E5 } & 0.10 \\ \text { \% difference } & 25.30 \% \\ & \\ \text { Gen.Ont } & 0.13 \\ \text { E.Ont E5 } & 0.16 \\ \text { \% difference } & -24.97 \%\end{array}$


Table 1.4 - Page 103 - Margin of error between Gen.Ont and regional cases for stage 3

FF use (MJ/ $45 \mathrm{~km}$ car trip)

$\begin{array}{lr} & \text { stage 3 } \\ \text { Gen. Ont E5 } & 17.21 \\ \text { S.Ont E5 } & 23.53 \\ \text { \% difference } & -36.78 \% \\ & \\ \text { Gen. Ont E5 } & 17.21 \\ \text { E.Ont E5 } & 7.22 \\ \text { \% difference } & 58.01 \%\end{array}$

\section{GHG (kg CO2 eq/45 km trip)}

\begin{tabular}{lr} 
& \multicolumn{2}{c}{ stage 3} \\
Gen.Ont & 1.07 \\
S.Ont E5 & 1.30 \\
\% difference & $-21.78 \%$ \\
& \\
Gen.Ont & 1.07 \\
E.Ont E5 & 0.61 \\
\% difference & $42.67 \%$
\end{tabular}

Table I.5 - Page 108 - Transporting E.Ont gasoline by pipeline to S.Ont

\begin{tabular}{|c|c|c|c|c|}
\hline \multirow[b]{3}{*}{ E.Ont gas } & \multicolumn{4}{|c|}{ GHG (kg CO2 eq/45 km trip) } \\
\hline & stage 3 & ge 4 & stage 5 & total stage $3-7$ \\
\hline & 0.63 & 2.22 & 0.03 & 14.44 \\
\hline S.Ont gas & 1.34 & 2.42 & 0.02 & 15.33 \\
\hline$\%$ difference & $-112.40 \%$ & $-9.05 \%$ & $22.64 \%$ & $-6.29 \%$ \\
\hline $\begin{array}{l}\text { S.Ont gas from } \\
\text { E.Ont }\end{array}$ & 0.63 & 2.25 & 0.08 & 14.50 \\
\hline S.Ont gas & 1.34 & 2.42 & 0.02 & 15.33 \\
\hline$\%$ difference & $-112.40 \%$ & $7.86 \%$ & $74.04 \%$ & $-5.72 \%$ \\
\hline
\end{tabular}

